\title{
The Relationship between Oil Prices and US Dollar Exchange Rates in Short and Long Scales
}

\author{
Mostafa Hashemi
}

Follow this and additional works at: https://researchrepository.wvu.edu/etd

\section{Recommended Citation}

Hashemi, Mostafa, "The Relationship between Oil Prices and US Dollar Exchange Rates in Short and Long Scales" (2017). Graduate Theses, Dissertations, and Problem Reports. 5779.

https://researchrepository.wvu.edu/etd/5779

This Thesis is protected by copyright and/or related rights. It has been brought to you by the The Research Repository @ WVU with permission from the rights-holder(s). You are free to use this Thesis in any way that is permitted by the copyright and related rights legislation that applies to your use. For other uses you must obtain permission from the rights-holder(s) directly, unless additional rights are indicated by a Creative Commons license in the record and/ or on the work itself. This Thesis has been accepted for inclusion in WVU Graduate Theses, Dissertations, and Problem Reports collection by an authorized administrator of The Research Repository @ WVU. For more information, please contact researchrepository@mail.wvu.edu. 


\title{
The Relationship between Oil Prices and US Dollar Exchange Rates in Short and Long Scales
}

\author{
Mostafa Hashemi
}

Thesis submitted

to the Davis College of Agriculture, Natural Resources, and Design

at West Virginia University

in partial fulfillment of the requirements for the degree of

Master of Science in

Agricultural and Resource Economics

Xiaoli Liao Etienne, Ph.D, Chair

Alan Collins, Ph.D.

Hodjat Ghadimi, Ph.D.

Division of Resource Economics and Management

Morgantown, West Virginia

2017

Keywords: Oil Prices, Exchange Rates, Causality, Cointegration

Copyright 2017 Mostafa Hashemi 


\section{ABSTRACT \\ The Relationship Between Oil Prices and US Dollar Exchange Rates \\ in Short and Long Scales}

\section{Mostafa Hashemi}

The purpose of this study is to revisit the relationship between US dollar exchange rates and crude oil prices in the post-2000 era, when both oil prices and USD exchange rates experienced record-high volatility. Specifically, I aim to answer: (1) do oil prices drive US dollar exchange rates or vice versa, (2) are oil prices and US dollar exchange rates integrated in the long-run, and (3) are the conflicting results found in previous studies on the relationship between the two due to the use of different frequencies of data (e.g. daily, weekly, and monthly). To answer these questions, I applied time series procedures, in particular Granger causality tests based on vector auto-regressive and vector error correction models, on daily, weekly, and monthly oil prices and US dollar exchange rates against a variety of foreign currencies (including both oil-importing and oil-exporting countries) from January 2000 to September 2017. Results from the analyses suggest that the relationship between oil prices and exchange rates does differ at daily, weekly, and monthly frequencies. In daily frequency, AUD/USD, CAD/USD, EUR/USD, and NOK/USD are cointegrated with oil prices while no long-run relationship has been found between JPY/USD, MXN/USD, and GBP/USD with oil prices. The pattern of cointegrated and non-cointegrated variables remained the same in weekly period. However, in monthly period, NOK/USD is not cointegrated with oil prices highlighting the effect of different time frequencies on the relationship between US dollar exchange rates and oil prices. The result of this study provides evidence that in all cointegrated cases, when deviations to the long-run equilibrium occur, the US dollar exchange rates corrected its deviation by adjusting back the oil prices to their equilibrium. Furthermore, the type of causality varies in different time frequencies. In daily and monthly frequencies, unidirectional, bidirectional and no causality have been detected while in weekly frequency, all short-run relationships are independent from each other. Therefore, as opposed to daily and monthly frequencies, there is no possibility of predictability in weekly frequency 


\section{ACKNOWLEDGMENTS}

I would like to thank my advisor Dr. Etienne for her continuous guidance and support during my research. I also thank my committee members, Dr. Collins and Dr. Ghadimi, for their helpful comments to my thesis. Additionally, I am indebted to Dr. D'Souza for his consistent help during my M.S. program. I also want to show appreciation to my beautiful wife, Raika, for all her support and encouragement. 


\section{TABLE OF CONTENTS}

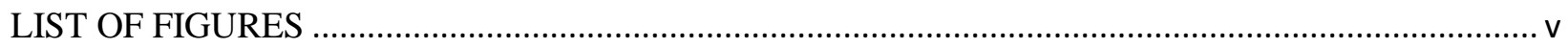

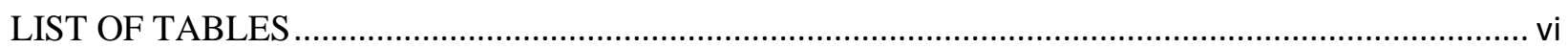

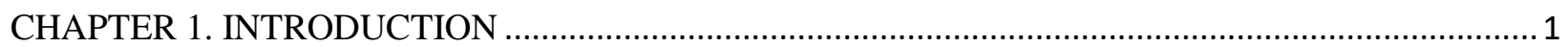

CHAPTER 2. THEORETICAL RELATIONSHIPS BETWEEN OIL PRICES AND U.S. EXCHANGE

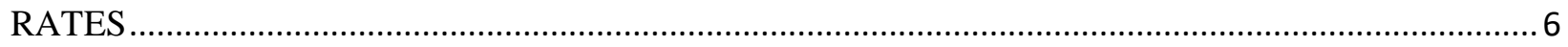

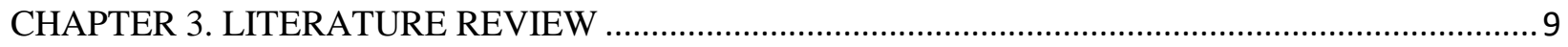

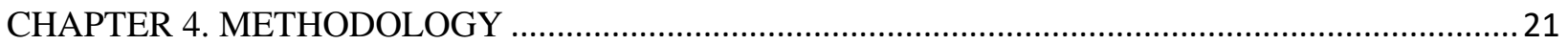

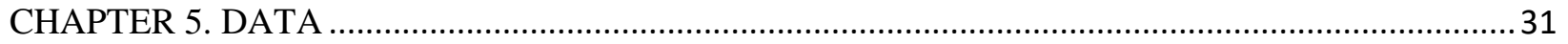

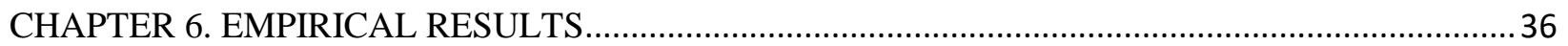

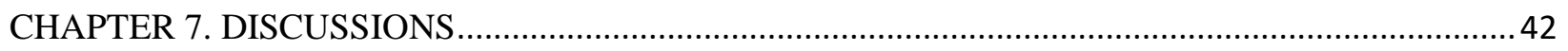

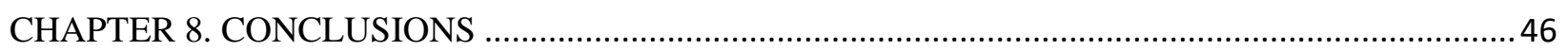

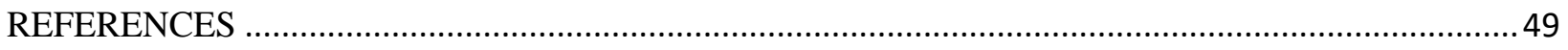

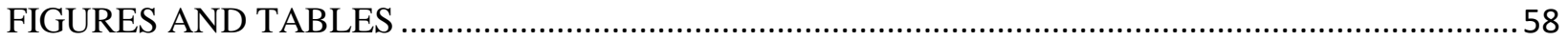




\section{LIST OF FIGURES}

Figure 1: Daily Crude oil spot prices (WTI) and major US dollar exchange rates ( ${ }^{\text {st }}$ January

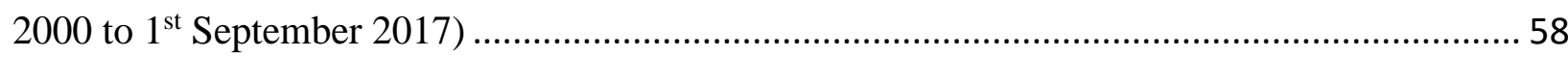

Figure 2: Weekly Crude oil spot prices (WTI) and major US dollar exchange rates $\left(1^{\text {st }}\right.$ January 2000 to $1^{\text {st }}$ September 2017)

Figure 3: Monthly Crude oil spot prices (WTI) and major US dollar exchange rates ( $1^{\text {st }}$ January

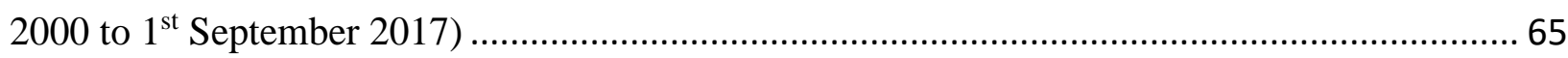

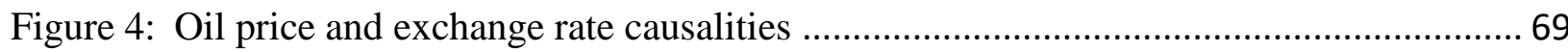

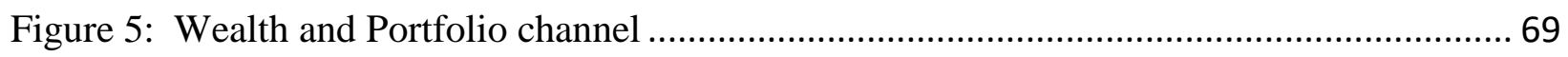

Figure 6: Supply and demand of oil and decline in US dollar ............................................. 70 


\section{LIST OF TABLES}

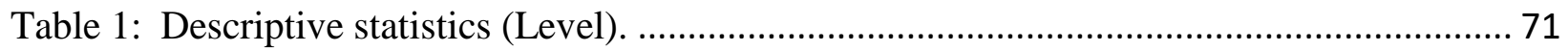

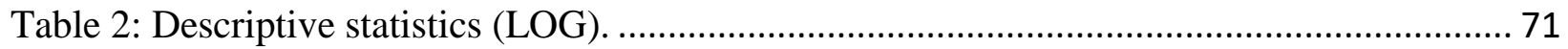

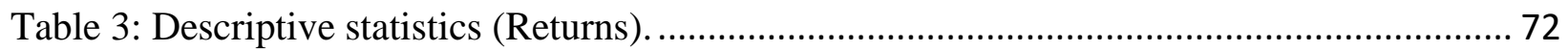

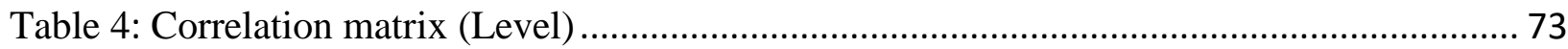

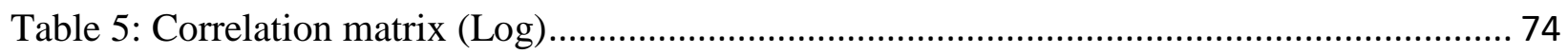

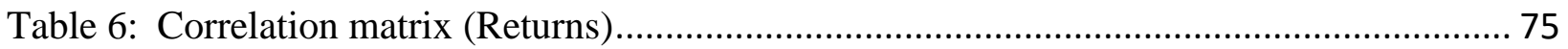

Table 7: Correlation matrix (Returns) between oil prices and USD exchange rates for different

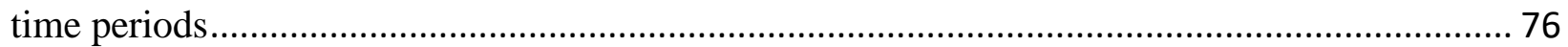

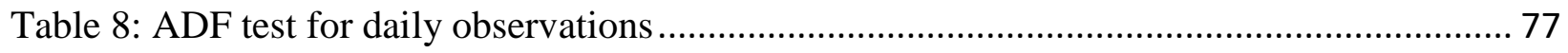

Table 9: ADF test for weekly observations ............................................................................ 78

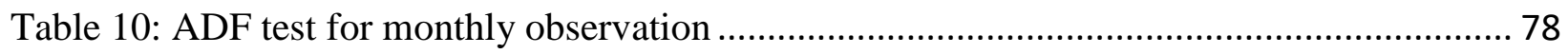

Table 11: Johansen tests for cointegration (daily observations from 2000 to 2017) .................... 79

Table 12: Johansen tests for cointegration (weekly observations from 2000 to 2017) ................. 79

Table 13: Johansen tests for cointegration (monthly observations from 2000 to 2017)............... 79

Table 14: Granger causality test results for daily JPY/USD, MXN/USD, and UK/USD with oil

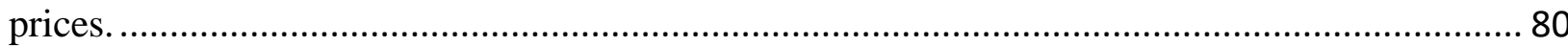

Table 15: Granger causality test results for weekly JPY/USD, MXN/USD, and UK/USD with oil

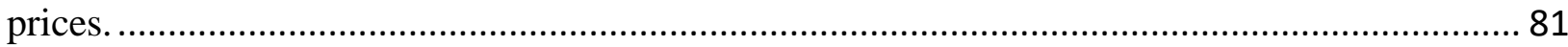

Table 16: Granger causality test results for monthly JPY/USD, MXN/USD, NOK/USD, and

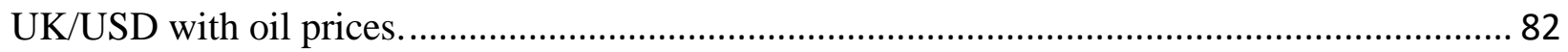

Table 17: Granger causality and long-run test results for daily AUD/USD, CAD/USD,

EUR/USD and NOK/USD with oil prices.

Table 18: Granger causality and long-run test results for weekly AUD/USD, CAD/USD,

EUR/USD and NOK/USD with oil prices.

Table 19: Granger causality and long-run test results for monthly AUD/USD, CAD/USD, and

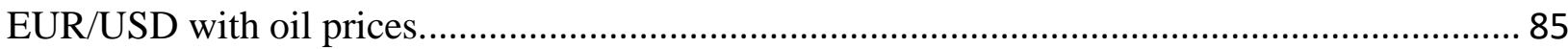

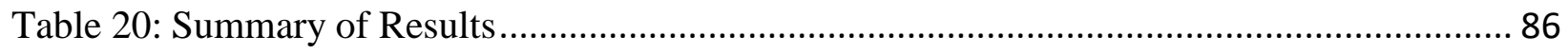




\section{CHAPTER 1. INTRODUCTION}

In the international market, crude oil is priced in U.S. dollars, a phenomenon commonly referred to as petrodollars. This fact has important implications for both oil importers and exporters and the currencies used in these countries. Oil importers who do not use US dollars as their currencies must in effect, obtain US dollars to purchase oil, while oil exporters who use non-US dollar currencies must, effectively convert US dollars to their domestic currencies from oil sales (Trehan, 1986). Therefore, a change in the US dollar exchange rates may affect the price an oil importer would pay and an oil exporter would receive in their domestic currencies.

The relationship between oil prices and US dollar exchange rates is an important topic for economists, politicians, scholars, policymakers, and even journalists, and has been under continuous scrutiny since the establishment of petrodollars in the 1970s. The question of what would happen to the price of oil in case of a salient US dollar appreciation can come to the minds of many experts from oil-exporting countries, due to the relationship between oil prices and their revenues, and many market participants from oil-importing countries, due to the relationship between oil prices and their costs. Conversely, policymakers and researchers may also be interested in the effect of oil prices on exchange rates, as changes in oil prices may lead to fluctuations in the currency values of both oil-importing and oil-exporting countries through the terms of trade (Amano \& Norden, 1998) and wealth effects (Krugman, 1983).

Oil is a momentous strategic resource. All key macroeconomic variables for major countries, including the gross domestic product (GDP), the unemployment rate, and the inflation rate are sensitive to energy price changes, oil prices in particular. Hamilton (1983) noted that with a lag of about three-fourth of a year (i.e., nine months), almost all post World War II US depressions had been predated by a dramatic shock in oil prices. However, he emphasized that 
without controling for other variables, this lead-lag relationship should not be interpreted as oil shocks causing those depressions. By connecting oil prices and the main US macroeconomic variables, Camarero \& Tamarit (2002) extend Hamilton's analysis (1993) and find that the recessions in the 1970s and 1980s can be attributed, at least in part, to oil price shocks.

Oil prices are profoundly influenced by geopolitics, demand and supply conditions, seasonal factors, financial market fluctuations, military conflicts, and international organizations such as OPEC (Yousefi \& Wirjanto, 2004). As a simple rule of thumb, increasing demand for, and decreasing supply of, crude oil would lead to a rise in oil prices (Golub, 1983). Emerging economies such as China and India have had a major role in triggering oil demand over the past two decades (Basher, Haug, \& Sadorsky, 2012; Huang \& Guo, 2007). The rate of real GDP growth in these countries was on average $3.4 \%$ in 1980 , which has increased to $8.6 \%$ in $2017^{1}$. Since oil is denominated in US dollars, fluctuations in USD exchange rates can greatly influence the demand of oil from these emerging economies (as well as other developed oil importers), affecting oil prices. An appreciation in US dollar exchange rates, for instance, may decrease the demand for oil and depress oil prices. A weak US dollar (as in 2006-2008), on the other hand, suggests that oil importers other than the United States are paying less for oil, hence a greater demand from these countries that could eventually drive up oil prices.

Oil prices have experienced a massive volatility over the past two decades. Using West Texas Intermediate (WTI) as the benchmark, Figure 1 shows that from 2002 to 2008 there was a huge jump in oil prices, rising from about $\$ 29$ per barrel to $\$ 146$ per barrel. Reboredo, Riveracastro, \& Zebende (2014) asserted that due to the importance of oil in the economy, continuous fluctuations in oil prices not only affect key economic and financial factors (e.g. exchange rates),

\footnotetext{
${ }^{1}$ http://www.imf.org/external/datamapper/NGDP_RPCH@WEO/OEMDC/ADVEC/WEOWORLD.
} 
but also alter their relationships to oil prices. Figure 1 suggests that the value of US dollar against other major currencies (especially those of the oil exporters) experienced a noticeable decline around the same timeframe (2002-2008). In fact, a decline in US dollar exchange rates can be detected before almost every rise in oil prices. Over the past few years, however, oil prices have plummeted, fluctuating around $\$ 50$ by the end of 2016. US dollars, on the other hand, have appreciated. The correspondence between high (low) oil prices and low (high) US dollar exchange rates should certainly not be viewed as a causal relationship without a thorough investigation of the dependence between the two variables. Visual inspections of the plots between oil prices and US dollar exchange rates (Figures 1-3), at the minimum, suggest that these two are likely to be negatively correlated.

The empirical interrelationship between oil prices and US dollar exchange rates has been well analyzed in the literature using a vareity of econometric techniques, such as Granger causality test, Engle Granger causality, copula, GARCH, cointegration analysis, the vector autoregressive model (VAR), and the vector error correction model (VECM). Almost all previous studies have found a strong relationship between oil prices and US dollar exchange rates in the long-run. However, in the short-run, the results are more complexed — evidence of bidirectional causality, unidirectional causality from either oil prices to the US dollar exchange rates or vice versa, and even no causality (i.e., independency) have been suggested for the relationship between oil prices and US dollar exchange rates (Basher et al., 2012; Beckmann \& Czudaj, 2013; Camarero \& Tamarit, 2002). Empirical methods employed, sample periods considered, and countries used (i.e., oil-importing or oil-exporting countries) are often identified as some possible contributors to the conflicting results found in the literature. Another possible factor is the frequency of data examined 
in the analyses. Indeed, various frequencies of data, including yearly, quarterly, monthly, weekly, daily, and sometimes even intra-day data were used in previous studies.

Although the link between oil prices and exchange rates has been extensively examined in the literature, there is much left to be explored due to the importance of this relationship, the rapid changes occurring in the market, and the lack of consensus on their relationships in the literature (Amano \& Norden, 1998). The question becomes even more important in an era where both oil prices and US dollar exchange rates are experiencing massive volatility, and emerging economies are becoming increasingly more oil-dependent. During the last three decades, oil prices were considerably more volatile compared to other energy products, which have increased global economic uncertainty and contributed to the recent worldwide economic slow-down (Plourde \& Watkins, 1998). Meanwhile, US dollar exchange rates were similarly unstable, increasing the risks in oil market, which in turn can lead to global economic uncertainty. A clear understanding of the relationship between oil prices and exchange rates is vital for policymakers to design effective policies toward reducing domestic energy price volatility, improving international competitiveness, and promoting economic growth. For investors, a thorough understanding of the relationship between oil prices and exchange rates in the volatile market would suggest enormous opportunities to gain high revenues and maximize economic profits (Aloui, Safouane, Aïssa, \& Khuong, 2013).

The purpose of this thesis is to revisit the relationship between US dollar exchange rates and crude oil prices in the post-2000 era when both experienced record-high volatility. Specifically, I aim to answer: (1) do oil prices drive US dollar exchange rates or vice versa, (2) are oil prices and US dollar exchange rates integrated in the long-run, (3) are the conflicting results found in previous studies on the relationship between the two due to the use of different data 
frequencies (e.g. daily, weekly, and monthly). To answer these questions, I apply time series procedures, in particular Granger causality tests based on vector auto-regressive and vector error correction models, on daily, weekly, and monthly oil prices and US dollar exchange rates against a variety of foreign currencies (including both oil-importing and oil-exporting countries) from January 2000 to September 2017. This study differs from the existing literature in a number of ways. First, I include a recent sample period that incorporates sub-periods of both high and low oil prices, as well as times when US dollar exchange rates experienced rapid appreciation and depreciation. Second, I consider different data frequencies to shed light on the source of conflicting results found in previous studies. Third, I analyze both long- and short-run relationships between oil prices and US dollar exchange rates. Finally, to determine whether the relationship between the two differ by the countries considered, I include the US dollar exchange rates against currencies from a variety of countries, including both oil importers and exporters.

Results from the analyses suggest that the relationship between oil prices and exchange rates does differ at daily, weekly, and monthly frequencies. In daily frequency, AUD/USD, CAD/USD, EUR/USD, and NOK/USD are cointegrated with oil prices while no long-run relationship has been found between JPY/USD, MXN/USD, and GBP/USD with oil prices. The pattern of cointegrated and non-cointegrated variables remained the same in weekly period. However, in monthly period, NOK/USD is not cointegrated with oil prices highlighting the effect of different time frequencies on the relationship between US dollar exchange rates and oil prices. The result of this study provides evidence that in all cointegrated cases, when deviations to the long-run equilibrium occur, the US dollar exchange rates corrected its deviation by adjusting back the oil prices to their equilibrium. 


\section{CHAPTER 2. THEORETICAL RELATIONSHIPS BETWEEN OIL PRICES AND U.S. EXCHANGE RATES}

Oil price changes can affect US dollar exchange rates in a number of ways. The first is through the terms of trade, introduced by Amano \& Norden(1998), as shown in Figure 4. The underlying idea of this theory is that oil prices can affect the sectors that directly influence the exchange rate. Consider a two-country, two-sector world consisting of tradable and non-tradable goods. Non-tradable goods such as labor and real estates may not be exported or imported, and can be used only based on local demand and supply balances, while the tradable goods can be either exported or imported in the international market (e.g., oil, cell phone, and steel industry).

Based on this theory, if in country A the non-tradable sector is more energy intensive than the tradable one, its tradeable sector will have a higher price than in country $\mathrm{B}$, leading to appreciation in the non-tradable sector, and hence a higher real exchange rate for country A (Chen \& Chen, 2007; Habib, Butzer, \& Stracca, 2016). If the price of oil changes, then the nominal exchange rate, which is linked to inflation via purchasing power parity (PPP), will also change. For instance, a rise in oil prices will lead to inflation, and hence a depreciation of the tradable sector for countries highly dependent on oil, resulting in a deterioration of the trade balance and subsequently a depreciation of its currency. By some estimates, variations in oil prices can explain most of the variability in the terms of trade (Backus \& Crucini, 2000).

A classic example under this theory is the Dutch disease that occurred in the Netherlands after the discovery of the Groningen natural gas field in 1959. In the context of present analysis, the extra revenue from oil price increases, or equivalently the discovery of new oil reserves, would result in an appreciation of demand for non-tradable goods and an increase in the prices of nontradable goods, eventually lead to an appreciation in real exchange rates compared to other nations 
(M. Corden, 1984). Additionally, as a result of the currency appreciation, the country's other exports would become more expensive while other country's imports become cheaper, eventually making the domestic exporting sector less competitive in the international market.

Figure 5 demonstrates the second theory, the portfolio and wealth channel, first introduced by Krugman (1983). It generally focuses on the wealth transfer from oil-importing countries (such as the USA and Japan) to oil-exporting countries (such as OPEC and Mexico) in case of an increase in oil prices. Based on this theory, in the short-run, an increase in oil prices will lead to an appreciation in oil-exporting countries' exchange rates through transferring wealth (in US dollar) from oil-importers to the oil-exporters (Beckmann \& Czudaj, 2013). However, more accumulated wealth for oil-exporting countries such as OPEC means purchasing more products form industrial countries such as the United States which could possibly lead to an appreciation of US dollar in the medium and long run (Bénassy-Quéré, Mignon, \& Penot, 2007). The net effect of an oil price change on the US dollar exchange rate then is determined by the dependence of US on imported oil relative to the amount of US products exported to oil-exporting countries and these countries preferences for the US products (Coudert, Mignon, \& Penot, 2007).

On the other hand, US dollar exchange rates can also affect oil prices. Figure 6 demonstrates the effect of a depreciation of US dollars on the supply and demand of oil. Since oil is denominated by US dollars, oil importers must in effect buy US dollar in order to purchase crude oil, and oil exporters essentially have to convert US dollars to their domestic currencies for economic activities. In Figure 6, assume that $\mathrm{D}_{0}$ and $\mathrm{S}_{0}$ are demand for oil by oil importers, and supply for oil by oil producers, respectively. Assuming a fixed price for oil prices (in USD), a fall in the value of US dollars means cheaper oil for oil importers except the US, leading to a higher 
demand for oil. In the graph, this means that the demand curve will shift to the right from $\mathrm{D}_{0}$ to $\mathrm{D}_{1}$, resulting in higher equilibrium prices for oil (Trehan, 1986).

Meanwhile, on the supply side, a cheaper crude oil due to lower US dollar exchange rates means that oil producers will no longer produce at the equilibrium level prior to changes in the exchange rate. The supply curve in Figure 6 will shift to the left from $S_{0}$ to $S_{1}$. A right shift in the demand curve and a left shift in the supply curve suggests that the equilibrium price of oil (in US dollars) will increase from $\mathrm{P}_{0}$ to $\mathrm{P}_{1}$. Therefore, US dollar exchange rates negatively affect oil prices, as shown in Figure 6.

In summary, the importance of the relationship between US dollar exchange rates and oil prices presents itself through the consequences of their volatilities on the economy. The volatility of the US dollar exchange rates shows itself in an instability of international purchasing power of oil exporting countries (Zhang, Fan, Tsai, \& Wei, 2008). Falling and rising in oil prices provides new opportunities for both investors and speculators in oil market. A large quantity of dollars will flow into the market due to weakness in USD which will leave the market when the value of USD increases. On the other hand, the volatility in oil prices shows itself in the amount of wealth transferring from oil-importers to oil-exporters. The effect on fluctuation in their oil revenues reflects on their economies (Yousefi \& Wirjanto, 2004). 


\section{CHAPTER 3. LITERATURE REVIEW}

An abundance of papers have investigated the interfaces amongst miscellaneous oil markets (Hammoudeh, Li, \& Jeon, 2003; Lin \& Tamvakis, 2001; Sari, Hammoudeh, \& Soytas, 2010; Zhang et al., 2008). Also, a rich body of literature has examined the relationship between oil markets and financial markets (Arouri \& Nguyen, 2010; Basher et al., 2012; Basher, Haug, \& Sadorsky, 2016; Cifarelli \& Paladino, 2010; Dauvin, 2014; Fayyad \& Daly, 2011; Hammoudeh \& Aleisa, 2004; Park \& Ratti, 2008).

However, the interaction between the US dollar exchange rate and the international crude oil market, despite its importance for many economic and financial applications, has not received enough attention compared to the aforementioned topics. As discussed in the previous section, there exists some theoretical support for the casual relationship between oil prices and the US dollar exchange rates. Consistent with the theoretical model, a reciprocating impact has been found in the empirical literature concerning the US dollar exchange rates and the oil price. In general, most studies, regardless of the empirical models used, have found similar results. Their findings indicate that there is a negative correlation between oil prices and the US dollar exchange rates. For example, Yousefi \& Wirjanto (2004), by using Hansen's GMM model, and Cifarelli \& Paladino (2010), by using multivariate CCC GARCH-M model, both have found an inverse relationship between those aforementioned variables.

Studies examining the relationship between the real exchange rates and the real oil prices can be divided into two categories: 1) those investigating the impact of oil price on the real exchange rates such as Akram (2009), Amano \& Norden (1998), Camarero \& Tamarit (2002), and Narayan, Narayan, \& Prasad, (2008), and 2) those looking at the effects of the real exchange rates 
on oil prices (e.g., Indjehagopian, Lantz, \& Simon (2000), Krichene (2005), Reboredo, Riveracastro, \& Zebende (2014), and Wu, Chung, \& Chang (2012)).

A large number of studies noted the role of oil price as a non-monetary shock to explain the instability of exchange rates (Akram, 2009; Narayan et al., 2008). Gisser \& Goodwin (1986) confirmed the real and inflationary effects of the real price of oil. Phelps (1994) found a relationship between oil prices and the natural rate of unemployment in the US. Keane \& Prasad (1996) noted the relationship between oil price shocks and a decline in wages in the US. Carruth, Hooker, \& Oswald (1998) associated oil price and interest rate to the rate of postwar loss of jobs.

Starting with the first category, Amano \& Norden (1998) tracked whether fluctuations in the US real effective exchange rates, were able to be explained by the real oil prices. They used monthly observations of the real effective (i.e. trade-weighted) value of the US dollar against 15 other currencies and concluded that US oil prices and US real effective exchange rates are cointegrated. In addition, oil price shocks should be considered as the most important source of continuous real exchange rate fluctuations. Moreover, their results suggested that fluctuations in US dollar movement cannot change the trend of the oil prices. This is similar to the finding of Hamilton (1983) who noted "oil price shocks are exogenous to the real exchange rates."

Using panel cointegration techniques and structural monetary model of Meese \& Rogoff (1988), Camarero \& Tamarit (2002) found that real interest rate differentials (as a monetary policy) and the real oil price are two main long-term factors explaining the real exchange rates of Spanish peseta. However, in the countries that are not as oil-dependent as Spain, the role of real oil price is more substantial compared to the countries that were not as successful as Spain to substitute oil by other energy resources. The effects of monetary policy approach regarding the effect of oil prices and real interest rates on real exchange rates can be understood in three step. First, it is 
found that energy prices and macroeconomy are related to each other, and almost after each main oil shock, a recession can be expected (Hamilton, 1983). Second, there is a link between real exchange rates and oil prices. Third, exchange rates and interest rate differentials are related together (Campbell \& Clarida, 1987; Clarida \& Gali, 1994; Meese \& Rogoff, 1988).

In addition, Perron (1989) found that OPEC agreed to increase oil prices for the first time in 1973 and it led to some major structural breaks in US dollar exchange rates. Chaudhuri \& Daniel (1998) used monthly real exchange rates data for 16 OECD (Organization for Economic Cooperation and Development) countries and UAE oil price benchmark. They utilized cointegration and causality tests and concluded that that the non-stationary behavior of real oil price resulted in the non-stationary behavior of US dollar exchange rates. Consistently, Akram (2004) explored the non-linear relationship between oil prices and the Norwegian exchange rate, find a dynamic inverse relationship between oil prices and the Norwegian exchange rate. This relationship became much stronger when the price of oil decreased (falling less than 14 dollars per barrel). The author also found that different levels and trends of oil prices were the two important factors in shaping the nature of this relationship. Similarly, Throop (1993) used an error correction model and considered productivity growth, budget deficits, and the real price of oil as three major shocks on the US dollar fluctuations. He found a positive relationship between oil price and US dollar.

Huang \& Guo (2007) used a quadruplet-dimensional version of vector auto-regression model and decomposed shocks into four categories. They identified that as oil price increases, in long-run, China experiences only a minor appreciation in exchange rates, because China, compared to its trading partners like U.S. and Japan, is less dependent on imported oil. In addition, China's government usually imposes severe regulations on energy. Several important conclusions 
have been derived from this study. For instance, when oil price increases, there is an appreciation in the price of tradable goods relative to the price of non-tradable goods. Consequently, China can increase the price of tradable goods relative to non-tradable goods by a smaller proportion compared to its trading partners like U.S. and Europe. Amano \& Norden (1998) illustrated a theoretical interpretation of the link between these two variables. They concluded that appreciation in oil price leads to decrease in value of non-tradable goods (i.e., labor).

On the other hand, Chen \& Chen (2007) used monthly panel data of G7 countries and different measures of oil prices (Dubai, Brent and WTI) to demonstrate that oil prices is the dominant source of real exchange rate movements. They concluded that real oil prices can predict exchange rates, especially in the long-run. Cifarelli \& Paladino (2010) introduced a non-linear model for oil and four other commodity futures prices. They examined the dynamic behavior of futures returns on them, and detected an inverse relationship.

Using a structural vector autoregression (SVAR) and monthly data on global oil production, oil prices, global real economic activity, exchange rate, emerging market stock prices, and interest rates, Basher et al. (2012) studied different ways of capturing the unexpected rises in crude oil, and found that a positive shock in oil prices leads to a decline in both the emergy economies' stock markets and the US dollar exchange rate (against EURO). They also found that both rising in real economic activity and emerging stock market prices led to higher prices of oil. They concluded that higher economic activities and higher prices for emerging stock markets indirectly lean towards depressing the US dollar exchange rates.

In crude oil market, there are different ways to capture and interpret shocks (i.e., unexpected price changes). But how can we identify a price shock? In Hamilton's (2003) definition, a net oil price surge is considered as an oil price shock "which is the log change in the 
nominal price of oil relative to its previous three years high if positive, or zero otherwise". Based on a recursive structure, Kilian, Rebucci, \& Spatafora (2009) identifies that the supply shock, the real price of oil, and the global demand for oil, as three major shocks in the oil market. They found that the effects of oil demand shocks more powerful than the effects of oil supply shocks.

Evidence of appreciation in USD in case of a rise in oil price has been found by Clostermann \& Schnatz (2000) through detecting the relationship between USD and EURO. Bénassy-Quéré, Mignon, \& Penot (2007) applied cointegration and causality tests on monthly data of oil prices and US real exchange rate against EURO. They discussed the responses of oil prices to the emerging economies in Asia. They noted that a $10 \%$ increase in the oil price, in the long run, would result in the value of US dollars to increase by $4.3 \%$. In addition, they found that causality does not run from US dollars to oil price. As a result, USD fluctuations (even as the dominant oil price currency) do not have significant effects on oil prices.

On the contrary, the rise of China as an important player in both foreign exchange rate and oil market would change the relationship between oil prices and exchange rates, in particular, the causality would run from US dollar to the oil price. The reason behind this inversion is that due to the fixed peg of the Chinese yuan against US dollars, a depreciation in dollar leads to an appreciation of Chinese economic activity, and an increase in demand for oil, which would result in an appreciation in oil price. China's and India's increased share in the oil market had affected the role of the US in the oil market and has turned oil as an exogenous and threatening factor for the US economy (Lizardo \& Mollick, 2010). Along with that, Bénassy-Quéré, Mignon, \& Penot (2007) found that oil price is more volatile than US dollar.

Supporting the negative relationship between US dollar exchange rates and oil prices, Lizardo \& Mollick (2010) utilized monthly data for USD exchange rate, oil prices, the US money 
supply, and the US industrial production. They found that in the long-run, when the oil price goes up, the USD goes down against net exporter currencies like Russia, Canada, and Mexico. In addition, the value of the USD goes up against net importer currencies like Japan. Furthermore, an increase in oil prices will lead to USD experiencing a decline against currencies of countries such as the U.K. that are not considered a net exporter or importer. However, in the short-run, when the oil price goes up, the USD goes down against both exporting and importing countries. The logic behind this negative relationship is that increase in oil price means that US will spend more dollars to buy oil. This in turn, results in an increase in supply of dollar. Due to basic rules of supply and demand, an increase in US dollar supply results in a depreciation in USD value.

Results of Lizardo \& Mollick (2010) indicate that an increase in oil price results in a decline in production function in the US. Zalduendo (2006), by expanding the vector error correction (VEC) to parallel market exchange rates, and Narayan, Narayan, \& Prasad (2008) by using exponential generalized auto-regression conditional heteroskedasticity (EGARCH), investigated the impact of oil on US dollar exchange rates against Venezuela and Fiji, respectively. Both studies found that oil price is a significant determinant of the exchange rates.

Turning to the second category, a handful of studies highlight the impact of US dollar exchange rates on the fluctuations of oil prices. In general, most researchers, despite using different datasets, have found consistent results; that is, a long-term cointegrating relationship can be detected between real oil prices and real exchange rates and Granger causality only runs from the former to the latter.

Zhang, Fan, Tsai, \& Wei (2008) used vector auto-regression model and explored three spillover effects between exchange rates and oil prices. They found a substantial equilibrium cointegrating relationship between both USD exchange rate and oil markets. The authors also 
found that US dollar has an important effect on the international crude oil market, only in the long term.

Zhang, Fan, Tsai, \& Wei (2008) also studied the effects of a strong US dollar on oil prices and concluded that in the short run, a robust US dollar makes exporting-countries richer but in the long-run leads to a decline in demand for crude oil and fewer benefits for oil-exporting countries. Sadorsky (2000) investigated the interaction between various US dollar exchange rates and energy prices, and found a long-run equilibrium relationship between them. In addition, his results indicated Granger causality running from exchange rates to energy futures prices. Indjehagopian, Lantz, \& Simon (2000), used conventional unit root tests, weak exogeneity test, and a VEC model, and identified that movements in US dollar exchange rates against France and Germany currencies have a noticeable effect on movements in oil prices.

Looking for the dependence structure between US dollar exchange rates and oil prices in the copula-based model for (WTI) crude oil and US dollar index (USDX), Wu, Chung, \& Chang (2012) identified that as USD decreased substantially, an increase in oil price has been seen. They explained that three possible explanations could shed light on the negative relationship between USD and oil price: first, oil-exporting countries peg their currencies to the US dollar in order to make their purchasing power steady and avoid any harm. Second, a decrease in US dollar, will result in a decline in oil price for consumers in non-US dollar sections, and this decline will consequently cause an increase in demand for oil which leads to higher prices of oil. Third, when the value of USD declines, the returns on US dollar assets declines, and oil becomes more attractive for investment as a substitute commodity for foreign investors. This will result in in increase in the price of oil. 
Furthermore, Wu, Chung, \& Chang (2012) presented evidence of non-linearity in the relationship between oil price and USD. Based on this non-linearity, crude oil experienced a weaker negative association with US dollar in case of an increase in US dollar. On the other hand, crude oil experienced stronger negative interdependence with US dollar in case of a decrease in US dollar. They also observed that there is a difference in independence structure between oil price and US dollar exchange rates before and after 2003. Yousefi \& Wirjanto (2004), analyzed five OPEC countries to investigate the rggrvy of USD on the establishment of OPEC. They reported that there exists a negative association between oil price and USD such that a decrease in domestic currencies against USD leads to an appreciation in oil price. This is a practical policy for keeping export revenue stable. Looking for OPEC's member responses to the variations of US dollar, they concluded that OPEC countries earn more money by a strong dollar in the short-run but in the long-run, a strong dollar leads to a lower demand (a negative demand shock) for crude oil and less profit for them.

Beckmann \& Czudaj (2013) considered nonlinear adjustment dynamics and a distinction between nominal and real linkage as two previously neglected issues. They employed Markovswitching vector error correlation model, and by discriminating long-run and time-varying shortrun dynamics, found a causal relationship running from nominal exchange rates to nominal oil prices. It is worth mentioning that there is a similar pattern regarding the influence of nominal and real exchange rate on oil prices. A depreciation in USD exchange rate against oil-exporter countries and emerging markets with higher inflations, leads to an appreciation in oil prices (Beckmann \& Czudaj, 2013).

Blomberg \& Harris (1995) noted that in oil-exporting countries, an increase in domestic currency against the dollar, will result in an appreciation in the demand for oil which consequently 
leads to an appreciation in oil prices. Juan Carlos Reboredo, Rivera-castro, \& Zebende (2014), used daily observations of oil prices and US dollar exchange rates against six foreign currencies, and examined the negativity in the relationship between oil prices and exchange rates. They highlighted the significant impact of Great Recession on this relationship. Their study provides evidence that there is a negative and weak correlation between oil prices and exchange rates. In longer time periods, this negative correlation becomes weaker. However, after the onset of Great Recession, there is an increase in the strength of the negative correlation for all time periods. The authors concluded that the US dollar exchange rates, against both oil exporting and oil importing currencies, had a weak forecasting power for predicting oil price before the crises. However, this predictive power increased after the crises. In other word, Great Recession resulted in contagion and interdependence.

Krichene (2005) estimated a simultaneous equation model (SEM) which highlights the market power of oil producers by confirming the high-income elasticity and low price elasticity of demand for crude oil. This model provides evidence of an inverse effect of nominal effective exchange rate (NEER) on the price of crude oil in the short and long run.

In most empirical studies, various interpretations have been provided for the negative relationship between US dollar exchange rates and crude oil prices such that when the value of USD decreases, there is a decline in oil prices for non-US consumers which results in an increase in their demand for oil, and consequently an increase in oil prices. Another explanation indicates that a weaker USD means a reduction in USD denominated financial assets and makes oil more appealing as an investment.

As mentioned earlier in the introduction, evidence of bidirectional causality, unidirectional causality from either oil prices or US dollar exchange rates, and even no causality (i.e. 
independency of oil prices ad US dollar exchange rates from each other) have been provided for the relationship between oil prices and US dollar exchange rates. The evidence for unidirectional causality from oil prices to the exchange rates has been provided by (Amano \& Norden, 1998; Basher et al., 2012; Bénassy-Quéré et al., 2007; Coudert et al., 2007; Tiwari \& Albulescu, 2016). On the other hand, Beckmann \& Czudaj (2013) found unidirectional causality running from Exchange rates to the oil prices. Moreover, evidence of bidirectional causality have been found by (Chaudhuri \& Daniel, 1998; Prasad Bal \& Narayan Rath, 2015; Reboredo et al., 2014). Finally, researchers such as Habib et al. (2016), Reboredo (2012), and Zhang et al. (2008) found nocausality between oil prices and exchange rates based on different methods and time periods.

The oil dependence level of different countries could significantly influence the relationship between oil prices and US dollar exchange rates. Researchers provide evidence of a negative relationship between oil prices and US dollar exchange rates against net oil-exporting countries such as Canada, Saudi Arabia, and Mexico. However, we observe the opposite (i.e., a positive relationship) in net oil-importing countries such as Japan and South Korea (Lizardo \& Mollick, 2010).

Evidence of a positive relationship between oil prices and exchange rates have been provided by (Amano \& Norden, 1998; Basher, Haug, \& Sadorsky, 2012; Bénassy-Quéré, Mignon, \& Penot, 2007; and Chen \& Chen, 2007) while the negative relationship has been detected by (Akram, 2009; Narayan, Narayan, \& Prasad, 2008; Wu, Chung, \& Chang, 2012; and Zhang, Fan, Tsai, \& Wei, 2008). We see different results based on the difference in time periods used in the studies. Most papers have used monthly data (Amano \& Norden, 1998; Basher, Haug, \& Sadorsky, 2016; and Bénassy-Quéré, Mignon, \& Penot, 2007). However. Daily data has also been utilized 
(Narayan, Narayan, \& Prasad, 2008; Reboredo, Rivera-castro, \& Zebende, 2014; and Zhang, Fan, Tsai, \& Wei, 2008).

The conflicting results found in the literature could also be the result of different methodologies used by researchers. To capture the movements in the relationship between oil prices and exchange rates, different methods such as VAR, ECM, GARCH, and wavelet have been conducted. VAR, as one of the most common models to capture the causality in short-run, has been conducted by Alquist, Kilian, \& Vigfusson (2011); Lizardo \& Mollick (2010); and Prasad Bal \& Narayan Rath (2015). As mentioned earlier, the results of causality include all types of causalities (i.e., unidirectional, bidirectional and no causality). In cointegrated relationships, VECM is conducted by researchers such as Akram,(2004), Beckmann \& Czudaj (2013) and Chaudhuri \& Daniel (1998) to capture the long-run effects. Bénassy-Quéré, Mignon, \& Penot (2007) used both VAR and VECM and identified that there is a positive causality running form oil price to USD which will be strengthened in short-run due to emergence of China but this relationship reverses in long-run.

Although the linear causality between oil prices and exchange rates helps us capture some important characteristics of the relationship, the actual relation may not be linear. The possibility of a non-linear relationship between oil prices and exchange rates has been examined by researchers such as Akram (2004), Prasad Bal \& Narayan Rath (2015), and Tiwari \& Albulescu (2016) to shed more light on the actual interdependency. For instance, Akram (2004) found a dynamic inverse relationship between oil prices and the Norwegian exchange rates in which the relationship became much stronger when the price of oil decreased (falling less than 14 dollars per barrel). 
Another trend in the literature worth considering is the nominal and real measurements that have been used in different studies. Based on the purpose of each paper, researchers have utilized either nominal or real prices. The nominal US dollar exchange rate is simply calculated as domestic currency per one US dollar while the real US dollar exchange rate includes price index for both US and foreign currencies. Therefore, an increase in real US dollar exchange rates means an appreciation in purchasing power of US goods. Researchers such as Beckmann \& Czudaj (2013), Lizardo \& Mollick (2010) and Zhang, Fan, Tsai, \& Wei (2008) have used nominal exchange rates and oil prices while researchers such as Akram (2004), Chaudhuri \& Daniel (1998), and Tiwari \& Albulescu (2016) have used real prices in order to capture the real fluctuations of the US dollar and oil prices. 


\section{CHAPTER 4. METHODOLOGY}

In the context of time series regressions, as stated by Stock \& Watson (2007), the historical relationship can be a reliable forecast for the future based on the assumption that history tends to repeat itself. The concept of stationarity formulized this forecasting characteristic of time series variables. Based on Gujarati (2011), a time series sequence is said to be stationarity if it has a longitudinal constant mean and variance and the covariance value of two periods is solely reliant on the lag period considered, and is independent of the covariances' actual time. Mathematically, these three factors can be written as:

- Mean: $E\left(X_{t}\right)=\mu($ constant $\forall t)$;

- Variance: $\operatorname{Var}\left(X_{t}\right)=E\left(X_{t}-\mu\right)^{2}=\sigma^{2}($ constant $\forall t)$; and

- Covariance: $\operatorname{Cov}\left(X_{t}, X_{t+p}\right)=E\left[\left(X_{t}-\mu\right)\left(X_{t+p}-\mu\right)\right](\forall \operatorname{lags}=p)$.

Mean reversion (reverting back to the mean) and variance reversion (reverting back to the variations) are two important features of stationary time series. According to Gujarati (2011), if a time series is not stationarity (i.e., its mean and variance is not constant over time), attributing its variations to other time series is not possible and there is no use of these series for the purpose of forecasting. Furthermore, regression analysis between two non-stationary time series will lead to spurious regressions, with very high R-square (e.g., .99) and very high t-ratios whereas these two set of variables are not causally related to each other; in other words, the results found in the regression analysis have no economic meanings. Granger \& Newbold (2001) provide statistical evidence that an R-square almost equal to 1 would be a definite indicator of a spurious regression. Attribute trends, tenacious long-run fluctuations of a variable across time, and the instability in the population distribution are the main reasons for non-stationarity in time series data. In the event 
of a deterministic trend, which is nonrandom and fluctuating over time, the process of de-trending means regressing the variables on the time trend and taking the residuals. If the de-trended series is non-stationary, then the original variable is said to be trend nonstationary. On the other hand, if a variable follows a stochastic trend, then this sequence is a random function of time. Nelson \& Plosser (1982) noted that many US macroeconomic time series have stochastic trends. Random walk without drift (i.e., no intercept) is the simplest and most commonly used model of a stochastic trend, which is defined as in equation (1):

$$
X_{t}=X_{t-1}+u_{t}
$$

where $u_{t}$ is a white noise error term (with zero mean and fixed variance) and $X_{t}$ and $X_{t-1}$ is the value in time $t$ and time $t-1$ for the time series $X$, respectively.

The conventional approach to test for stationarity is to use the Augmented Dickey-Fuller test (ADF). This test was first proposed by Dickey \& Fuller (1981) to test for unit roots based on the assumption of a random walk. The test procedure contains regressing the time series sequence on its lag and test the unity of the autoregressive coefficient, as in equation (2):

$$
\begin{aligned}
& X_{t}=\rho X_{t-1}+u_{t,} \\
& \mathrm{H}_{0}: \rho=1 \text {; non-stationarity or unit root } \\
& \mathrm{H}_{0}: \rho<1 \text {; stationarity }
\end{aligned}
$$

Finding statistically significant results for Dickey-Fuller test indicates that the sequence is non-stationary and follows a random walk. 
To eliminate autocorrelation, Dickey \& Fuller (1981) improved their previous test by including extra lagged terms of the dependent variables in the equation, namely the Augmented Dicky-Fuller (ADF) test, as in equation (3).

$$
\begin{aligned}
& \Delta X_{t}=\alpha+\delta X_{t-1}+\sum_{i=1}^{i=n} \beta_{i} \Delta X_{t-1}+u_{t}, \\
& \mathrm{H}_{0}: \delta=0 ; X_{t} \text { is non-stationary } \\
& \mathrm{H}_{1}: \delta<0 ; X_{t} \text { is stationary. }
\end{aligned}
$$

Various statistical methods (i.e., criteria) exist for determining the lag length to be included in the ADF test, such as the Akaike Information Criterion (AIC) and the Schwarz Bayesian/Information Criterion (SBC, SIC). According to Stock \& Watson (2007), the number of lags should be chosen based on the balance between the marginal benefits of adding more lags and the marginal costs of additional error in estimation. For the current study, I consider including 16 lags to check whether the ADF test results are sensitive to the autoregressive terms included in the model. ADF test can be performed both with or without constant and linear trend. In this study, I consider ADF test both with and without a linear trend.

It needs to be stressed here that in this study I consider the logarithm of the oil prices and USD exchange rates. Time series data are often non-normally distributed; therefore, converting to their logarithms can reduce skewness and kurtosis. Additionally, the first difference of a logarithmic variable has a ready interpretation as returns. For instance, oil price returns and exchange rate returns can be defined as:

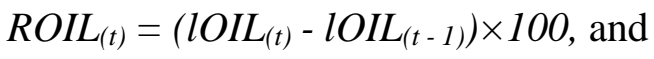

$$
\begin{aligned}
& \operatorname{REXCH}_{(t)}=\left(l E X C H_{(t)}-l E X C H_{(t-1)}\right) \times 100,
\end{aligned}
$$


where: $R O I L_{(t)}$ is oil price returns at time $t, l O I L_{(t)}$ is the logarithmic price of oil at time $t, l O I L_{(t-}$ 1) is the logarithmic price of oil at time $t-1, R E X C H_{(t)}$ is US dollar exchange rate returns, $l E X C H_{(t)}$ is the US dollar exchange rate in the logarithmic format at time $t$, and $l E X C H_{(t-1)}$ is the US dollar exchange rate in the logarithmic format at time $t-1$.

If two series are both non-stationary, then it is possible that these two series are cointegrated, i.e. their linear combinations are stationary. Granger (1981) introduced the concept of cointegration but this concept was worked out and described in great details by Engle \& Granger (1987) and later by Johansen (1995). As mentioned before, regressing non-stationary time series against another non-stationary variable leads to spurious regression with high and meaningless Rsquared. Taking differences until reaching stationarity and regressing one stationary time series against another is an effective way to solve this problem. However, Granger \& Newbold (2001) show that de-trending (e.g. taking first differences) may not eliminate the problem of spurious regressions if the two variables are cointegrated. In order to get a meaningful relationship, we need to instead find a stationary linear combination of the two-time series (e.g., $X_{t}$ and $Y_{t}$ ) which move together over time, as in equation (6):

$$
Y_{t}=\beta_{0}+\beta_{1} X_{t}+u_{t} .
$$

And taking the residuals:

$$
u_{t}=Y_{t}-\beta_{0}-\beta_{1} X_{t},
$$

if the residuals (linear combination of $X_{t}$ and $Y_{t}$ ) is stationary, then these two-time series are cointegrated. The above formula can be modified for the case when $X_{t}$ and $Y_{t}$ follow a time trend:

$$
Y_{t}=\beta_{0}+\beta_{1} X_{t}+\beta_{2}(\text { TIME })+u_{t}
$$


And taking the residuals:

$$
u_{t}=Y_{t}-\beta_{0}-\beta_{1} X_{t}-\beta_{2}(T I M E)
$$

More commonly, the test of cointegration have often taken the form of Johansen maximum likelihood test which is able to test for more than one cointegrating relationships when there are more than two variables. In general, there are a maximum of $n-1$ cointegration vectors for $n$ nonstationary variables. The null hypothesis of the Johansen maximum likelihood test is no cointegration against a set of sequential alternative hypotheses ranging from at most 1 to at most $(n-1)$ cointegrating relationships.

Based on the results from stationarity and cointegration tests, vector error correction (VEC) and vector auto-regression (VAR) models will be applied to cointegrated and noncointegrated time series, respectively. If the two series are not cointegrated, i.e., either at least one sequence is stationary or there does not exists a steady long-run relation between two nonstationary variables, then VAR model will be used. As Mahmoud (1984) and McNees (1986) stated, compared to the far more complex models, VAR is a simple model with more reliable forecasting power. The estimated coefficients from the VAR model can be used for Granger causality test.

On the other hand, if exchange rates and oil prices are cointegrated, our purpose of the analysis is then to estimate both the short- and long-run relationships between the two series. In general vector error autoregressive model (VAEM) "is constructed from the first differences of cointegrated variables, their lags, and some error correction terms" (Magee, 2013, p. 18). We can write a vector error correction model (VECM) as:

$$
D x_{t}=\mu+\Pi x_{t-1}+\sum_{i=1}^{p} \Gamma_{i} \mathrm{D} x_{t-i}+\mathrm{w}_{t}
$$


where $D x_{t}=x_{t}-x_{t-1,} x_{t}$ is an $m x l$ vector of variables, $\mu$ is the mean of time series and an $m x l$ vector of intercepts, $\Pi$ is considered as the coefficients matrices for each lag and $\Gamma_{\mathrm{i}}$ are the matrices for different lags.

Under the context of this research, consider for example, the equation for testing the causality running from oil prices to US dollar exchange rates. In a simple autoregressive distributed lag model (ARDL) with one lag, the regression equation may be written as:

$$
Y_{t}=\alpha_{0}+\alpha_{1} Y_{t-1}+\beta_{0} X_{t}+\beta_{1} X_{t-1}+u_{t},
$$

where $Y$ and $X$ are US dollar exchange rates and oil prices, respectively. The short-run or static effects of a change in $X_{t}$ is calculated by taking the partial derivative of $Y_{t}$ with respect to $X_{t}$ :

$$
\delta Y_{t} / \partial X_{t}=\beta_{0},
$$

where $u_{t}$ is iid $\left(0, \sigma^{2}\right)$. Therefore, the short-run response of $Y_{t}$ to a change in $\mathrm{X}_{\mathrm{t}}$ is represented by $\beta_{0}$. Since the logarithmic forms of the two variables are used in this study, the aforementioned partial derivative is considered as the elasticity between the two time series (i.e., we have a log-log model). Nevertheless, when time series are in equilibrium, the long-run or dynamic response of $Y_{t}$ to a change in $X_{t}$ (i.e., a permanent shock in $X_{t}$ ) is captured by:

$$
\delta Y_{t} / \partial X_{t}=\left(\beta_{0}+\beta_{1}\right) /\left(1-\alpha_{0}\right) .
$$

Equations (11) and (13) imply that an Error Correction Model (ECM) that incorporates the longrun relationship between oil prices and exchange rates can be written as:

$$
\begin{gathered}
R O I L_{t}=\delta^{o i l}\left(a+b l O I L_{t-1}+c l E X C H_{t-1}\right)+\sum_{i=2}^{i=n} \alpha_{i}{ }^{o i l} R O I L_{t-i}+\sum_{i=2}^{i=n} \beta_{i}^{o i l} R E X C H_{t-i}+u_{t,} \\
R E X C H_{t}=\delta^{e x c h}\left(a+b l E X C H_{t-1}+c l O I L_{t-1}\right)+\sum_{i=2}^{i=n} \alpha_{i}^{e x c h} R O I L_{t-i}+\sum_{i=2}^{i=n} \alpha_{i}{ }^{e x c h} R E X C H_{t-i}+u_{t} .
\end{gathered}
$$


Or:

$$
\begin{gathered}
\operatorname{ROIL}_{t}=\delta^{o i l}(E C T)_{t-1}+\sum_{i=2}^{i=n} \alpha_{i}{ }^{o i l} R O I L_{t-i}+\sum_{i=2}^{i=n} \beta_{i}{ }^{o i l} R E X C H_{t-i}+u_{t,} \\
R E X C H_{t}=\delta^{\text {exch }}(E C T)_{t-1}+\sum_{i=2}^{i=n} \beta_{i}{ }^{\text {exch }} R O I L_{t-i}+\sum_{i=2}^{i=n} \alpha_{i}{ }^{e x c h} R E X C H_{t-i}+u_{t},
\end{gathered}
$$

where $b=1, c=\left(\beta_{0}+\beta_{1}\right) /\left(1-\alpha_{0}\right)$, and $\delta=\left(1-\alpha_{1}\right)$.

In equations (16) and (17), the error correction term (ECT) is incorporated in the regression model along with the short-run relationships. The above equations are known as the Error Correction Model (ECM), which has enjoyed considerable popularity in empirical applications since it resolves stochastic trends from the nonstationary time series, converting the spurious regression into a valid ordinary least square regression (Asteriou \& Hall, 2007).

In the context of the present analysis, both short-run and long-run effects between oil prices and exchange rates are considered. For instance, in equation (16), short-run effects are represented by the coefficient of REXCH (the differenced term), and long-run effects are denoted by ECT. The coefficient of the ECT, $\delta$ is called error correction coefficient (i.e., adjustment coefficient), representing the speed of adjustment in case of a deviation from the long-run equilibrium (i.e., in case of disequilibrium). When two time series are not in equilibrium (e.g., as a result of a shock to either variable or both at time $t-1$ ), ECT deviates from zero (e.g., becomes greater or smaller than zero). In the event of positive deviations, the value of $\delta$ will be negative to cancel out the effects of those positive shocks. Consequently, $\delta$ denotes the speed of adjustment towards the equilibrium when deviations occur. For instance, $\delta=1$ implies a very fast adjustment in which about $100 \%$ of a deviation from the equilibrium point is corrected within each time period while $\delta=0$ means nothing is corrected within that period. The adjustment coefficient $\delta$ ensures that any deviations 
from the equilibrium point will be corrected and the two series do not deviate further away from the long-run relationship.

Finally, in order to measure the dependency between USD dollar exchange rates and crude oil prices, I conduct Granger causality test based on the estimation results of VAR and ECM. In econometric literature, according to Granger (1969), causality happens when the history of one variable can help to predict (i.e., granger cause) another variable. More explicitly, Thanh Binh (2013) states that "a variable $Y_{t}$ is said to Granger-cause $X_{t}$, if $X_{t}$ can be predicted with greater accuracy by using past values of the $Y_{t}$ variable rather than not using such past values, all other terms remaining unchanged" (p. 89). Here, under the context of our analysis, Granger causality test is essentially to determine whether the history of one of our variables - oil prices or US dollar exchange rates - has predictive value on the current value of the other variable.

In the case of VAR model with first difference (when the two series are non-stationary and not cointegrated), the Granger causality test can be specified as:

$$
\begin{aligned}
& \operatorname{ROIL}_{(t)}=\alpha_{0}+\sum_{i=1}^{i=n} \alpha_{i}{ }^{\text {oil }} \operatorname{ROIL}_{(t-i)}+\sum_{i=1}^{i=n} \beta_{i}{ }^{\text {oil }} \operatorname{REXCH}_{(t-i)}+u_{o i l(t)}, \\
& \operatorname{REXCH}_{(t)}=\alpha_{0}+\sum_{i=1}^{i=n} \alpha^{e^{\text {exch }}}{ }_{i} \operatorname{REXCH}_{(t-i)}+\sum_{i=1}^{i=n} \beta_{i}{ }^{\text {exch }} \operatorname{ROIL}_{(t-i)}+u_{\text {exch }(t)}, \\
& \mathrm{H}_{0}: \beta_{1}=\beta_{2}=\cdots=\beta_{n}=0 ; \text { no Granger causality } \\
& \mathrm{H}_{1} \text { : at least one of the } \beta s \text { is not equal to zero; Granger causality }
\end{aligned}
$$

In equation (18), $R O I L_{(t)}$ is affected by its historical (or lagged) values and lagged values of $\operatorname{REXCH}_{(t)}$, and simultaneously, the value of $R E X C H_{(t)}$ is affected by its historical (or lagged) values and lagged values of $R_{E X C H}$ (t), as in equation (19). According to Gujarati (2011), $u_{\text {oil }(t)}$ and $u_{\text {exch }(t)}$ are assumed to be uncorrelated white noise error term. Wooldridge (2003) stated that from 
the point of view of forecasting and projecting, the contemporaneous values of independent variables (i.e., $\mathrm{REXCH}_{(t)}$ in equation 19) are not usually included in the calculation. According to Asteriou \& Hall (2007), past history is a valuable heritage in time series analysis and the most common matter is to evoke as much information as possible from this valuable background, especially in the context of time series forecasting.

Granger causlaity tests specified in equations (18) and (19) may lead to four different scenarios. In the first scenario, coefficients of the lagged returns of US dollar exchange rates in equation (18), $\beta s$ are jointly statistically significant but coefficients of the lagged returns of oil prices in equation (19), $\beta s$, are not jointly statistically significant, implying that US dollar exchange rates Granger cause oil prices, or equivalently, future prices of oil can be predicted by the past values of US dollar exchange rates with more accuracy. In the second scenario, coefficients of the lagged returns of US dollar exchange rates in equation (18), $\beta s$, are not jointly statistically significant but coefficients of the lagged returns of oil prices in equation (19), $\beta s$, are jointly statistically significant, implying that oil prices Granger cause US dollar exchange rates and that future prices of US dollar exchange rates can be predicted more accurately by including the past values of oil prices. However, exchange rates do not Granger cause oil prices. In these two scenarios, we have unidirectional Granger causality running from one variable to the other.

In the third scenario, we reject both joint hypotheses, implying that both variables Granger cause the other and that the historical values of one variable are useful to predict the future values of the other. In this scenario there exists a bi-directional Granger causality between the two series. In the last scenario, neither of the two null hypotheses can be rejected, so there is no evidence of Granger causality from either direction, thus the two time series are considered independent from each other. 
For the error correction model when the two variables are cointegrated, similar null hypotheses can be constructed. Specifically, for ECM models in equations (16), the null and alternative hypotheses are:

$\mathrm{H}_{0}: \beta_{1}=\beta_{2}=\cdots=\beta_{n}=0 ;$ no Granger causality

$\mathrm{H}_{1}$ : at least one of the $\beta^{\prime} s$ is not equal to zero; Granger causality 


\section{CHAPTER 5. DATA}

In order to investigate the dependency between crude oil prices and exchange rates, I collected daily (five working days per week), weekly and monthly time series data, from January $3^{\text {rd }}, 2000$ to September $1^{\text {st }}, 2017$, for crude oil prices and US dollar exchange rates against a variety of foregin currencies, including Australian dollar (AUD/USD), Canadian dollar (CAD/USD), Euro (EUR/USD), Japanese yen (JPY/USD), Mexico peso (MXN/USD), Norway Krone (NOK/USD), and the United Kingdom pound sterling (UK/USD). Daily and monthly exchange rates, as well as oil prices were obtained from Federal Reserve Bank of Saint Louis, ${ }^{2}$ while weekly data were computed as the arithmetic average of the daily data each week. In total, I obtained 4441, 933, and 213 daily, weekly, and monthly observations for each time series, respectively. Due to the small sample of quarterly and annual data, they were not considered in the present study.

In order to choose the set of countries to be included in the analysis, some principles are used. First, I consider both net oil-exporting and net oil-importing countries. Second, they must all have active traded, market-based currencies. Finally, all countries should be substantial business partners of the United States. For example, Mexico exported close to $95 \%$ of its net oil to the US and the US imported more than $80 \%$ of its crude oil from Canada. ${ }^{3}$ Canada and Mexico are both big oil-producers in the world, while Japan, Australia, and the Euro Zone are all oil importers. According to the EIA, the UK was a net importer of oil prior to 1980 s, but with the opening of North Sea production, it became a net exporter. However, since 2005 it has been a net importer of oil. Norway is a big oil-exporter, and most of its oil exports go to other countries in Europe. In addition, because of the market power of OPEC to manipulate prices of oil by manipulating the

\footnotetext{
${ }^{2}$ See https://www.stlouisfed.org/.

3 see https://www.eia.gov/todayinenergy/detail.php?id=16971.
} 
supply section, and the political issues between the US and Russia (e.g., imposing sanctions against Russia and etc.), these two major oil suppliers are not included in this study (Yousefi \& Wirjanto, 2004). The diversity of countries included in the analysis allows me to evaluate whether the relationship between oil prices and exchange rates varies by the countries dependence of oil imports, as well as their trading activities with the U.S.

Since the fundamental objective of the present research is to examine the relationship between US dollar exchange rates and oil prices from the viewpoint of market trading activities, nominal data on exchange rates and oil prices are satisfactory for the analyses. Additionally, since all variables are nonstationary in logarithmic form and stationary at first differences (as shown in the next section), essentially returns are used in the model. As a result, using nominal prices and exchange rates should pose little concern to my analysis.

The crude oil price (in US dollars per barrel) used in the study refers to the price of West Texas Intermediate (WTI) oil, also known as the light sweet oil. The WTI oil prices, serving as the benchmark oil prices in the United States, are closely related to other crude oil benchmarks such as Dubai, Maya, and Brent (Reboredo, 2011).

Figures 1-3 plot the daily, weekly, and monthly US dollar exchange rates, along with the WTI oil prices from 2000 to 2017 , respectively. The US dollar exchange rates are defined as the value of foreign currencies to one US dollar, and thus a rise in the exchange rate implies that the US dollar has appreciated while the foreign currency has depreciated. On the other hand, when the exchange rate drops, the US dollar has depreciated while the foreign currency has become more valuable. Some major fluctuations in both oil prices and US dollar exchange rates can be easily detected in the figures. For instance, Figure 3 suggests that in 2001-2002, 2002-2003, and 2015-2016 the US dollars experienced three positive jumps against most of the foreign currencies, 
except for the currencies in Mexico and the United Kingdom. From 2000 to 2002, the oil price rose sharply, the value of other currencies (mostly oil-importing countries) meanwhile declined. However, for Mexico, which exported close to $95 \%$ of its net oil to the US during that period, its exchange rate against the US dollar did not depreciate. Additionally, it can be seen that oil had experienced a positive slope till the historical point of 146 USD per barrel in 2008, followed by several subsequent fluctuations.

The descriptive statistics and distributional characteristics of all raw, log and returns data are presented in Tables 1, 2, and 3, respectively. By taking first differences in the logarithm of two sequential observations, the returns on US dollar exchange rates against different foreign currencies and crude oil prices were computed in daily, weekly and monthly periods. In the tables, the standard deviations of the raw variables indicate how spread apart is the distribution of each variable. The coefficient of variations indicates that among the raw exchange rates, MXN/USD and AUD/USD had the highest volatility while GBP/USD was the most stable exchange rate during the sample period. Consistent with the findings of Wu, Chung, \& Chang (2012) that commodity prices are less stable than exchange rates, I find oil prices had a higher coefficient of variations than most of the US dollar exchange rates.

At a glance, we can see that the skewness statistics, indicating the degree of asymmetry, of almost all variables are positive and significant, suggesting that oil prices and foreign exchange rates are significantly skewed to the right. The only exception is the Japanese Yen which is significantly skewed to the left. For all variables, the median is less than mean which is consistent with positive kurtosis, except for Japan where the mean is less than median and has a negative kurtosis. With respect to the distribution at the tails, only in Mexico peso is the kurtosis larger than three, suggesting that the MPS/USD has larger, thicker tails compared to the normal distribution. 
In the logrimatic form, the skewness is significantly positive for all variables except for oil prices, JPY/USD, and UK/USD that are negatively skewed. All variables have significant and positive kurtosis except Mexico whose excess kurtosis is no longer significant. Notably, the skewness and excess kurtosis for logarithmic variables are smaller than the values in the orginal level data. For returns, the excess skewness coefficient was no longer significant in EUR/USD and JPY/USD anymore, though it remains positively significant for all other series.

Correlation coefficients between variables are shown in Tables 4, 5 and 6. As expected, most of currencies have a significant positive correlation with another currency. However, MXP/USD is an exception-it is negatively correlated with AUD/USD, CAD/USD, and EUR/USD but positively correlated with NOK/USD, UK/USD, and the oil. Unlike most of the countries considered in the analysis, Norway and Mexico is a pure oil exporting country, and Great Britain is much less dependent on imported oils than other industrial countries.

Among all currencies, the Canadian dollar has the highest negative correlation with oil prices, with a correlation coefficient of -.90 . All the correlation coefficients are significant except for the correlation between JPY/USD and the UK/USD. In the log form, the story of correlations remained the same as in the raw variables. Nevertheless, there are more changes when we move to the returns form. For instance, the correlation between Japanese yen and oil prices turned to signficiantly positive. Perhaps more interestingly, the correlation between Mexico and oil prices became significantly negative.

In general, we observe a statistically significant negative correlation between oil prices and US dollar exchange rates against most of the foreign currencies considered in the analysis at daily and weekly frequencies. With the exception of Japanese Yen, the magnitude of the correlation coefficient becomes even stronger when we move to the monthly period, as shown in Table 7 . 
Why is Japan so different? Constrained by domestic resources, Japan is a pure oil importing country, whose currency will become weaker relative to US dollars when the oil price rises. Although this positive dependency between oil prices and JPY/USD is significant in daily and weekly time periods, at the monthly frequency the two series are not statistically significantly correlated. One possible explanation is that at the longer horizon, Japan may have higher flexibility in substituting oil with other energy resources, thereby reducing the negative effect bring about by US dollar exchange rate fluctuations and delink Japanese Yen from oil price changes. It may also be possible that at the longer horizon, both Japanese Yen and oil prices are subject to other less correlated confounding factors, decreasing the linkage between Yen and oil prices.

Finally, we observe in the correlation coefficient tables that CAD/USD and NOK/USD are the two exchange rates most negatively correlated with oil prices. Since Canada and Norway are both pure oil-exporting countries, oil price rises would move wealth from oil importing countries to the oil exporting countries. Therefore, when oil price rises, the currencies for Canada and Norway become more valuable than US dollars. 


\section{CHAPTER 6. EMPIRICAL RESULTS}

As mentioned in the methodology part, I converted all exchange rates and oil prices to their logarithms to reduce the skewness and kurtosis. After that, I applied ADF test on daily, weekly, and monthly data both with and without trend to detect the stationarity of the variables. For robustness, I used various lags (1-6) in the ADF test. Our null and alternative hypotheses are:

$$
\begin{aligned}
& \mathrm{H}_{0} \text { : time series sample is non-stationary } \\
& \mathrm{H}_{1} \text { : time series sample is stationary }
\end{aligned}
$$

Table 8 shows the ADF test results for the daily data when 1, 2, 4, and 6 lags are used. Testing results for 3 and 5 lags are qualitatively similar, and hence are not presented. As can be seen, the null hypothesis of non-stationarity (unit root) was not rejected on all logarithmic data. However, the null hypothesis of non-stationarity was rejected for all returns (first difference of the log variables), suggesting that both exchange rates and oil prices are first-difference stationary. Table 8 also indicates that including or excluding a trend in the ADF test does not alter our unit

root test results. All logarithmic variables (i.e., with and without trend) are non-stationary, and all return variables (i.e., with and without trend) were are stationary. As can be seen in Tables 9 and 10 , the stories for weekly and monthly variables are the same as the daily data.

For two nonstationary variables, it is possible that they revert to some long-run relationships. Therefore, in the second step I conducted Johansen maximum likelihood test to determine the existence of a cointegrating relationship between the two variables. To conduct the Johansen test, we must first determine the number of lags to be included in the model. In general, we need to avoid both too few (i.e., less than optimal lags) and too many autoregressive terms (i.e., more than optimal lags). Otherwise, potentially valuable information will be omitted, or more 
coefficients than we need will be estimated, both leading to inaccurate estimates in our analysis. To do so, I used the AIC criterion to select the optimal number of lags used in the Johansen maximum likelihood test (Johansen, 1995).

Johansen test results for daily data are presented in Table 11. As can be seen in the table, the JPY/USD, MXN/USD, and the UK/USD are not cointegrated with oil prices. Hence, there does not exist a long-run (i.e., equilibrium) relationship between those exchange rates and oil prices. However, the US dollar exchange rates against Australian dollars, Canadian dollars, Euro, and Norway krone are cointegrated. Therefore, we will need to account for these long-run relationships (i.e., equilibrium) between those exchange rates and oil prices in the model in the next step.

Table 12 shows the results of Johansen test for the weekly data. The countries whose currencies are not cointegrated with oil prices remain the same as the daily data. Nevertheless, the number of lags designated by AIC has changed. The results for monthly data, are presented in Table 13. In monthly time series, the story of the long-run relationship between US dollar exchange rates and oil prices are a bit different. The US dollar exchange rates against the currencies of Japan, Mexico, the United Kingdom, and Norway do not have any cointegrating or long-run relationship with oil prices. On the other hand, US dollar exchange rates against the Australian dollars, Canadian dollars, and Euro do cointegrate with oil prices, indicating the existence of a long-run relationship.

In the next step, I estimated vector autoregressive models (VAR) for non-cointegrated variables and vector error correction models (VECM) for cointegrated variables to check for both short-run and long-run relationships between US dollar exchange rates and oil prices. Results from these two models are then used for Granger causality test to determine the lead-lag relationship between exchange rates and oil prices. 
Starting with Granger causality tests between non-cointegrated variables, VAR models are conducted and different results for different time series were captured. Table 14 illustrates the relationship of daily JPY/USD, MXN/USD, and UK/USD with oil prices. Testing results suggest that almost none of the daily relationships are significant. JPY/USD exchange rates and oil prices do not Granger cause each other- they are hence considered as independent time series. In other words, the past values of JPY/USD exchange rates are not useful to predict oil prices and vice versa. The same story occurs between MXN/USD and oil prices, as well as UK/USD and oil prices. Although the test statistics of UK/USD and oil prices is statistically significant at 10\%, we consider it as non-significant since the p-value is very close to 0.1 .

In weekly time series, the story remains the same as the daily data. As Table 15 suggests, all weekly exchange rates are independent from oil prices and none of them has a predicative power to oil prices. Same as the daily data, the effects of lagged UK/USD exchange rates on oil prices are only significant at $10 \%$.

For monthly data, some major changes can be detected. Table 16 illustrates the Granger causality test results for JPY/USD, MXN/USD, NOK/USD, and UK/USD exchange rates with oil prices at the monthly frequency. The F-values suggest that MXN/USD and NOK/USD exchange rates Granger cause oil prices but JPY/USD and UK/USD exchange rates do not Granger cause oil prices. Therefore, only the past currencies of MXP and NOK can help predicting the future values of oil prices. On the other hand, oil prices only Granger cause UK/USD exchange rates. For the monthly variables, past values of oil prices are only useful when predicting US dollar exchange rates against the British Pound.

For exchange rates that are cointegrated with oil prices, I estimated VECM models to detect the causality between two variables. Table 17 shows the Granger causality test results and the 
adjustment coefficients of the error correction term for daily AUD/USD, CAD/USD, EUR/USD and oil prices. There exists Granger causality running from oil prices to the Australian dollar but not vice versa. Significant adjustment coefficient for the error correction term in the oil prices equation indicates that when deviations from the long-run relationship occurs, oil prices adjust back to equilibrium with AUD/USD.

For the short-run relationship between CAD/USD and oil prices, it can be seen that there exists a bi-directional Granger causality in which the historical values of one sequence are useful to predict the future values of the other variable. Moreover, the adjustment coefficient is significant in the oil price equation, indicating that when deviations to the long-run relationship (i.e., equilibrium) occurs, oil prices adjust back to the equilibrium while CAD/USD does not adjust.

For the short-run relationship between EUR/USD and oil prices, it can be seen that there does not exist any Granger causality from either direction; they are considered independent in the shortrun. The significant adjustment coefficient in the oil price equation indicates that when the long-run (i.e., equilibrium) relationship does not hold, oil prices adjust back to equilibrium in the short-run.

For NOK/USD and oil prices, it can be seen that there exists a bi-directional Granger causality in the short-run in which the historical values of one series are useful to predict the future values of the other variable.

Table 18 includes the Granger causality and adjustment coefficients for weekly AUD/USD, CAD/USD, EUR/USD and NOK/USD exchange rates and oil prices. For the short-run relationship between AUD/USD and oil prices, it can be seen that there does not exist any Granger causality between the two variables, suggesting that the past values of neither sequence contain predicative power of the other. The significant adjustment coefficient in the oil price equation indicates that when 
deviations to the long-run (i.e., equilibrium) relationship occur, oil prices adjust back to the equilibrium.

For CAD/USD and oil prices at the weekly frequency, it can be seen that there exists a unidirectional Granger causality running from oil prices to CAD/USD exchange rates. It appears that only the historical values of oil prices are useful to predict the future values of the CAD/USD exchange rates. Moreover, the adjustment coefficient is significant in the oil prices equation, suggesting that oil price adjusts back to the long-run equilibrium when deviations occur.

Additionally, EUR/USD and oil prices are independent from each other at the weekly frequency, as the Granger causality test fail to reject the null hypothesis in either the oil price or EUR/USD equation. However, the adjustment coefficient is significant in the oil price equation, suggesting that oil prices adjust back to the cointegrating relationship when a deviation occurs. Similar results are found for NOK/USD and oil prices at the weekly frequency: there does not exist any Granger causality between the two series and they are considered independent in the short-run. Moreover, the adjustment coefficient is significant in the oil price but not in the NOK/USD equation. So, in case of deviations from the long-run relationship, oil prices adjust back to the equilibrium, while NOK/USD exchange rates do not make adjustment.

Finally, Table 19 reports the Granger causality test results and the adjustment coefficient for monthly AUD/USD, CAD/USD, and EUR/USD exchange rates and oil prices. It can be seen that there does not exist any Granger causality between AUD/USD and oil prices, and the past values of neither sequence helps to forecast the other variable. A significant adjustment coefficient is found in the oil price equation but not in the AUD/USD equation, indicating that oil prices adjust back to equilibrium when a deviation occurs, while AUD/USD exchange rates do not adjust. 
For the short-run relationship between monthly CAD/USD and oil prices, it can be seen that there exists a unidirectional Granger causality running from the CAD/USD exchange rate to oil prices. Therefore, only the historical values of CAD/USD exchange rates can help to predict the future values of the oil prices values. Moreover, the adjustment coefficient is significant in the oil price equation but not when the CAD/USD is the dependent variable. For the relationship between EUR/USD and oil prices, it can be seen from Table 19 that there does not exist any Granger causality and that they are considered independent in the short-run. However, oil prices does adjust back to equilibrium when deviations from the long-run relationship occur.

Finally, Table 20 summarizes the results from all time periods for both cointegrated and noncointegrated cases. As discussed earlier, in daily and weekly time periods, all non-cointegrated variables are independent (i.e., no causality running between oil prices and the exchange rate) while at the monthly frequency, the results are more complexed-there exists unidirectional causality running from oil prices to the exchange rates, unidirectional causality from exchange rates to oil prices, and even no causality.

Table 20 suggests that we have even more diverse results for cointegrated data in different time periods. For the daily data, unidirectional causality running from oil prices to the exchange rates, and bidirectional causality are seen in the results. However, in the monthly data, no-causality and unidirectional causality running from exchange rates to the oil prices were detected. It can be seen that in the weekly data, all exchange rates are independent from oil prices in the short-run. 


\section{CHAPTER 7. DISCUSSIONS}

These results suggest that the relationship between oil prices and USD exchange rates is perhaps more complexed than commonly considered. Indeed, their relationship appears to vary by the data frequency used, the country considered, and the horizon (long- vs. short-run) investigated. For long-run relationships, AUD/USD, CAD/USD, and EUR/USD are cointegrated with the oil price at all data frequencies, while NOK/USD is cointegrated with oil prices at both the daily and weekly frequencies. By contrast, JPY/USD, MXN/USD, and UK/USD are not cointegrated with oil prices at any of the frequencies, suggesting that their relationships are determined predominately by short-run supply and demand fluctuations. Additionally, NOK/USD is not cointegrated with oil prices at the monthly frequency.

When the long-run relationship breaks up, we can see that in all cases, oil prices adjust back to equilibrium when a deviation occurs and US dollar exchange rates lead the adjustment (see Table 17). $\delta$ (i.e., the error correction coefficient) in all cases are negative and significant only when oil prices are used as the dependent variable. In case of equilibrium, the amount of error correction term (ECT) is equal to zero, and there is no deviation from an optimal point between oil prices and US dollar exchange rates. However, in case of disequilibrium, the ECT is the amount, either positive or negative, that the linear combination between oil prices and exchange rates, deviates from the optimal point and is not equal to zero.

The adjustment coefficient indicates the percentage of adjustment when deviations to the long-run equilibrium occur. For instance, the negative value of $\delta(=-.02)$, indicates that oil prices will adjust $2 \%$ of the correction (i.e., adjustment) in each time period when deviations occur. The adjustment coefficients have smaller magnitudes in both daily and weekly frequencies compared to the monthly data. For instance, Table 19 suggests that at the monthly frequency, oil prices will 
correct $25 \%, 27 \%$, and $85 \%$ of the deviations in the EUR/USD, AUD/USD, and CAD/USD equations, respectively. At the weekly frequency, the percentage of corrections is between $5 \%$ and $14 \%$ per week, while at the daily frequency, it ranges from $1 \%$ to $4 \%$.

The magnitude of the adjustment coefficient is the largest in the CAD/USD equation at all frequencies, perhaps due to the large oil exports from Canada to the US and the active economic activities between the two countries. For instance, the US imported about $40 \%$ of its oil from Canada in 2017, even more than the amount imported from all OPEC countries which totaled to about $34 \% 5$. The results indicate that it is worthwhile to invest in oil importing infrastructures from Canada compared to other oil-exporters such as Mexico and Norway.

Based on the VAR and VECM results, I investigate the direction of causality between exchange rates and oil prices. It should be noted that the causality used in the present study is defined as whether the past values of one variable help to predict the future value of another variable. In other words, this "causality" does not indicate a true causal relationship between the two variables. Rather, it simply indicates from the time series forecasting perspective, whether one variable has predicative power on the other variable.

As it was illustrated in Tables 14 and 15, the causality was absent for non-cointegrated time series, including JPY/USD and oil, MXN/USD and oil, and UK/USD and oil at both daily and weekly time periods. However, Table 16 suggests that this conclusion does not hold when the monthly data is used. In particular, there exists a causality running from MXN/USD to oil prices, running from NOK/USD to the price of oil and finally running from oil prices to the UK/USD exchange rates. The results should not come as a surprise since we observe an increasing dependency between exchange rates and oil prices in monthly frequency relative to weekly and daily data, as evidenced by Table 7 . The rise in the magnitude of the correlation coefficient can 
potentially explain the larger predictability power in monthly period compared to daily and weekly data. Perhaps more intuitively, both oil prices and exchange rates are rather volatile on a daily or weekly basis due to market-specific or idiosyncratic shocks, so weekly or daily lagged values may not help predict values of the other variable.

The story for cointegrated time series is a bit different. Table 17 shows that oil prices have predictive power for all exchange rates except EUR/USD. By contrast, for non-cointegrated daily variables, we have more causal relationship running from exchange rates to oil prices (both CAD/USD and NOK/USD Granger cause the oil prices). Although the correlations between time series in daily and weekly time periods are the same, there are some noticeable changes when we move from daily to monthly frequency for cointegrated variables. Table 18 indicates that in monthly period, only one Granger causality relationship exists which runs from oil prices to CAD/USD exchange rates. Table 19 indicates an absence of causality except in the relationship between oil prices and CAD/USD — it appears that CAD Granger causes oil prices.

In summary, we can see that in case of unidirectional causality running from oil prices to the exchange rates, causality only occurs for the currencies of oil importing countries (i.e., causality runs from oil prices to US dollar exchange rates against Australia and the United Kingdom). On the other hand, in case of unidirectional causality running from exchange rates to the oil prices, causality only occurs for oil exporting countries (i.e., causality runs from Canadian Dollars and Mexican Peso to oil prices). This implies that policy makers can use past values of oil prices to forecast the future values of US dollar exchange rates against oil importers. However, in order to predict the future values of oil prices, the US dollar exchange rates against oil exporters (i.e., Canada, Norway, and Mexico) should be used instead of the exchange rates of oil importers. 
As discussed in the introduction and literature review sections, there exist a handful of studies that have looked at the relationship between oil price and exchange rates, some based on the importing or exporting status of a country. How do findings in the present research compare to previous studies? In general, results are complicated. For example, Jahan-parvar \& Mohammadi (2011) used real exchange rates and oil prices for fourteen oil-exporting countries, and found evidence of all types of causalities (i.e., unidirectional, bidirectional, and no causality) in the shortrun. Yang, Cai, \& Hamori (2017) employed the wavelet coherence framework and found significant effects of crude oil in determining the exchange rates of only oil-exporting countries, implying more sensitivity of oil-exporting countries' exchange rates to the shocks in oil prices compared to the oil-importing countries. Habib \& Kalamova (2007) investigated the impacts of real oil prices on three major oil-exporting countries exchange rates, and found unidirectional causality running from oil prices to Norway and Saudi Arabia exchange rates and no causality between oil prices and Russia exchange rates.

Results from this research confirm some findings from previous studies. For instance, these results differ between oil importing and oil exporting countries, and even for oil importing or oil exporting countries, results are not identical. However, these results also identify rather different pictures in the direction of causalities between exchange rates and oil prices compared to previous studies. The conflicting results found in the literature, as well as this study, suggests that more studies are needed to identify the sources of these disparities. 


\section{CHAPTER 8. CONCLUSIONS}

The purpose of this study is to determine the dependency between oil prices and US dollar exchange rates of a variety of countries at different time periods. Consistent with most studies that have found a negative (contemporaneous) relationship between US dollar exchange rates and oil prices (Akram, 2009; Wu, Chung, \& Chang, 2012; and Zhang, Fan, Tsai, \& Wei, 2008), this negative contemporaneous relationship has been detected in this study for daily, weekly, and monthly periods for US dollar exchange rates against all oil-importing and oil-exporting countries, as suggested by the correlation coefficients.

By using vector autoregressive model (VAR) and vector error correction model (VECM), the interdependency of oil prices with US dollar exchange rates against both oil-importing and oilexporting countries are analyzed to examine both the short- and long-run relationships between oil prices and USD exchange rates. Furthermore, using the Granger causality test, the predictability of variables and direction of causality were examined.

The main findings of this study can be summarized as follows: the dependency between oil prices and exchange rates differs by the countries considered and the frequency of data used. For non-cointegrated variables, in daily and weekly frequencies, US dollar exchange rates and oil prices behave independently from each other, hence, no evidence of causality exists between them. However, at the monthly frequency, some evidences of unidirectional causality have been detected running from MXN/USD and NOK/USD towards oil prices. Furthermore, for cointegrated variables, the number and diversity of causal relationships increased-oil prices Granger causes AUD/USD and also there is bidirectional Granger causality between both CAD and NOK with oil prices. 
However, the number of causal relationships in weekly and monthly data declined only to a unidirectional causality running from oil prices to CAD/USD exchange rates. It seems that oilexporting countries (i.e., the supply side of oil market) have more influence on fluctuations of oil prices than oil-importing countries (i.e., the demand part of the oil market). Canada and Norway both are considered as industrial and wealthy oil-exporting countries with powerful currencies which any changes in their currencies have a significant impact on fluctuations in oil prices in the short-run. Also, fluctuations in oil prices have higher effects in demand side of the oil market. Put it in another word, our results indicated that demand side of the oil market is more sensitive than the supply side which is consistent with the results of Amano \& Norden (1998).

For the long-run relationship, in all time periods, oil prices adjust back to deviations from the long-run equilibrium while exchange rates do not adjust. Additionally, the percentage of correction increases when we move from daily and weekly frequencies to the monthly data. The adjustment coefficient is the highest for the CAD/USD-oil relationship, perhaps due to the Canada's large oil exports to the U.S. and the active trading activates between the two countries.

There are a number of limitations to this study. For instance, only a few countries have been included in the study, further insights can be gained by including OPEC countries and Russia to the analysis. Furthermore, given the massive changes occurred to the oil and exchange rates market over the past two decades, the relationship between oil prices and US dollar exchange rates may not a constant. Future studies may wish to apply time varying models to an even longer sample period to estimate the differential effect of oil prices on exchange rates, as well the impact of exchange rates on oil prices during different sub-samples. In addition, Granger causality does not equal real causality and only shows the ability for predicting one variable based on past values of another variable. In addition, the sign of causality cannot be detected by this method. Further 
research can use other methods to examine the results, and investigate whether the findings vary as a function of the method used.

Finally, future studies need to be conducted to determine why the relationship between oil prices and US dollar exchange rates varies at different frequencies, and what determines the direction of causality. 


\section{REFERENCES}

Akram, Q. F. (2004). Oil Prices and Exchange Rates: Norwegian Evidence. Econometrics Journal, 7, 476-504. https://doi.org/10.1111/j.1368-423X.2004.00140.x

Akram, Q. F. (2009). Commodity prices, interest rates and the dollar. Energy Economics, 31(6), 838-851. https://doi.org/10.1016/j.eneco.2009.05.016

Alquist, R., Kilian, L., \& Vigfusson, R. J. (2011). Forecasting the price of oil. Handbook of Economic Forecasting (Vol. 2). https://doi.org/10.1016/B978-0-444-53683-9.00008-6

Amano, R. A., \& Norden, S. Van. (1998). Oil prices and the rise and fall of the US real exchange rate. Journal of International Money and Finance, 17, 299-316.

Arouri, M. E. H., \& Nguyen, D. K. (2010). Oil prices, stock markets and portfolio investment: Evidence from sector analysis in Europe over the last decade. Energy Policy, 38(8), 45284539. https://doi.org/10.1016/j.enpol.2010.04.007

Asteriou, D., \& Hall, S. G. (2007). Applied Econometrics: a Modern Approach using Eviews and Microfit. Palgrave Macmillan.

Backus, K. D., \& Crucini, M. J. (2000). Oil prices and the terms of trade. International Economics, 50(4), 185-213. https://doi.org/10.1111/1467-9396.00248

Basher, S. A., Haug, A. A., \& Sadorsky, P. (2012). Oil prices , exchange rates and emerging stock markets. Energy Economics, 34, 227-240. https://doi.org/10.1016/j.eneco.2011.10.005

Basher, S. A., Haug, A. A., \& Sadorsky, P. (2016). The impact of oil shocks on exchange rates: A Markov-switching approach. Energy Economics, 54, 11-23. 
https://doi.org/10.1016/j.eneco.2015.12.004

Beckmann, J., \& Czudaj, R. (2013). Oil prices and effective dollar exchange rates. International Review of Economics and Finance, 27, 621-636. https://doi.org/10.1016/j.iref.2012.12.002

Beckmann, J., Czudaj, R., \& Arora, V. (2017). The Relationship between Oil Prices and Exchange Rates: Theory and Evidence.

Bénassy-Quéré, A., Mignon, V., \& Penot, A. (2007). China and the relationship between the oil price and the dollar. Energy Policy, 35, 5795-5805. https://doi.org/10.1016/j.enpol.2007.05.035

Blomberg, S., \& Harris, E. (1995). The Commodity-Consumer Price Connection: Fact or Fable? Economic Policy Review, 1(3), 21-38. Retrieved from http://papers.ssrn.com/sol3/papers.cfm?abstract_id=1028825

Camarero, M., \& Tamarit, C. (2002). Oil prices and Spanish competitiveness. A cointegrated panel analysis. Journal of Policy Modeling, 24(6), 591-605. https://doi.org/10.1016/S01618938(02)00128-X

Campbell, J. Y., \& Clarida, R. H. (1987). The Dollar and Real Interest Rates. NBER Working Paper Series, (2151).

Carruth, A. A., Hooker, M. A., \& Oswald, A. J. (1998). Unemployment Equilibria and Input Prices : Theory and Evidence from the United States. The Review of Economics and Statistics, 80(4), 621-628.

Chaudhuri, K., \& Daniel, B. C. (1998). Long-run equilibrium real exchange rates and oil prices. Economics Letters, 58, 231-238. 
Chen, S., \& Chen, H. (2007). Oil prices and real exchange rates. Energy Economics, 29, 390404. https://doi.org/10.1016/j.eneco.2006.08.003

Cifarelli, G., \& Paladino, G. (2010). Oil price dynamics and speculation. A multivariate financial approach. Energy Economics, 32(2), 363-372. https://doi.org/10.1016/j.eneco.2009.08.014

Clarida, R., \& Gali, J. (1994). SOURCES OF REAL EXCHANGE RATE FLUCFIJATIONS: HOW IMPORTANT ARE NOMINAL SHOCKS? NBER Working Paper Series (Vol. 4658).

Clostermann, J., \& Schnatz, B. (2000). The determinants of the euro-dollar Exchange Rate. Synthetic Fundamentals and a Non-Existing Currency. Reproduction, (May). https://doi.org/10.2139/ssrn.229472

Coudert, V., Mignon, V., \& Penot, A. (2007). Oil price and the Dollar. Energy Studies Review, 15(2), 1-18.

Dauvin, M. (2014). Energy prices and the real exchange rate of commodity-exporting countries. International Economics, 137, 52-72. https://doi.org/10.1016/j.inteco.2013.11.001

Dickey, D. A. ., \& Fuller, W. A. . (1981). Likelihood Ratio Statistics for Autoregressive Time Series with a Unit Root. Econometric Society Stable, 49(4), 1057-1072.

Engle, R. F., \& Granger, C. W. J. (1987). Co-Integration and Error Correction: Representation, Estimation, and Testing. Econometrica, 55(2), 251. https://doi.org/10.2307/1913236

Fayyad, A., \& Daly, K. (2011). The impact of oil price shocks on stock market returns: Comparing GCC countries with the UK and USA. Emerging Markets Review, 12(1), 61-78. https://doi.org/10.1016/j.ememar.2010.12.001

Gisser, M., \& Goodwin, T. H. (1986). Crude Oil and the Macroeconomy: Tests of Some Popular 
Notions. Journal of Money, Credit and Banking, 18(1), 95-103.

Golub, S. S. (1983). Oil Prices and Exchange Rates. The Economic Journal, 93(371), 576-593.

Granger, C. W. J. (1969). Investigating Causal Relations by Econometric Models and Crossspectral Methods. The Econometric Society Stable, 37(3), 424-438.

Granger, C. W. J. (1981). Some properties of time series data and their use in econometric model specification. Journal of Econometrics, 16(1), 121-130. https://doi.org/10.1016/03044076(81)90079-8

Granger, C. W. J., \& Newbold, P. (2001). Spurious regression in econometrics. ECONOMETRIC SOCIETY MONOGRAPHS, 33, 109-118.

Gujarati, D. N. (2011). Econometrics by example. Palgrave Mcmillan.

Habib, M. M., Butzer, S., \& Stracca, L. (2016). Global Exchange Rate Configurations: Do Oil Shocks Matter. IMF Economic Review, 64(3), 443-470. https://doi.org/10.1057/s41308016-0001-5

Habib, M. M., \& Kalamova, M. M. (2007). ARE THERE OIL CURRENCIES? THE REAL EXCHANGE RATE OF OIL EXPORTING COUNTRIES.

Hamilton, J. D. (1983). Oil and the Macroeconomy since World War II. Journal of Political Economy, 91(2), 228-248. https://doi.org/10.1086/261140

Hamilton, J. D. (2003). What is an Oil Shock? NBER Working Paper Series, 3.

Hammoudeh, S., \& Aleisa, E. (2004). Dynamic relationships among GCC stock markets and NYMEX oil futures. Contemporary Economic Policy, 22(2), 250-269. https://doi.org/10.1093/cep/byh018 
Hammoudeh, S., Li, H., \& Jeon, B. (2003). Causality and volatility spillovers among petroleum prices of WTI, gasoline and heating oil in different locations. North American Journal of Economics and Finance, 14(1), 89-114. https://doi.org/10.1016/S1062-9408(02)00112-2

Huang, Y., \& Guo, F. (2007). The role of oil price shocks on China â€ ${ }^{\mathrm{TM}}$ s real exchange rate. China Economic Review, 18(July 2005), 403-416. https://doi.org/10.1016/j.chieco.2006.02.003

Indjehagopian, J. P., Lantz, F., \& Simon, V. (2000). Dynamics of heating oil market prices in Europe. Energy Economics, 22(2), 225-252. https://doi.org/10.1016/S0140-9883(99)000341

Jahan-parvar, M. R., \& Mohammadi, H. (2011). OIL PRICES AND REAL EXCHANGE RATES IN OIL-EXPORTING COUNTRIES: A BOUNDS TESTING APPROACH Mohammad. The Journal of Developing Areas, 45, 309-318. Retrieved from http://linkinghub.elsevier.com/retrieve/pii/S0928765597000274

Johansen, S. (1995). Likelihood-based inference in cointegrated vector autoregressive models. Oxford University Press on Demand.

Keane, M. P., \& Prasad, E. S. (1996). Employment and Wage Effects of Oil Price Changes:A Sectoral Analysis. The Review of Economics and Statistics.

Kilian, L., Rebucci, A., \& Spatafora, N. (2009). Oil shocks and external balances. Journal of International Economics, 77(2), 181-194. https://doi.org/10.1016/j.jinteco.2009.01.001

Krichene, N. (2005). A Simultaneous Equations Model for World Crude Oil and Natural Gas Markets. International Monetary Fund, 1-25. 
Krugman, P. R. (1983). Oil andthe dollar. In Bhandari, J.S., Putnam,B.H. (Eds.), Economic Inter- dependence and Flexible Exchange Rates. Cambridge University Press, Cambridge.

Lin, S. X., \& Tamvakis, M. (2001). Spillover effects in energy futures markets. Energy Economics, 23(1), 43-56. https://doi.org/10.1016/S0140-9883(00)00051-7

Lizardo, R. A., \& Mollick, A. V. (2010). Oil price fl uctuations and U . S . dollar exchange rates. Energy Economics, 32, 399-408. https://doi.org/10.1016/j.eneco.2009.10.005

M. Corden, W. (1984). Booming Sector and Dutch Disease Economics : Survey and Consolidation. Oxford Journals, 36(3), 359-380.

Magee, L. (2013). Unit Roots, Cointegration, VARs and VECMs. Retrieved from https://socialsciences.mcmaster.ca/magee/761_762/02-Time series models B-notes.pdf

Mahmoud, E. (1984). Accuracy in forecasting: A survey. Journal of Forecasting, 3(2), 139-159. https://doi.org/10.1002/for.3980030203

McNees, S. K. (1986). Forecasting Accuracy of Alternative Techniques: a Comparison of U.S. Macroeconomic Forecasts. Journal of Business \& Economic Statistics, 4(1), 5-15.

Meese, R., \& Rogoff, K. (1988). Was it Real? The Exchange Rate-Interest Differential Relation Over the Modern Floating- Rate Period. The Journal of Finance, 43(4), 933-948.

Narayan, P. K., Narayan, S., \& Prasad, A. (2008). Understanding the oil price-exchange rate nexus for the Fiji islands. Energy Economics, 30(5), 2686-2696. https://doi.org/10.1016/j.eneco.2008.03.003

Nelson, C. R., \& Plosser, C. R. (1982). Trends and random walks in macroeconmic time series. Some evidence and implications. Journal of Monetary Economics, 10(2), 139-162. 
https://doi.org/10.1016/0304-3932(82)90012-5

Park, J., \& Ratti, R. A. (2008). Oil price shocks and stock markets in the U.S. and 13 European countries. Energy Economics, 30(5), 2587-2608. https://doi.org/10.1016/j.eneco.2008.04.003

Perron, B. Y. P. (1989). The Great Crash, the Oil Price Shock, and the Unit Root Hypothesis. The Econometric Society, 57(6), 1361-1401.

Phelps, E. S. (1994). Structural slumps. Cambridge, MA: Harvard University Press.

Prasad Bal, D., \& Narayan Rath, B. (2015). Nonlinear causality between crude oil price and exchange rate: A comparative study of China and India. Energy Economics, 51, 149-156. https://doi.org/10.1016/j.eneco.2015.06.013

Reboredo, J. C. (2012). Modelling oil price and exchange rate co-movements. Journal of Policy Modeling, 34(3), 419-440. https://doi.org/10.1016/j.jpolmod.2011.10.005

Reboredo, J. C., Rivera-castro, M. A., \& Zebende, G. F. (2014). Oil and US dollar exchange rate dependence : A detrended cross-correlation approach. Energy Economics, 42, 132-139. https://doi.org/10.1016/j.eneco.2013.12.008

Sadorsky, P. (2000). The empirical relationship between energy futures prices and exchange rates. Energy Economics, 22, 253-266.

Sari, R., Hammoudeh, S., \& Soytas, U. (2010). Dynamics of oil price, precious metal prices , and exchange rate. Energy Economics, 32(2), 351-362. https://doi.org/10.1016/j.eneco.2009.08.010

Stock, J. H., \& Watson, M. W. (2007). Introduction to Econometrics. 
Thanh Binh, P. (2013). UNIT ROOT TESTS, COINTEGRATION, ECM, VECM, AND

CAUSALITY MODELS. Retrieved March 9, 2017, from

http://charitythinking.weebly.com/uploads/4/5/5/4/45542031/topics_in_time_series_econo metrics.pdf

Throop, A. W. (1993). A generalized uncovered interest parity model of exchange rates.

Economic Review, 2, 3-16. Retrieved from http://ideas.repec.org/a/fip/fedfer/y1993p316n2.html\%5Cnhttp://www.frbsf.org/publications/economics/review/1993/93-2_3-16.pdf

Tiwari, A. K., \& Albulescu, C. T. (2016). Oil price and exchange rate in India: Fresh evidence from continuous wavelet approach and asymmetric, multi-horizon Granger-causality tests. Applied Energy, 179, 272-283. https://doi.org/10.1016/j.apenergy.2016.06.139

Trehan, B. (1986). Oil Prices, Exchange Rates and the U.S. Economy: An Empirical Investigation. Economic Review, Federal Reserve Bank of San Francisco, 4, 25-43. https://doi.org/10.1017/CBO9781107415324.004

Wooldridge, J. M. (2003). Introductory econometrics: A modern approach. Nelson Education.

Wu, C., Chung, H., \& Chang, Y. (2012). The economic value of co-movement between oil price and exchange rate using copula-based GARCH models. Energy Economics, 34(1), 270-282. https://doi.org/10.1016/j.eneco.2011.07.007

Yang, L., Cai, X. J., \& Hamori, S. (2017). Does the crude oil price influence the exchange rates of oil-importing and oil-exporting countries differently? A wavelet coherence analysis. International Review of Economics and Finance, 49(May 2016), 536-547. https://doi.org/10.1016/j.iref.2017.03.015 
Yousefi, A., \& Wirjanto, T. S. (2004). The empirical role of the exchange rate on the crude-oil price formation. Energy Economics, 26(5), 783-799. https://doi.org/10.1016/j.eneco.2004.06.001

Zalduendo, J. (2006). Determinants of Venezuela’s Equilibrium Real Exchange Rate. IMF Working Paper, WP/06/74, 3-17.

Zhang, Y., Fan, Y., Tsai, H., \& Wei, Y. (2008). Spillover effect of US dollar exchange rate on oil prices. Journal of Policy Modeling, 30, 973-991. https://doi.org/10.1016/j.jpolmod.2008.02.002 


\section{FIGURES AND TABLES}

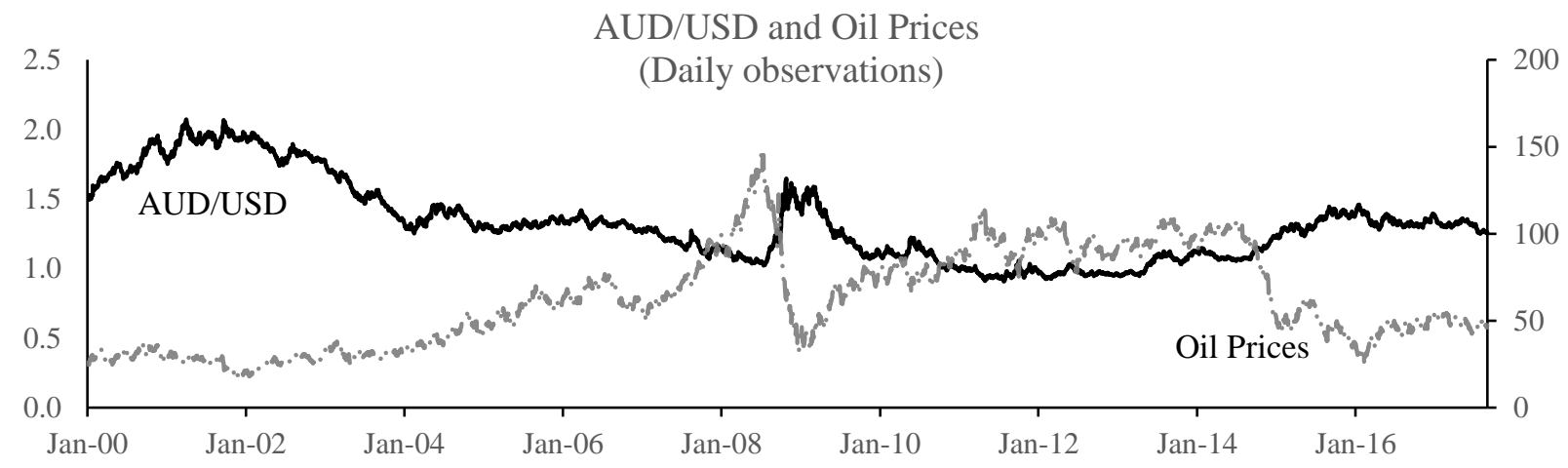

CAD/USD and Oil Prices

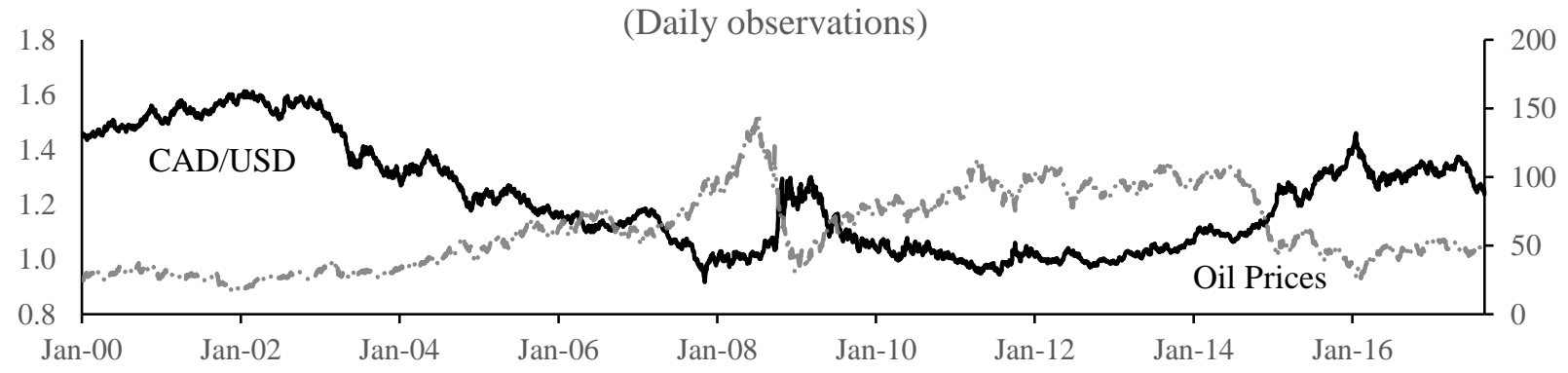

EUR/USD and Oil Prices

(Daily observations)

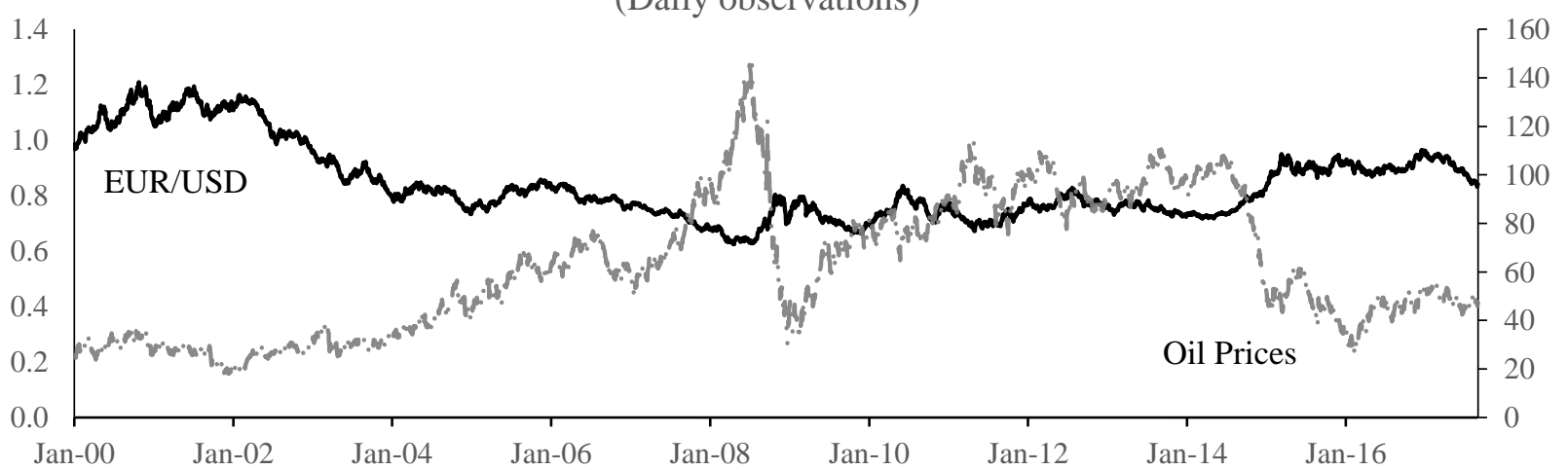

Figure 1: Daily Crude oil spot prices (WTI) and major US dollar exchange rates (1 ${ }^{\text {st }}$ January 2000 to $1^{\text {st }}$ September 2017) 
JPY/USD and Oil Prices
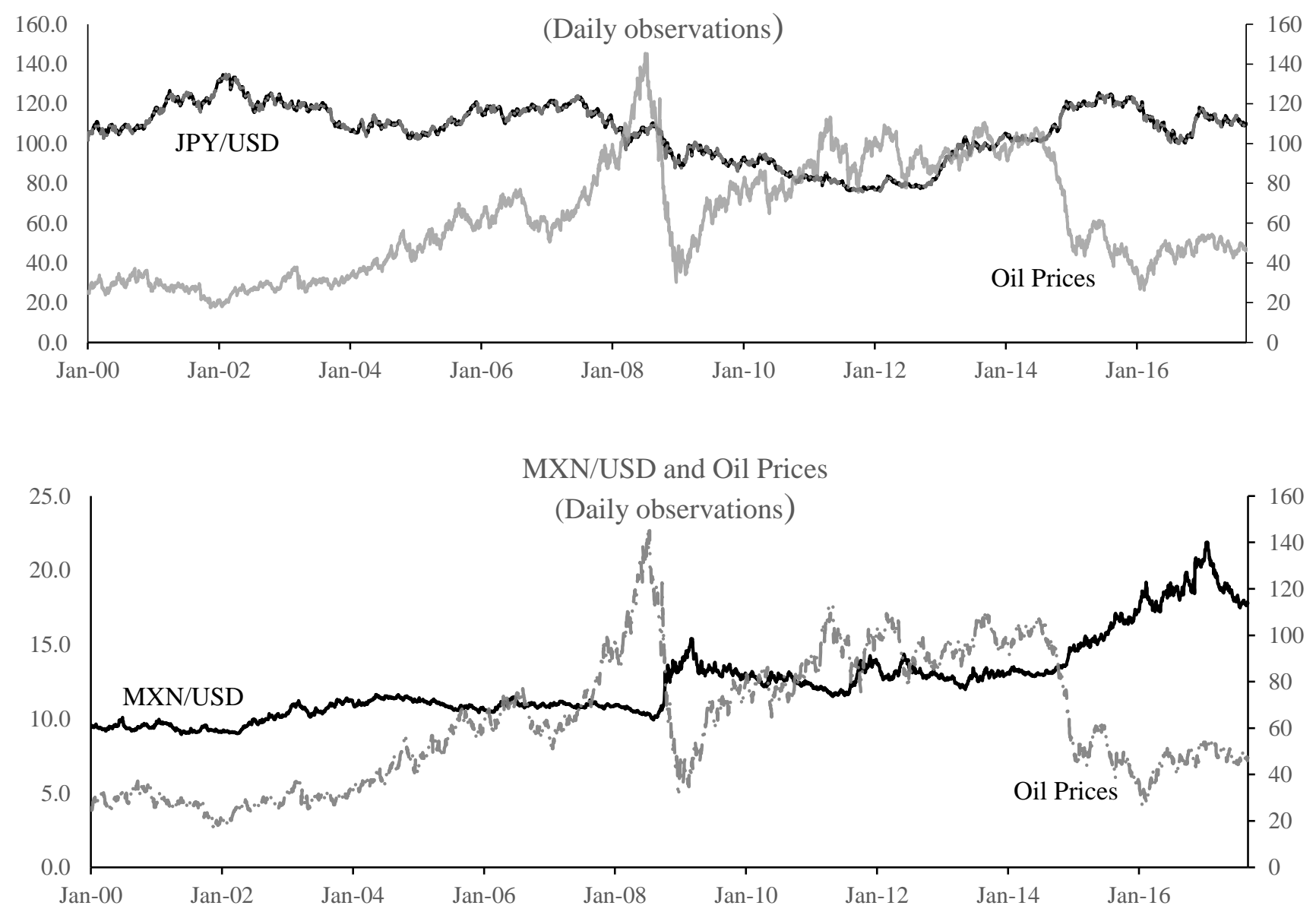

NOK/USD and Oil Prices

(Daily observations)

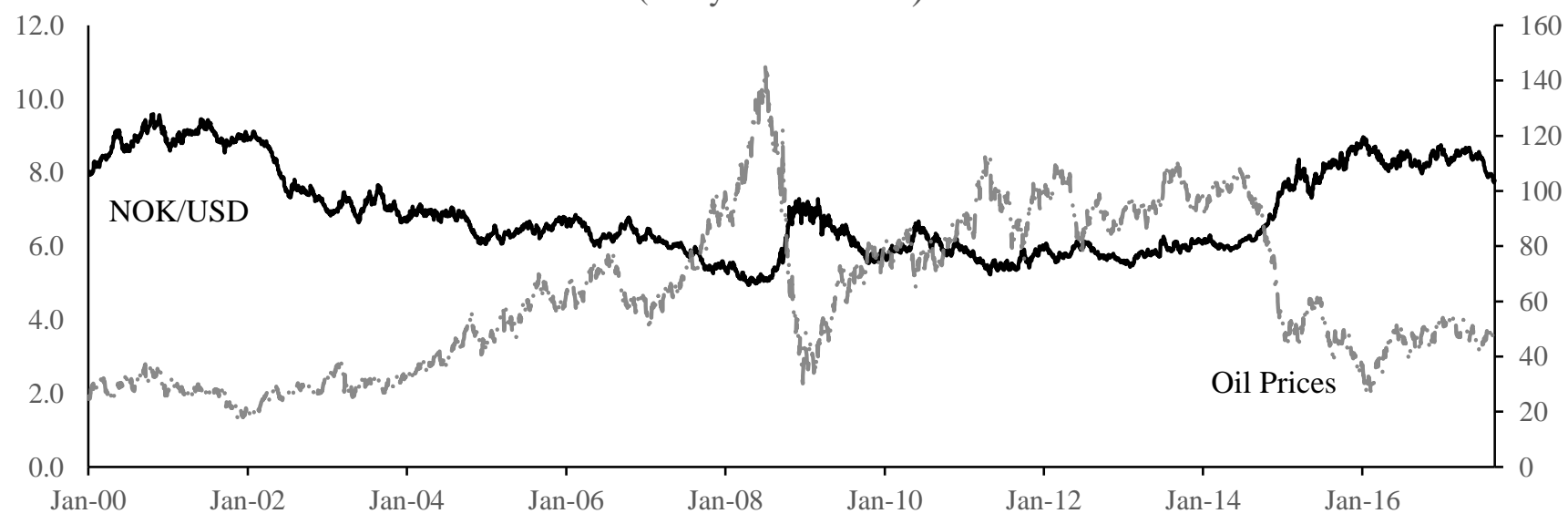

Figure 1: (continued). Daily Crude oil spot prices (WTI) and major US dollar exchange rates ( $1^{\text {st }}$ January 2000 to $1^{\text {st }}$ September 2017) 


\section{GBT/USD and Oil Prices}

(Daily observations)

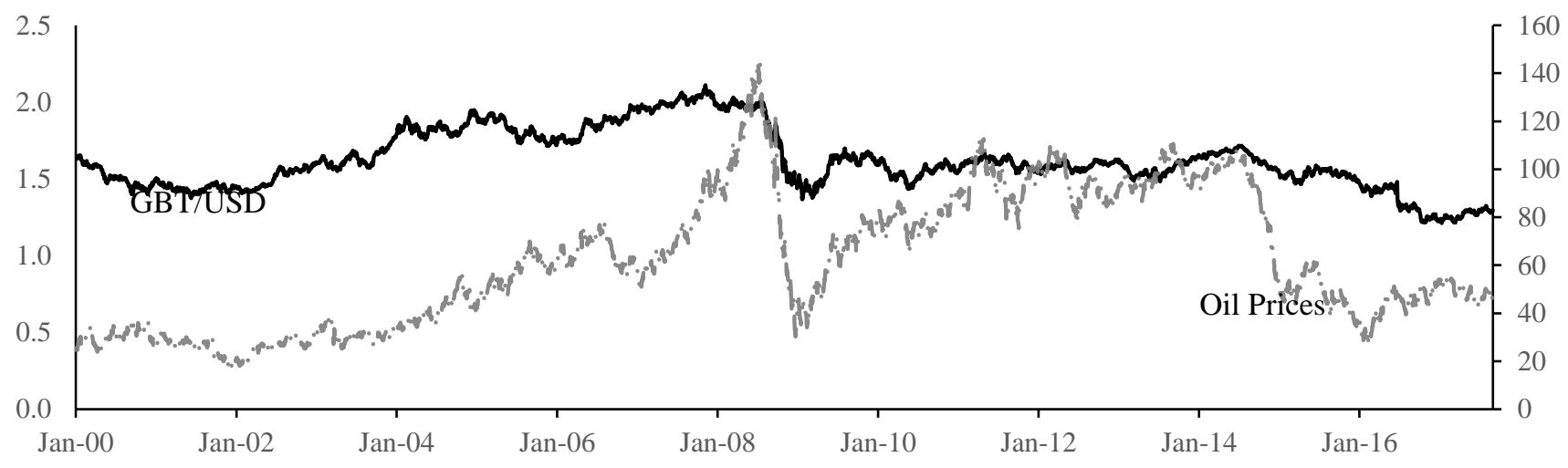

Figure 1: (continued). Daily Crude oil spot prices (WTI) and major US dollar exchange rates ( $1^{\text {st }}$ January 2000 to $1^{\text {st }}$ September 2017) 


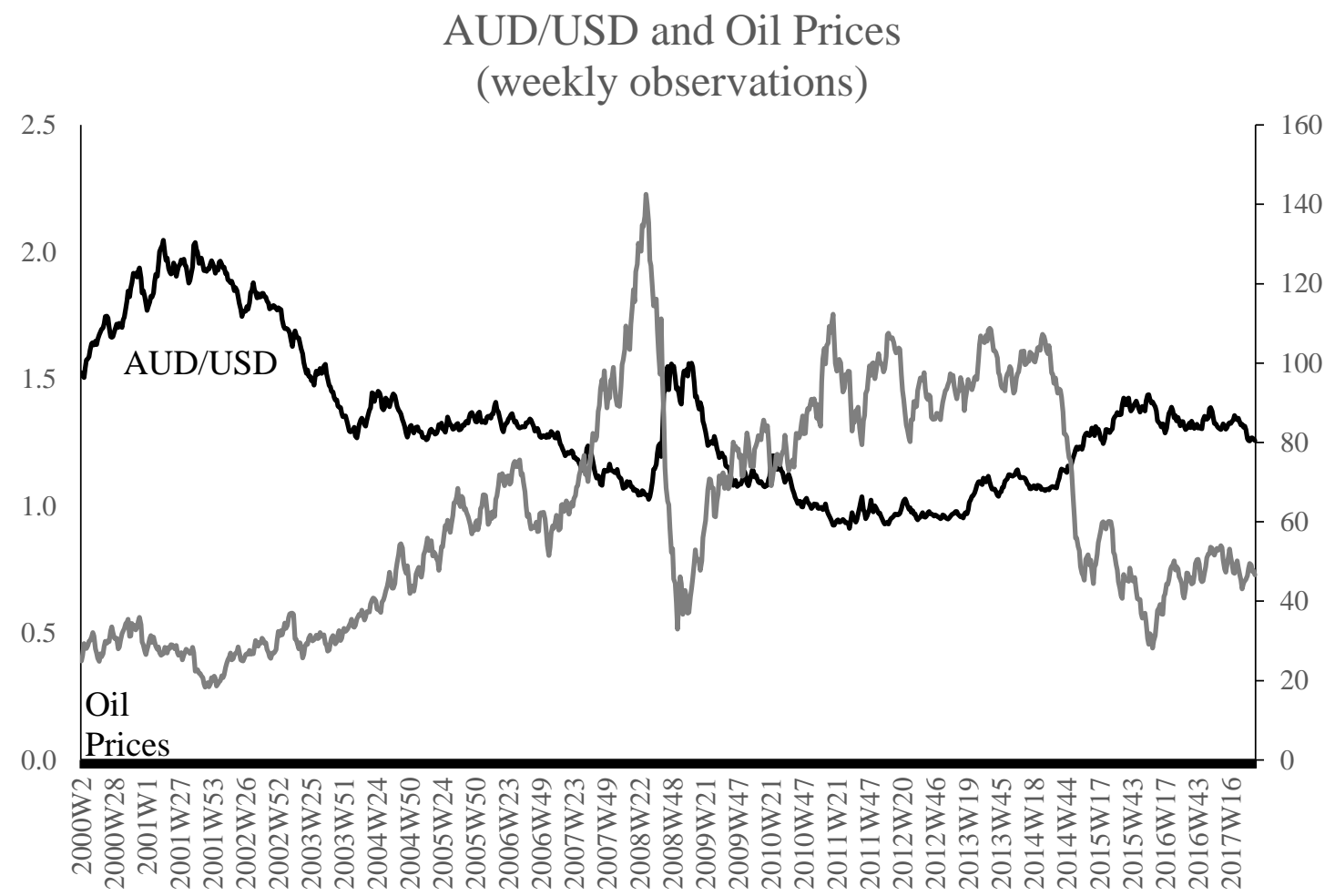

CAD/USD and Oil Prices

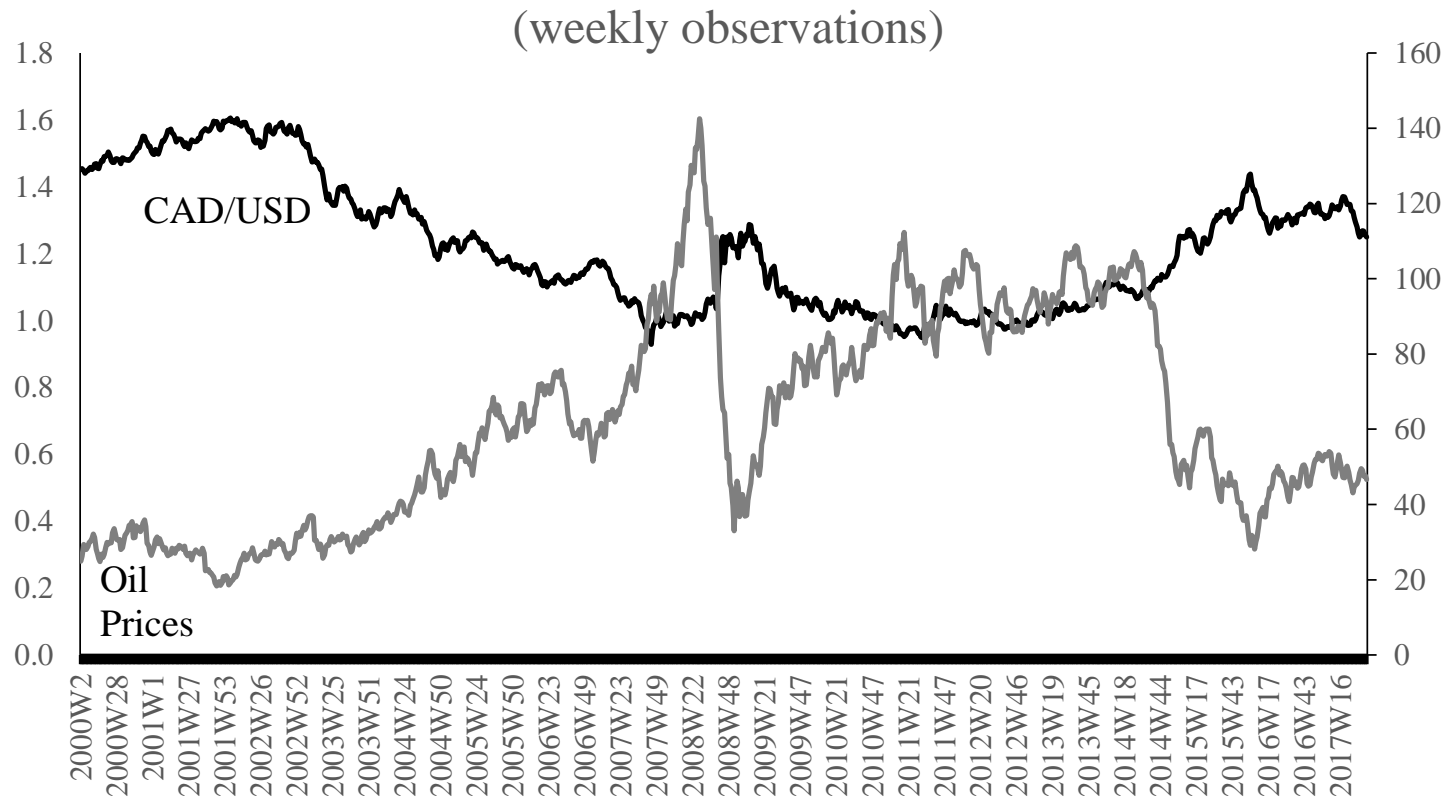

Figure 2: Weekly Crude oil spot prices (WTI) and major US dollar exchange rates (1 ${ }^{\text {st }}$ January 2000 to $1^{\text {st }}$ September 2017) 

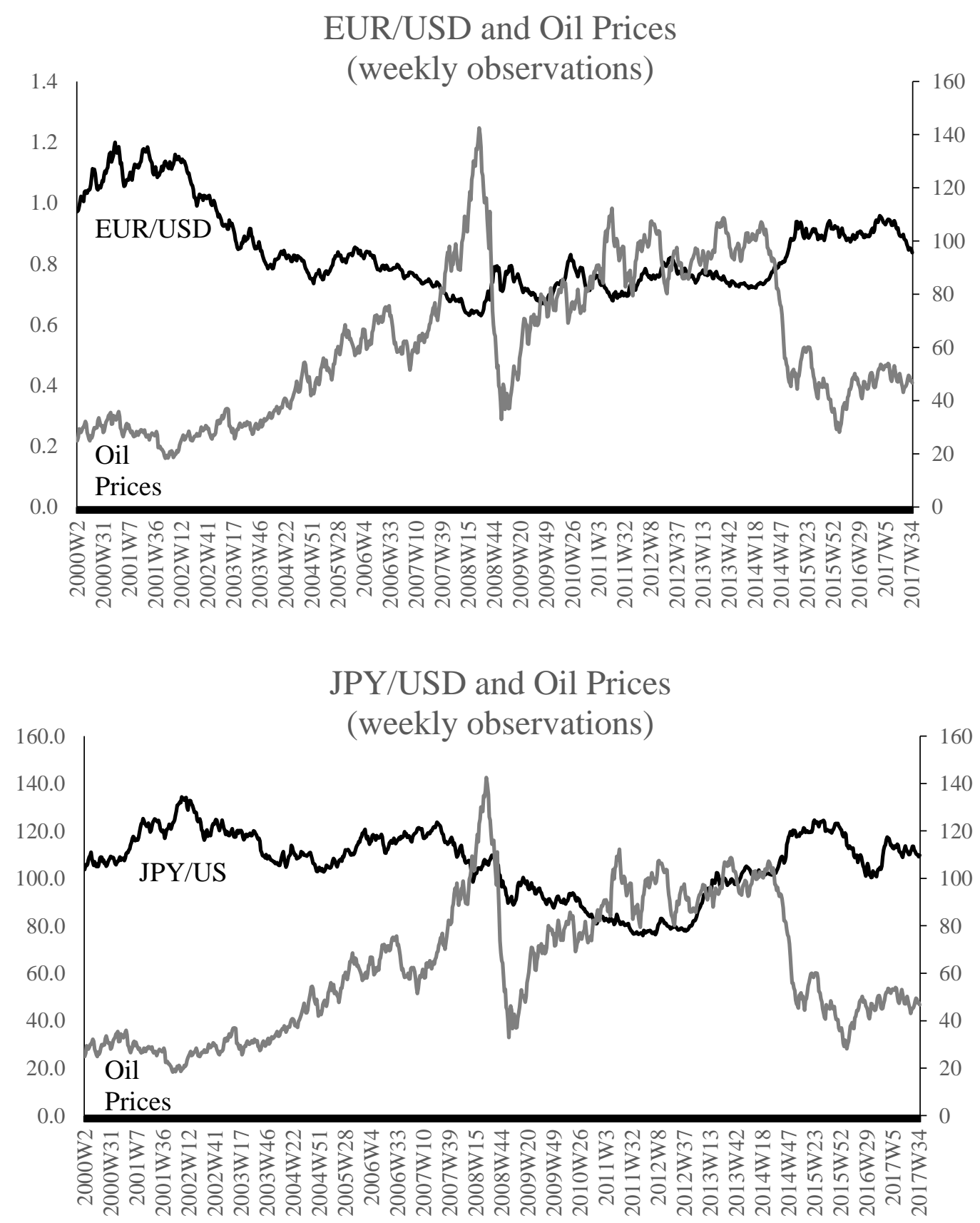

Figure 2: (continued). Weekly Crude oil spot prices (WTI) and major US dollar exchange rates ( $1^{\text {st }}$ January 2000 to $1^{\text {st }}$ September 2017) 


\section{MXN/USD and Oil Prices}

(weekly observations)

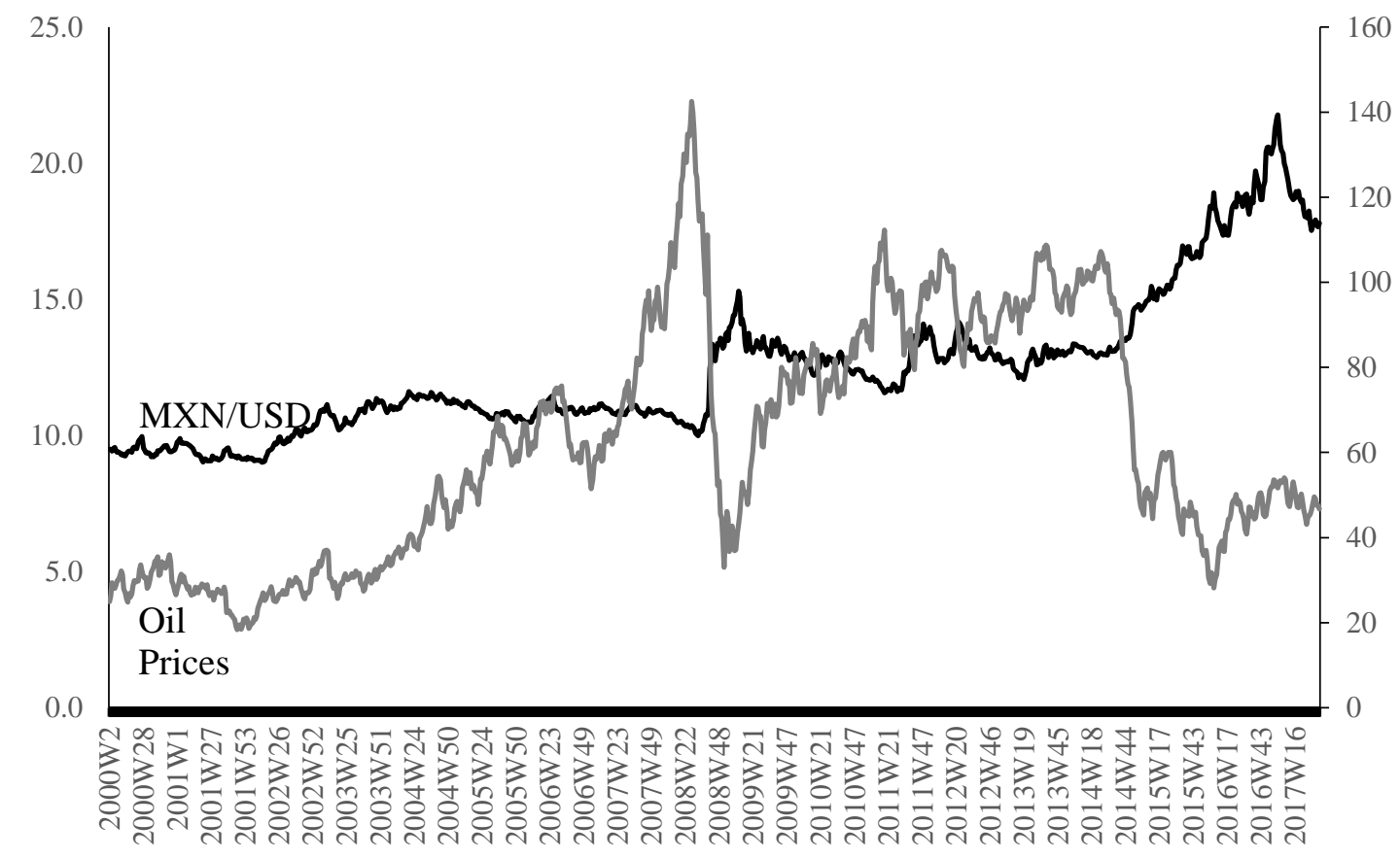

NOK/USD and Oil Prices

(weekly observations)

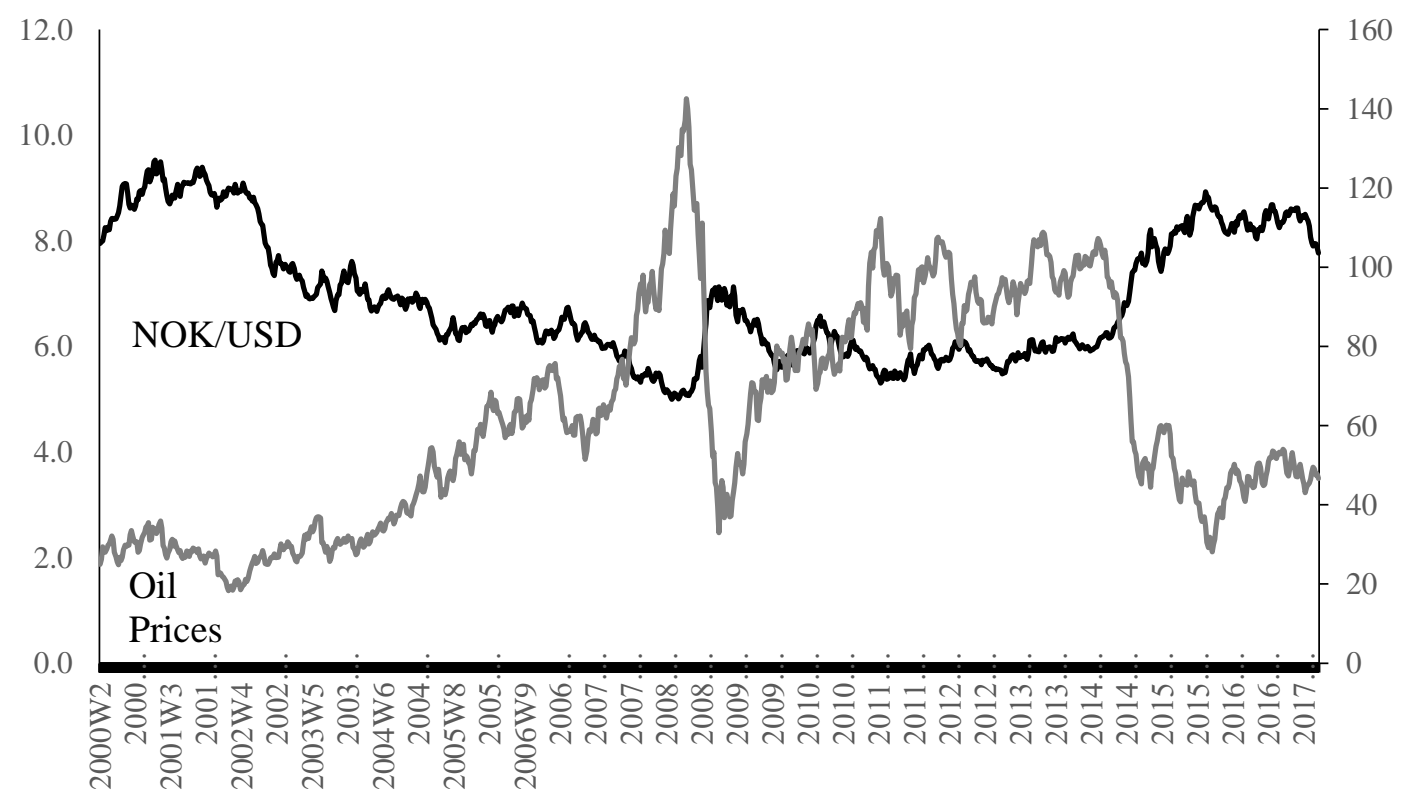

Figure 2: (continued). Weekly Crude oil spot prices (WTI) and major US dollar exchange rates ( $1^{\text {st }}$ January 2000 to $1^{\text {st }}$ September 2017) 


\section{GBT/USD and Oil Prices \\ (weekly observations)}

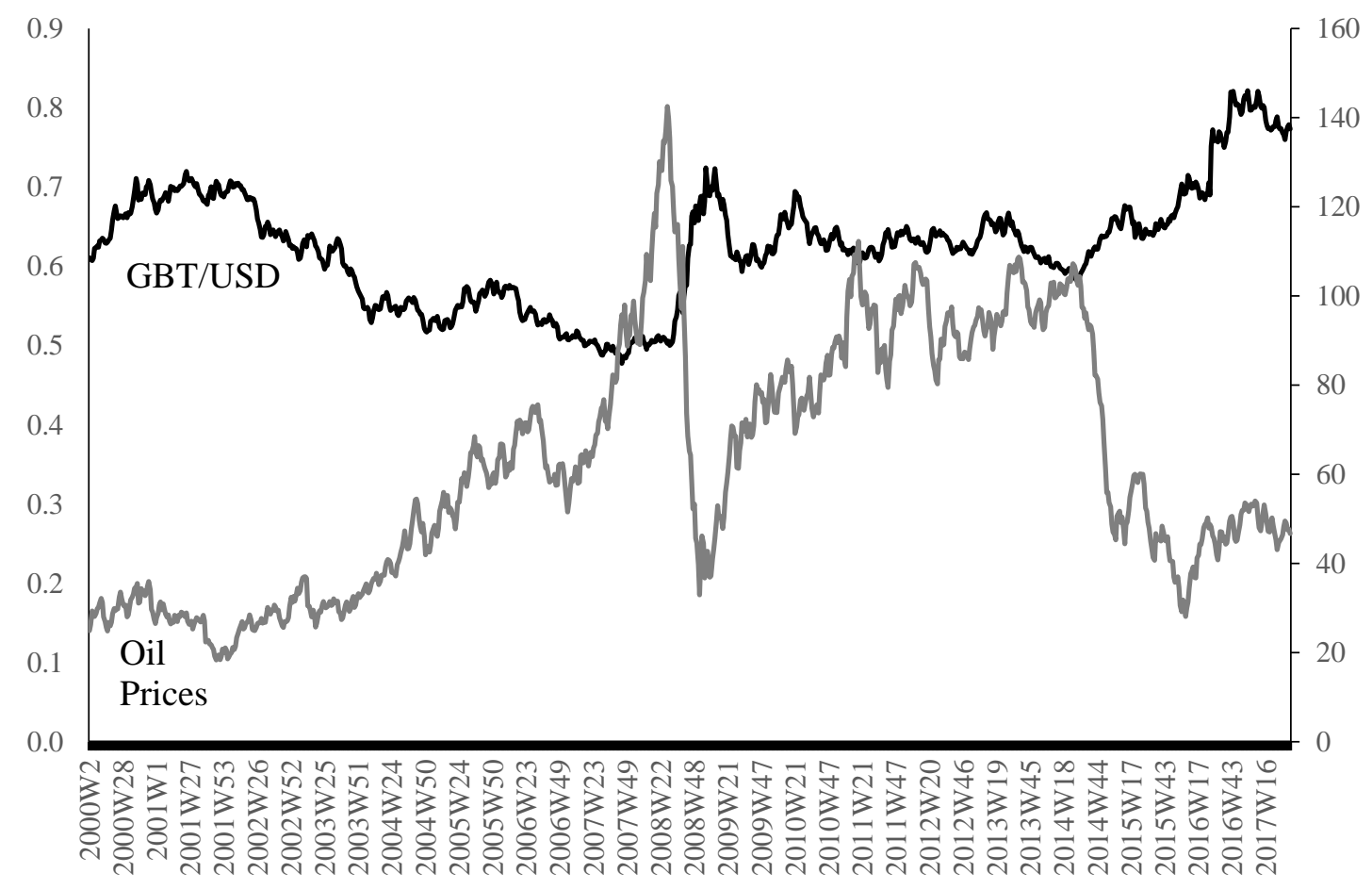

Figure 2: (continued). Weekly Crude oil spot prices (WTI) and major US dollar exchange rates ( $1^{\text {st }}$ January 2000 to $1^{\text {st }}$ September 2017) 


\section{AUD/USD and Oil Prices \\ (monthly observations)}

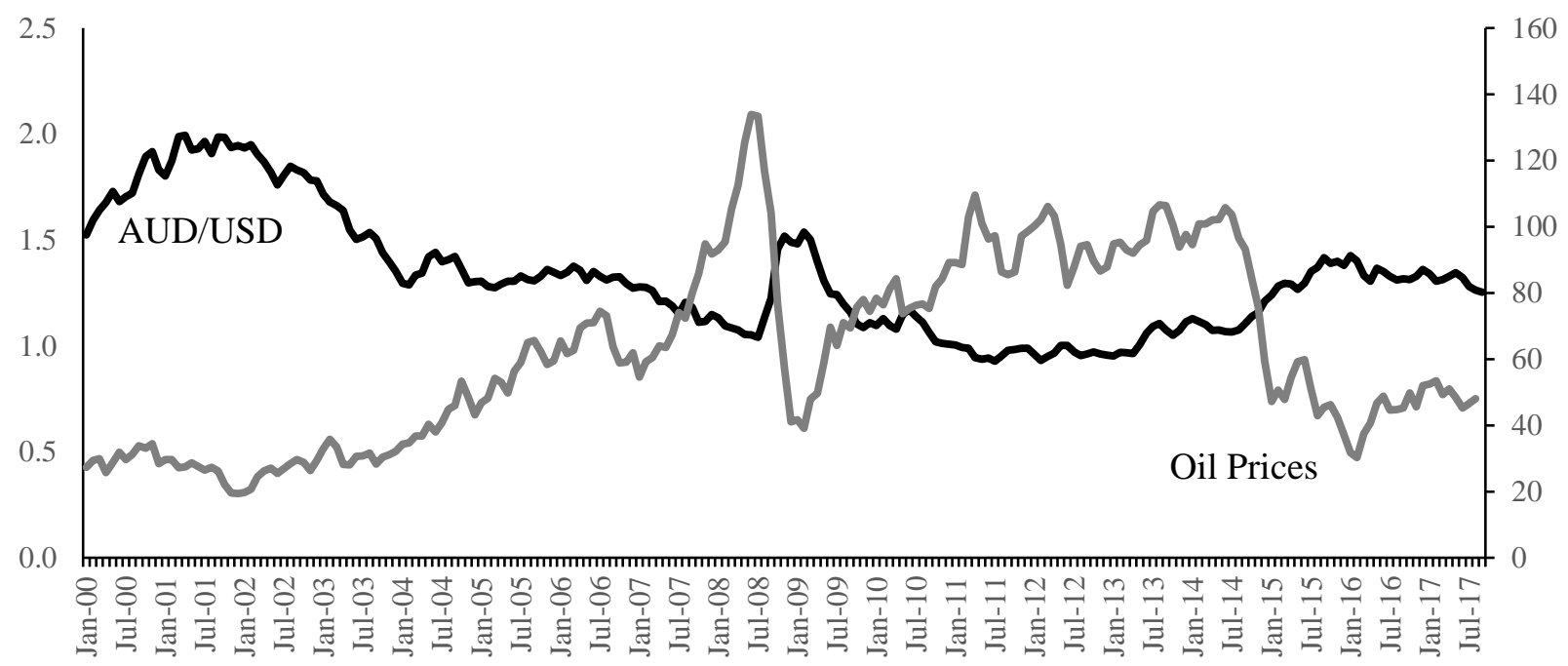

CAD/USD and Oil Prices

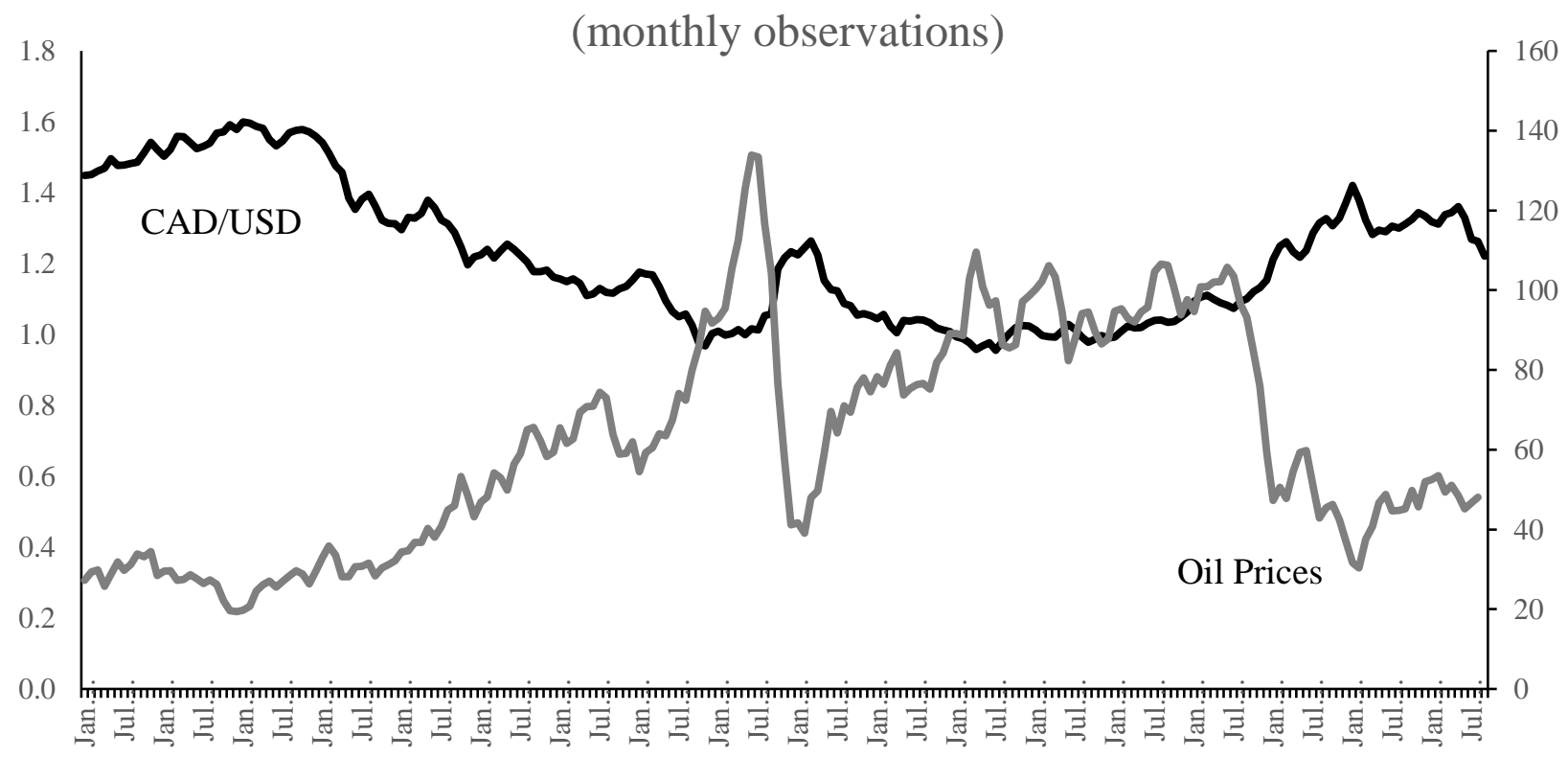

Figure 3: Monthly Crude oil spot prices (WTI) and major US dollar exchange rates $\left(1^{\text {st }}\right.$ January 2000 to $1^{\text {st }}$ September 2017) 


\section{EUR/USD and Oil Prices \\ (monthly observations)}

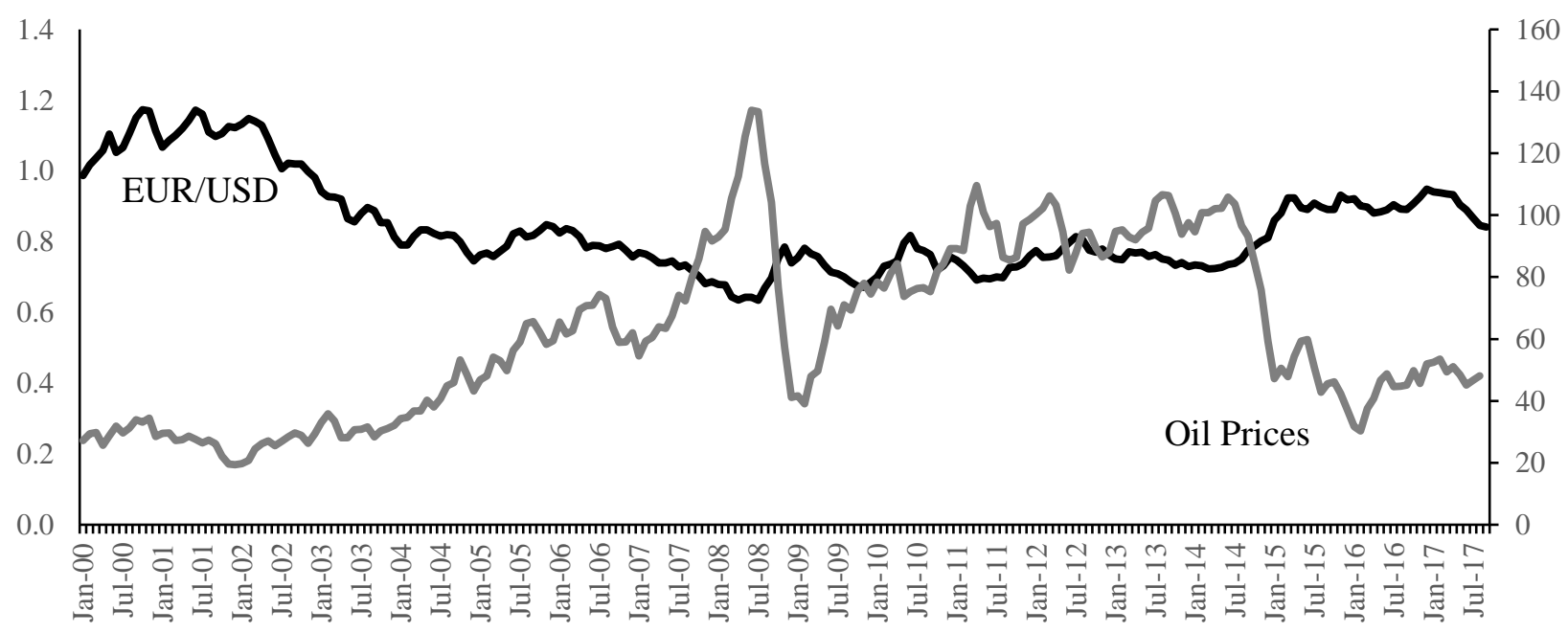

JPY/USD and Oil Prices

(monthly observations)

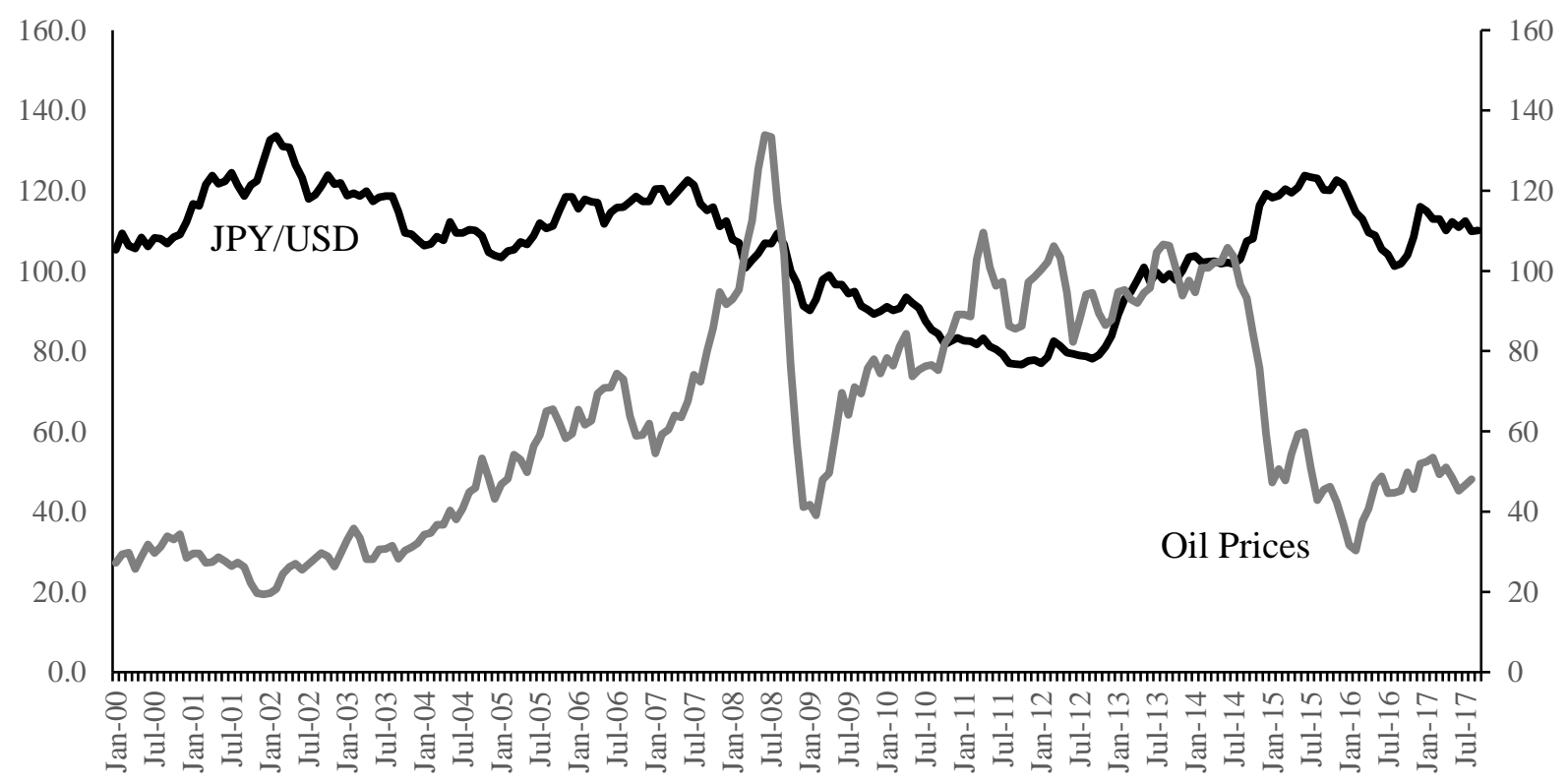

Figure 3: (continued). Monthly Crude oil spot prices (WTI) and major US dollar exchange rates ( $1^{\text {st }}$ January 2000 to $1^{\text {st }}$ September 2017) 


\section{MXN/USD and Oil Prices}

(monthly observations)

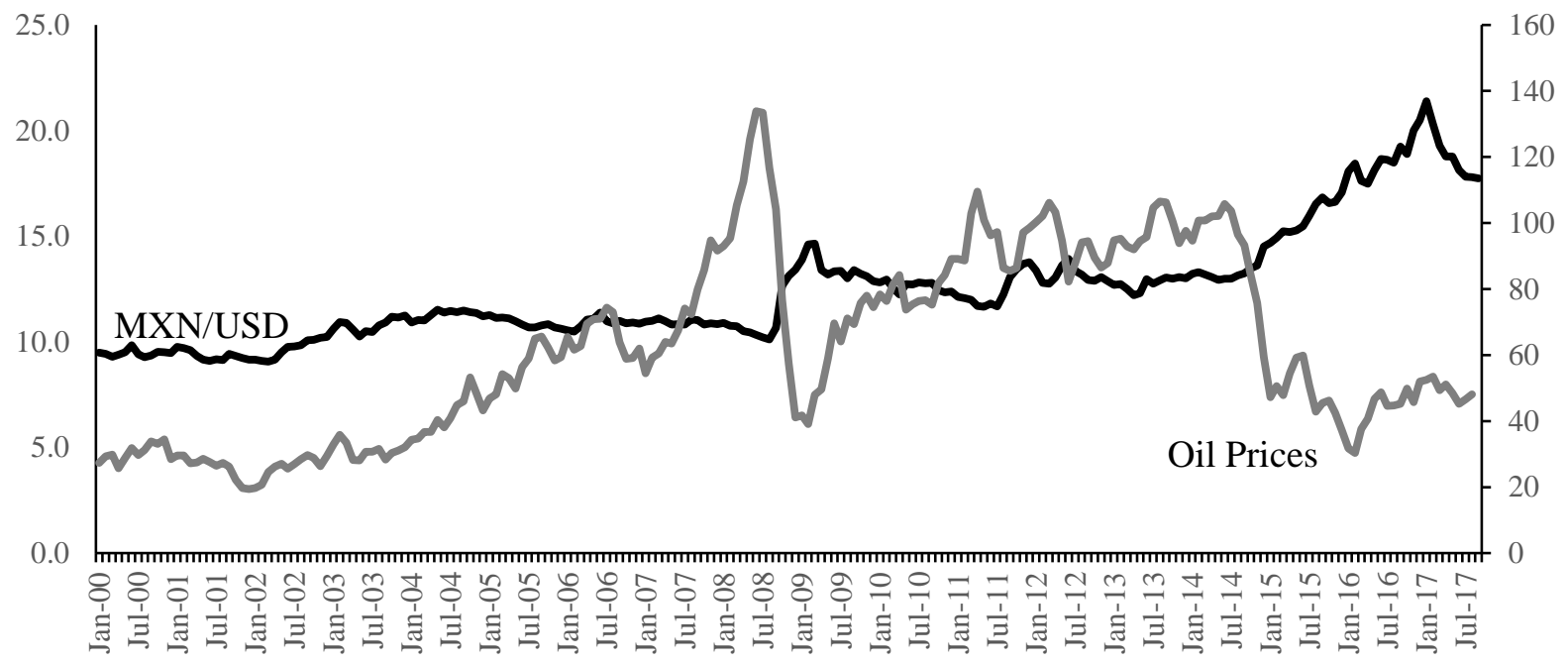

NOK/USD and Oil Prices

(monthly observations)

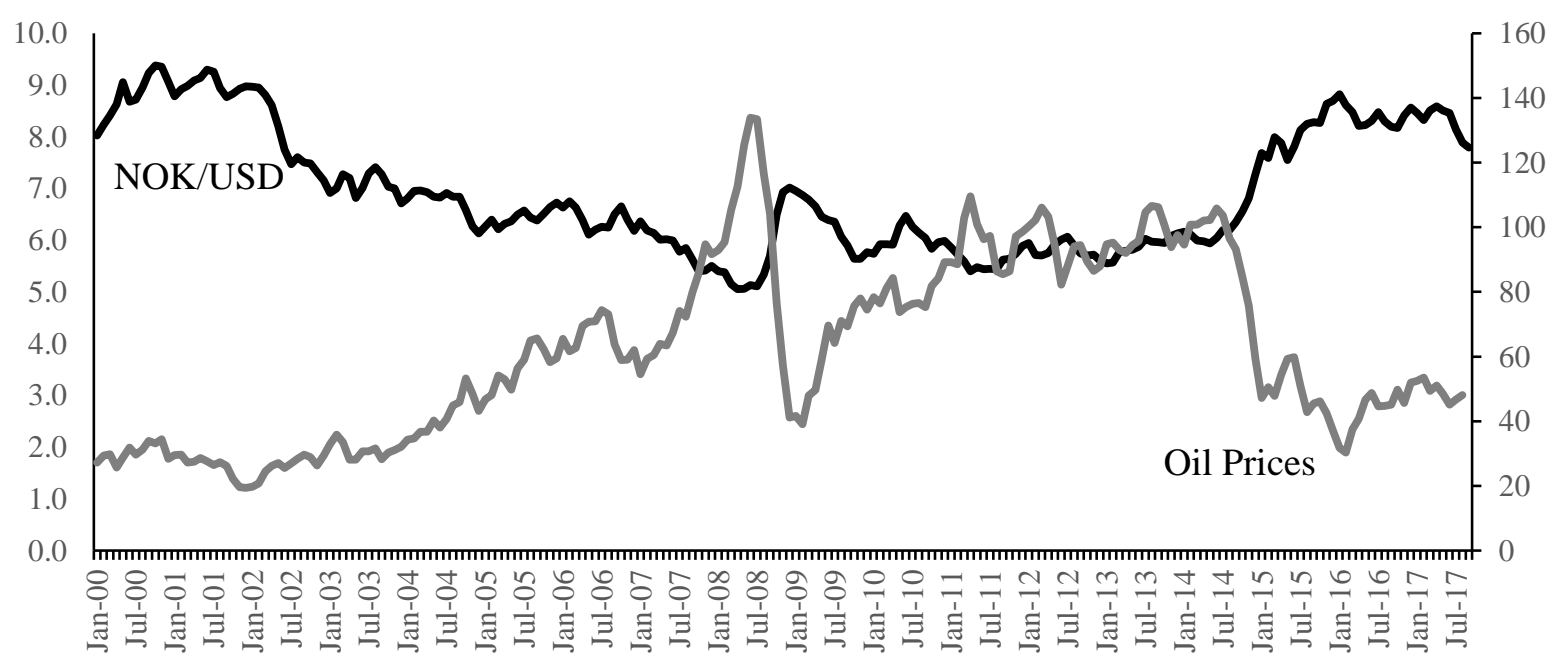

Figure 3: (continued). Monthly Crude oil spot prices (WTI) and major US dollar exchange rates ( $\left(1^{\text {st }}\right.$ January 2000 to $1^{\text {st }}$ September 2017) 


\section{GBT/USD and Oil Prices}

(monthly observations)

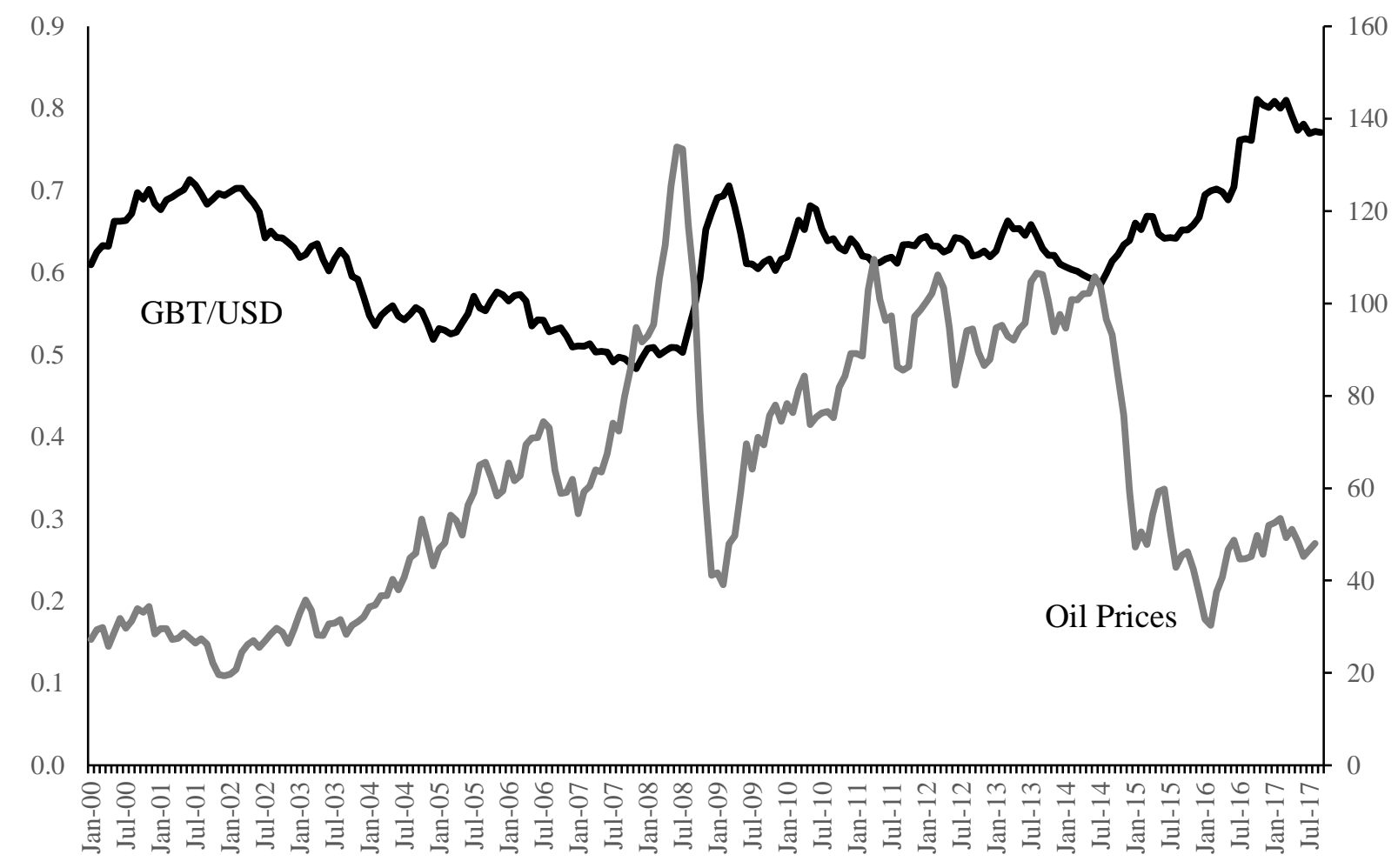

Figure 3: (continued). Monthly Crude oil spot prices (WTI) and major US dollar exchange rates ( $1^{\text {st }}$ January 2000 to $1^{\text {st }}$ September 2017) 


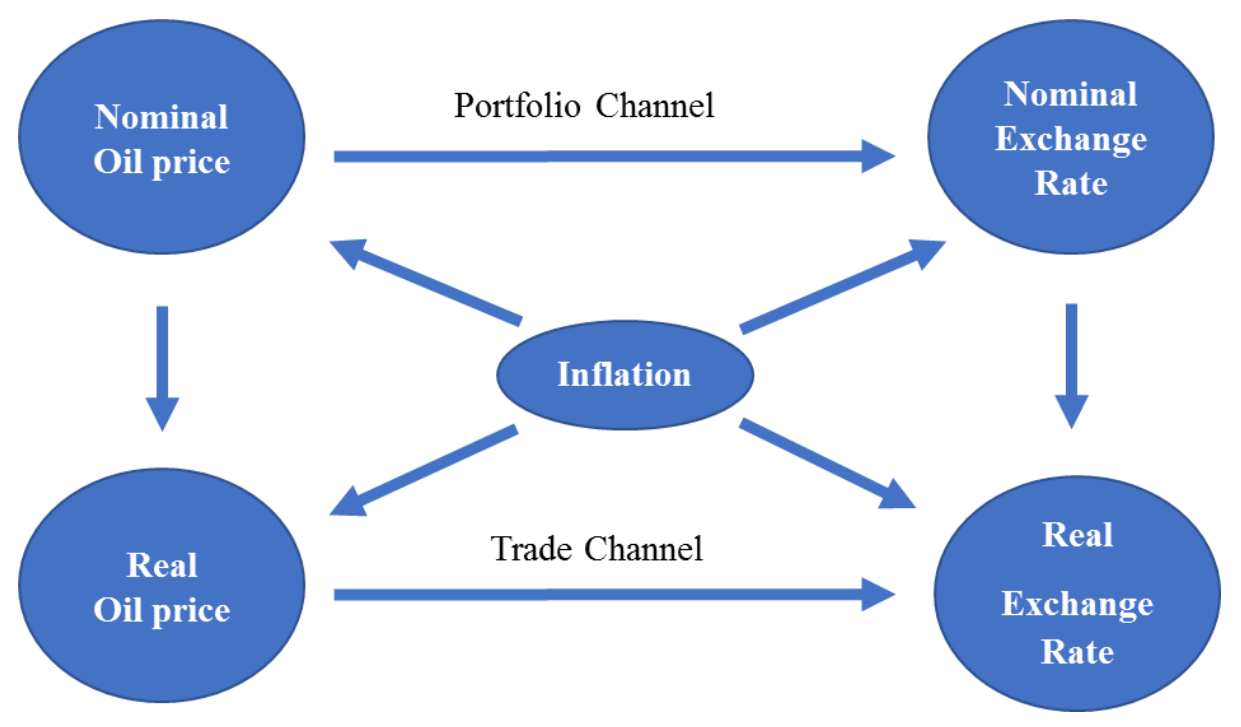

Figure 4: Oil price and exchange rate causalities revised from Beckmann, Czudaj, \& Arora (2017)

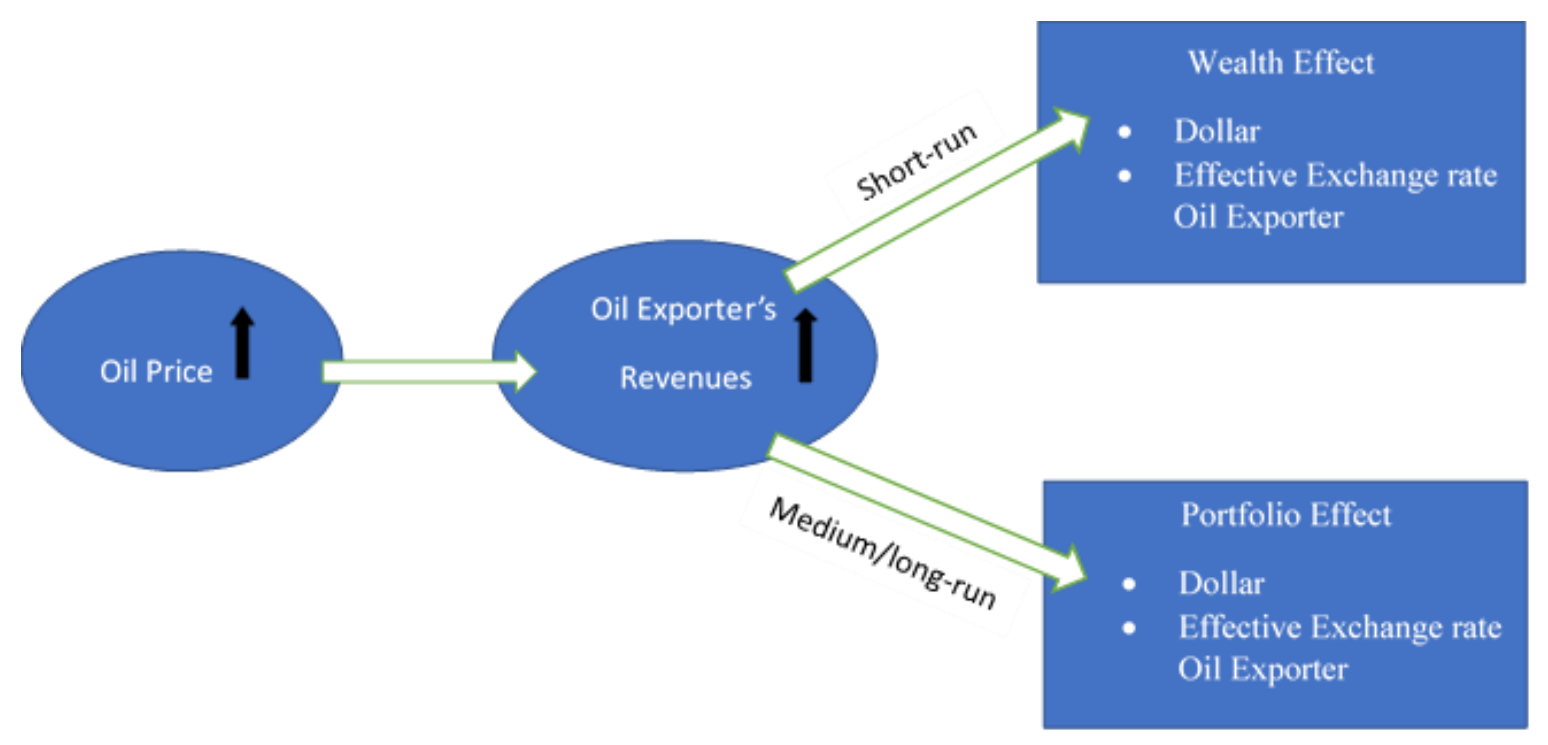

Figure 5: Wealth and Portfolio channel revised from Beckmann, Czudaj, \& Arora (2017) 


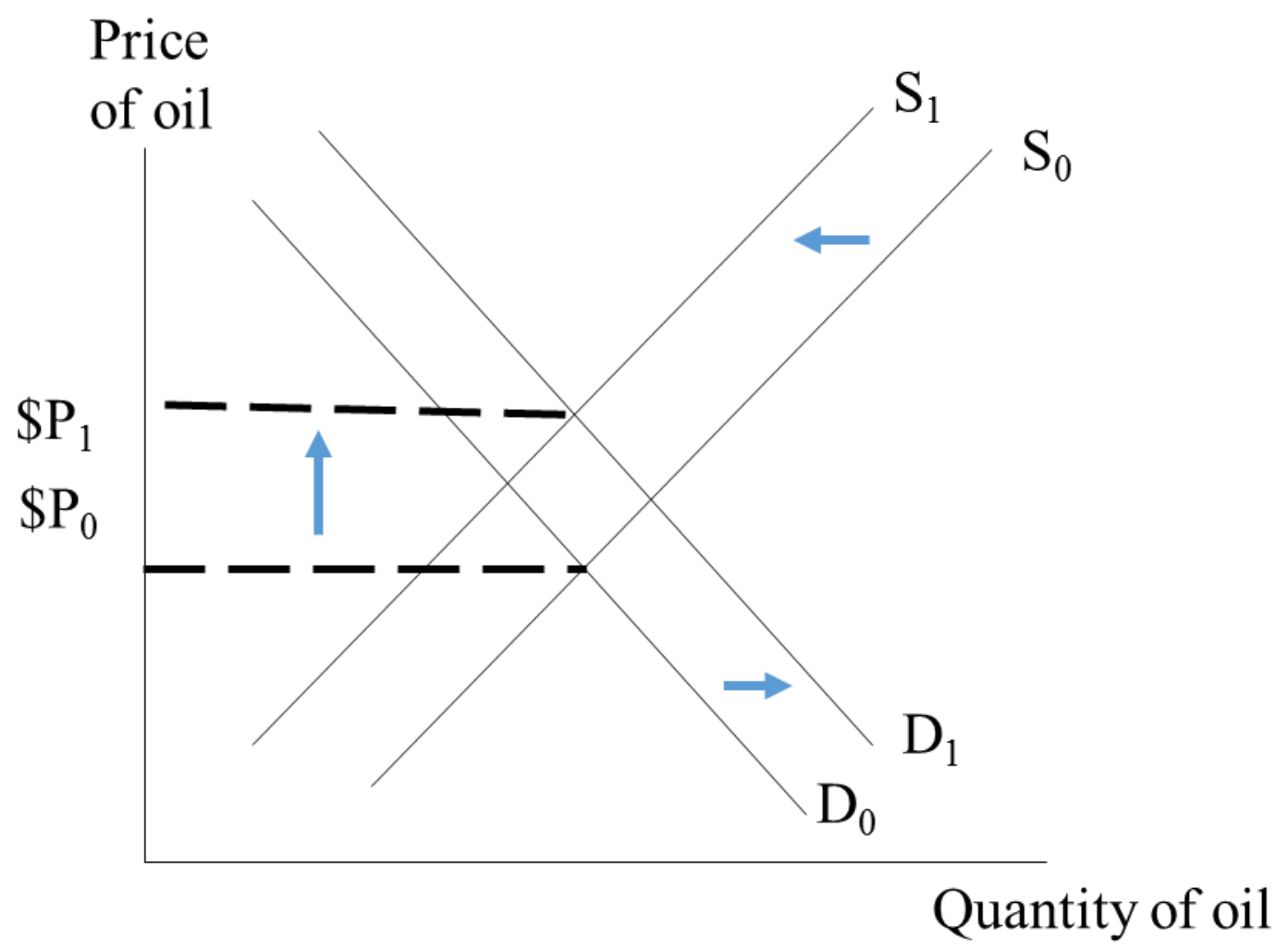

Figure 6: Supply and demand of oil and decline in US dollar revised from Trehan (1986) 
Table 1: Descriptive statistics (Level).

\begin{tabular}{|c|c|c|c|c|c|c|c|c|}
\hline & $\begin{array}{l}\text { Australia } \\
\text { (AUD/ } \\
\text { USD) }\end{array}$ & $\begin{array}{l}\text { Canada } \\
\text { (CAD/ } \\
\text { USD) }\end{array}$ & $\begin{array}{l}\text { Euro } \\
\text { zone } \\
\text { (EUR/ } \\
\text { USD) }\end{array}$ & $\begin{array}{l}\text { Japan } \\
\text { (JPY/ } \\
\text { USD) }\end{array}$ & $\begin{array}{l}\text { Mexico } \\
\text { (MXN/ } \\
\text { USD) }\end{array}$ & $\begin{array}{l}\text { Norway } \\
\text { (NOK/ } \\
\text { USD) }\end{array}$ & $\begin{array}{l}\text { UK } \\
\text { (GBT/ } \\
\text { USD) }\end{array}$ & $\begin{array}{l}\text { Oil } \\
\text { (USD/ } \\
\text { Barrel) }\end{array}$ \\
\hline Mean & 1.32 & 1.22 & .84 & 106.13 & 12.42 & 6.90 & .62 & 62.05 \\
\hline Std.dev & .28 & .19 & .13 & 13.96 & 2.67 & 1.19 & .07 & 27.78 \\
\hline $\begin{array}{l}\text { Coef. } \\
\text { variation }\end{array}$ & .21 & .15 & .15 & .13 & .21 & .17 & .11 & .45 \\
\hline Minimum & .91 & .92 & .62 & 75.72 & 8.95 & 4.95 & .47 & 17.5 \\
\hline Maximum & 2.07 & 1.61 & 1.21 & 134.77 & 21.89 & 9.59 & .82 & 145.31 \\
\hline Median & 1.30 & 1.19 & .80 & 108.44 & 11.62 & 6.54 & .63 & 58.34 \\
\hline skewness & .76 & .46 & .93 & -.54 & 1.24 & .54 & .23 & .35 \\
\hline Pro(skewness) & .00 & .00 & .00 & .00 & .00 & .00 & .00 & .00 \\
\hline kurtosis & 2.75 & 1.99 & 2.97 & 2.41 & 4.12 & 2.00 & 2.95 & 2.05 \\
\hline Pro(kurtosis) & .00 & .00 & .75 & .00 & .00 & .00 & .57 & .00 \\
\hline Observations & 4441 & 4441 & 4441 & 4441 & 4441 & 4441 & 4441 & 4439 \\
\hline
\end{tabular}

Note: All variables from 3 January 2000 to $1^{\text {st }}$ September 2017 and presented in level form.

Table 2: Descriptive statistics (LOG).

\begin{tabular}{lllllllll}
\hline & $\begin{array}{l}\text { Australia } \\
\text { (AUD/ }\end{array}$ & $\begin{array}{l}\text { Canada } \\
\text { (CAD/ } \\
\text { USD) }\end{array}$ & $\begin{array}{l}\text { Euro } \\
\text { Zone } \\
\text { (EUR/ }\end{array}$ & $\begin{array}{l}\text { Japan } \\
\text { (JPY } \\
\text { (USD) }\end{array}$ & $\begin{array}{l}\text { Mexico } \\
\text { (MXN/ } \\
\text { USD) }\end{array}$ & $\begin{array}{l}\text { Norway } \\
\text { (NOK/ } \\
\text { USD) }\end{array}$ & $\begin{array}{l}\text { UK } \\
\text { (GBT/ } \\
\text { USD) }\end{array}$ & $\begin{array}{l}\text { Oil } \\
\text { (USD/ } \\
\text { Barrel) }\end{array}$ \\
\hline Mean & .26 & .19 & -.18 & 4.65 & 2.50 & 1.92 & -.48 & 4.02 \\
Std.dev & .21 & .15 & .15 & .14 & .20 & .17 & .12 & .48 \\
Coef. & .81 & .79 & .83 & .03 & .08 & .09 & .25 & .12 \\
variation & & & & & & & & \\
Minimum & -.10 & -.09 & -.47 & 4.33 & 2.19 & 1.60 & -.75 & 2.86 \\
Maximum & .73 & .48 & .19 & 4.90 & 3.09 & 2.26 & -.19 & 4.99 \\
Median & .26 & .17 & -.23 & 4.69 & 2.45 & 1.88 & -.46 & 4.07 \\
skewness & .39 & .29 & .67 & -.77 & .79 & .35 & -.08 & -.25 \\
Pro(skewness) & .00 & .00 & .00 & .00 & .00 & .00 & .03 & .00 \\
kurtosis & 2.35 & 1.83 & 2.62 & 2.65 & 3.13 & 1.90 & 2.69 & 1.92 \\
Pro(kurtosis) & .00 & .00 & .00 & .00 & .07 & .00 & .00 & .00 \\
Observations & 4441 & 4441 & 4441 & 4441 & 4441 & 4441 & 4441 & 4439 \\
\hline Note: All variabl
\end{tabular}

Note: All variables are from 3 January 2000 to $1^{\text {st }}$ September 2017 and presented in logarithmic form. 
Table 3: Descriptive statistics (Returns).

\begin{tabular}{|c|c|c|c|c|c|c|c|c|}
\hline & $\begin{array}{l}\text { Australia } \\
\text { (AUD/ } \\
\text { USD) }\end{array}$ & $\begin{array}{l}\text { Canada } \\
\text { (CAD/ } \\
\text { USD) }\end{array}$ & $\begin{array}{l}\text { Euro } \\
\text { zone } \\
\text { (EUR/ } \\
\text { USD) }\end{array}$ & $\begin{array}{l}\text { Japan } \\
\text { (JPY/ } \\
\text { USD) }\end{array}$ & $\begin{array}{l}\text { Mexico } \\
\text { (MXN/ } \\
\text { USD) }\end{array}$ & $\begin{array}{l}\text { Norway } \\
\text { (NOK/ } \\
\text { USD) }\end{array}$ & $\begin{array}{l}\text { UK } \\
\text { (GBT/ } \\
\text { USD) }\end{array}$ & $\begin{array}{l}\text { Oil } \\
\text { (USD/ } \\
\text { Barrel) }\end{array}$ \\
\hline Mean & -.02 & -.02 & -.02 & .00 & .07 & -.00 & .02 & .07 \\
\hline Std.dev & 1.43 & 1.04 & 1.14 & 1.12 & 1.21 & 1.33 & 1.10 & 4.29 \\
\hline $\begin{array}{l}\text { Coef. } \\
\text { variation }\end{array}$ & 71.5 & 52 & 57 & 1,120 & 17.28 & 1,330 & 55 & 61.28 \\
\hline Minimum & -6.12 & -6.54 & -6.58 & -4.80 & -6.71 & -5.37 & -3.33 & -19.24 \\
\hline Maximum & 13.23 & 6.42 & 4.37 & 4.80 & 12.31 & 6.61 & 8.54 & 22.14 \\
\hline Median & -.09 & -.04 & -.02 & .03 & 11.62 & -.05 & -.03 & .32 \\
\hline skewness & 1.14 & .28 & .01 & -.08 & 1.24 & .34 & 1.05 & -.39 \\
\hline Pro(skewness) & .00 & .00 & .86 & .30 & .00 & .00 & .00 & .00 \\
\hline kurtosis & 12.00 & 7.18 & 4.45 & 4.24 & 16.13 & 4.05 & 8.98 & 5.58 \\
\hline Pro(kurtosis) & .00 & .00 & .00 & .00 & .00 & .00 & .00 & .00 \\
\hline Observations & 4441 & 4441 & 4441 & 4441 & 4441 & 4441 & 4441 & 4439 \\
\hline
\end{tabular}

Note: All variables are from 3 January 2000 to $1^{\text {st }}$ September 2017 and presented in Returns form. 
Table 4: Correlation matrix (Level)

\begin{tabular}{|c|c|c|c|c|c|c|c|c|}
\hline & $\begin{array}{l}\text { Australia } \\
\text { (AUD/ } \\
\text { USD) }\end{array}$ & $\begin{array}{l}\text { Canada } \\
\text { (CAD/ } \\
\text { USD) }\end{array}$ & $\begin{array}{l}\text { Euro } \\
\text { zone } \\
\text { (EUR/ } \\
\text { USD) }\end{array}$ & $\begin{array}{l}\text { Japan } \\
\text { (JPY/ } \\
\text { USD) }\end{array}$ & $\begin{array}{l}\text { Mexico } \\
\text { (MXN/ } \\
\text { USD) }\end{array}$ & $\begin{array}{l}\text { Norway } \\
\text { (NOK/ } \\
\text { USD) }\end{array}$ & $\begin{array}{l}\text { UK } \\
\text { (GBT/ } \\
\text { USD) }\end{array}$ & $\begin{array}{l}\text { Oil } \\
\text { (USD/ } \\
\text { Barrel) }\end{array}$ \\
\hline $\begin{array}{l}\text { Australia } \\
\text { (AUD/USD) }\end{array}$ & 1 & & & & & & & \\
\hline $\begin{array}{l}\text { Canada } \\
\text { (CAD/USD) }\end{array}$ & $.95 * * *$ & 1 & & & & & & \\
\hline $\begin{array}{l}\text { Euro zone } \\
\text { (EUR/USD) }\end{array}$ & $.88 * * *$ & $.90 * * *$ & 1 & & & & & \\
\hline $\begin{array}{l}\text { Japan } \\
\text { (JPY/USD) }\end{array}$ & $.69 * * *$ & $.68 * * *$ & $.57 * * *$ & 1 & & & & \\
\hline $\begin{array}{l}\text { Mexico } \\
\text { (MXN/USD) }\end{array}$ & $-.35 * * *$ & $-.17 * * *$ & $.16 * * *$ & $-17 * * *$ & 1 & & & \\
\hline $\begin{array}{l}\text { Norway } \\
\text { (NOK/USD) }\end{array}$ & $.81 * * *$ & $.87 * * *$ & $.92 * * *$ & $.59 * * *$ & $.14 * * *$ & 1 & & \\
\hline $\begin{array}{l}\text { UK } \\
\text { (GBT/USD) }\end{array}$ & $.32 * * *$ & $.43 * * *$ & $.56 * * *$ & -.00 & $.54 * * *$ & $.66 * * *$ & 1 & \\
\hline $\begin{array}{l}\text { Oil } \\
\text { (USD/Barrel) }\end{array}$ & $-.85 * * *$ & $-.90 * * *$ & $.79 * * * *$ & $.62 * * *$ & $.09 * * *$ & $-.82 * * *$ & $.36 * * *$ & 1 \\
\hline
\end{tabular}

Note: All variables are daily variables from January 2000 to September 2017 and presented in level form. ${ }^{*} \mathrm{p}<.05, * * \mathrm{p}<.01, * * * \mathrm{p}<.00$ 
Table 5: Correlation matrix $(\log )$

\begin{tabular}{|c|c|c|c|c|c|c|c|c|}
\hline & $\begin{array}{l}\text { Australia } \\
\text { (AUD/ } \\
\text { USD) }\end{array}$ & $\begin{array}{l}\text { Canada } \\
\text { (CAD/ } \\
\text { USD) }\end{array}$ & $\begin{array}{l}\text { Euro } \\
\text { zone } \\
\text { (EUR/ } \\
\text { USD) }\end{array}$ & $\begin{array}{l}\text { Japan } \\
\text { (JPY/ } \\
\text { USD) }\end{array}$ & $\begin{array}{l}\text { Mexico } \\
\text { (MXN/ } \\
\text { USD) }\end{array}$ & $\begin{array}{l}\text { Norway } \\
\text { (NOK/ } \\
\text { USD) }\end{array}$ & $\begin{array}{l}\text { UK } \\
\text { (GBT/ } \\
\text { USD) }\end{array}$ & $\begin{array}{l}\text { Oil } \\
\text { (USD/ } \\
\text { Barrel) }\end{array}$ \\
\hline $\begin{array}{l}\text { Australia } \\
\text { (AUD/USD) }\end{array}$ & 1 & & & & & & & \\
\hline $\begin{array}{l}\text { Canada } \\
\text { (CAD/USD) }\end{array}$ & $.95 * * *$ & 1 & & & & & & \\
\hline $\begin{array}{l}\text { Euro zone } \\
\text { (EUR/USD) }\end{array}$ & $.85 * * *$ & $.89 * * *$ & 1 & & & & & \\
\hline $\begin{array}{l}\text { Japan } \\
\text { (JPY/USD) }\end{array}$ & $.72 * * *$ & $.69 * * *$ & $.55 * * *$ & 1 & & & & \\
\hline $\begin{array}{l}\text { Mexico } \\
\text { (MXN/USD) }\end{array}$ & $-.39 * * *$ & $-.22 * * * *$ & $.21 * * *$ & $-23 * * *$ & 1 & & & \\
\hline $\begin{array}{l}\text { Norway } \\
\text { (NOK/USD) }\end{array}$ & $.82 * * *$ & $.89 * * *$ & $.92 * * *$ & $.59 * * *$ & $.06 * *$ & $\mathbf{1}$ & & \\
\hline $\begin{array}{l}\text { UK } \\
\text { (GBT/USD) }\end{array}$ & $.30 * * *$ & $.42 * * *$ & $.58 * * *$ & -.03 & $.46 * * *$ & $.65 * * *$ & 1 & \\
\hline $\begin{array}{l}\text { Oil } \\
\text { (USD/Barrel) }\end{array}$ & $-.91 * * *$ & $-.95 * * *$ & $.85 * * *$ & $-62 * * *$ & $.26 * * *$ & $-.84 * * *$ &. & 1 \\
\hline
\end{tabular}

Note: All variables are daily variables from January 2000 to September 2017 and presented in $\log$ form. $* \mathrm{p}<.05, * * \mathrm{p}<.01, * * * \mathrm{p}<.001$ 
Table 6: Correlation matrix (Returns)

\begin{tabular}{|c|c|c|c|c|c|c|c|c|}
\hline & $\begin{array}{l}\text { Australia } \\
\text { (AUD/ } \\
\text { USD) }\end{array}$ & $\begin{array}{l}\text { Canada } \\
\text { (CAD/ } \\
\text { USD) }\end{array}$ & $\begin{array}{l}\text { Euro } \\
\text { zone } \\
\text { (EUR/ } \\
\text { USD) }\end{array}$ & $\begin{array}{l}\text { Japan } \\
\text { (JPY/ } \\
\text { USD) }\end{array}$ & $\begin{array}{l}\text { Mexico } \\
\text { (MXN/ } \\
\text { USD) }\end{array}$ & $\begin{array}{l}\text { Norway } \\
\text { (NOK/ } \\
\text { USD) }\end{array}$ & $\begin{array}{l}\text { UK } \\
\text { (GBT/ } \\
\text { USD) }\end{array}$ & $\begin{array}{l}\text { Oil } \\
\text { (USD/ } \\
\text { Barrel) }\end{array}$ \\
\hline $\begin{array}{l}\text { Australia } \\
\text { (AUD/USD) }\end{array}$ & 1 & & & & & & & \\
\hline $\begin{array}{l}\text { Canada } \\
\text { (CAD/USD) }\end{array}$ & $.70 * * *$ & 1 & & & & & & \\
\hline $\begin{array}{l}\text { Euro zone } \\
\text { (EUR/USD) }\end{array}$ & $.58 * * *$ & $.47 * * *$ & 1 & & & & & \\
\hline $\begin{array}{l}\text { Japan } \\
\text { (JPY/USD) }\end{array}$ & .04 & .00 & $.25 * * *$ & $\mathbf{1}$ & & & & \\
\hline $\begin{array}{l}\text { Mexico } \\
\text { (MXN/USD) }\end{array}$ & $.50 * * *$ & $.44 * * *$ & $.23 * * *$ & $.14 * * *$ & 1 & & & \\
\hline $\begin{array}{l}\text { Norway } \\
\text { (NOK/USD) }\end{array}$ & $.63 * * *$ & $.57 * * *$ & $.79 * * *$ & $.16 * * *$ & $.36 * * *$ & $\mathbf{1}$ & & \\
\hline $\begin{array}{l}\text { UK } \\
\text { (GBT/USD) }\end{array}$ & $.53 * * *$ & $.47 * * *$ & $.64 * * *$ & $.07 * *$ & $.26 * * * *$ & $.59 * * *$ & 1 & \\
\hline $\begin{array}{l}\text { Oil } \\
\text { (USD/Barrel) }\end{array}$ & $-.31 * * *$ & $-.38 * * * *$ & $.19 * * *$ & $.06 * *$ & $-.23 * * *$ & $-.38 * * * *$ & $.19 * * *$ & 1 \\
\hline
\end{tabular}

Note: All variables are daily variables from January 2000 to September 2017 and presented in Returns form. ${ }^{*} \mathrm{p}<.05, * * \mathrm{p}<.01, * * * \mathrm{p}<.001$ 
Table 7: Correlation matrix (Returns) between oil prices and USD exchange rates for different time periods

\begin{tabular}{|c|c|c|c|c|c|c|c|c|}
\hline & $\begin{array}{l}\text { Australia } \\
\text { (AUD/ } \\
\text { USD) }\end{array}$ & $\begin{array}{l}\text { Canada } \\
\text { (CAD/ } \\
\text { USD) }\end{array}$ & $\begin{array}{l}\text { Euro } \\
\text { zone } \\
\text { (EUR/ } \\
\text { USD) }\end{array}$ & $\begin{array}{l}\text { Japan } \\
\text { (JPY/ } \\
\text { USD) }\end{array}$ & $\begin{array}{l}\text { Mexico } \\
\text { (MXN/ } \\
\text { USD) }\end{array}$ & $\begin{array}{l}\text { Norway } \\
\text { (NOK/ } \\
\text { USD) }\end{array}$ & $\begin{array}{l}\text { UK } \\
\text { (GBT/ } \\
\text { USD) }\end{array}$ & $\begin{array}{l}\text { Oil } \\
\text { (USD/ } \\
\text { Barrel) }\end{array}$ \\
\hline $\begin{array}{l}\text { Daily Oil } \\
\text { (USD/Barrel) }\end{array}$ & $-.31 * * *$ & $-.38 * * *$ & $-.19 * * *$ & $.06 * *$ & $-.23 * * *$ & $-.38 * * *$ & $-.19 * * *$ & 1 \\
\hline $\begin{array}{l}\text { Weekly Oil } \\
\text { (USD/Barrel }\end{array}$ & $-.31 * * *$ & $-.38 * * *$ & $-.19 * * *$ & $.06 * *$ & $-.23 * * *$ & $-.38 * * *$ & $-.19 * * *$ & 1 \\
\hline $\begin{array}{l}\text { Monthly Oil } \\
\text { (USD/Barrel }\end{array}$ & $-.38 * * *$ & $-.49 * * *$ & $-.27 * * *$ & .07 & $-.32 * * *$ & $-.47 * * *$ & $-.33 * * *$ & 1 \\
\hline
\end{tabular}


Table 8: ADF test for daily observations

\begin{tabular}{|c|c|c|c|c|c|c|c|c|}
\hline & \multicolumn{4}{|l|}{ W/O Trend } & \multicolumn{4}{|l|}{$\mathrm{W} /$ Trend } \\
\hline & $\overline{\operatorname{Lag}(1)}$ & $\operatorname{Lag}(2)$ & $\operatorname{Lag}(4)$ & $\operatorname{Lag}(6)$ & $\operatorname{Lag}(1)$ & $\operatorname{Lag}(2)$ & $\operatorname{Lag}(4)$ & $\operatorname{Lag}(6)$ \\
\hline 1AUD & -1.648 & -1.220 & -1.42 & -1.36 & -.991 & -.991 & -1.53 & -1.44 \\
\hline ICAD & -1.634 & -1.478 & -1.54 & -1.52 & -1.478 & -1.268 & -1.24 & -1.16 \\
\hline 1EUR & -1.891 & -2.539 & -1.61 & -1.59 & -1.640 & -2.469 & -1.46 & -1.44 \\
\hline $1 \mathrm{JPY}$ & -1.968 & -.445 & -1.50 & -1.46 & -1.678 & -.336 & -1.53 & -1.48 \\
\hline $1 \mathrm{MXN}$ & -1.521 & -1.427 & -.57 & -.60 & -1.771 & -.956 & -2.44 & -2.47 \\
\hline INOK & -2.067 & -1.999 & -1.52 & -1.47 & -1.810 & -1.792 & -1.33 & -1.27 \\
\hline IUK & -1.882 & -.809 & -1.20 & -1.18 & -2.189 & -1.305 & -1.53 & -1.50 \\
\hline 1OIL & -2.371 & $-2.837 *$ & -2.06 & -1.95 & -2.407 & -2.071 & -1.79 & -1.67 \\
\hline RAUD & $-34.41 * * *$ & $-23.91 * * *$ & $-30.60 * * *$ & $-25.35^{* * *}$ & $-34.39 * * *$ & $-23.91 * * *$ & $-30.60 * * *$ & $-25.35 * * *$ \\
\hline RCAD & $-34.78 * * *$ & $-21.14 * * *$ & $-31.14 * * *$ & $-25.64 * * *$ & $-34.77 * * *$ & $-21.14 * * *$ & $-31.15^{* * *}$ & $-25.66 * * *$ \\
\hline REUR & $-33.62 * * *$ & $-20.75^{* * *}$ & $-29.94 * * *$ & $-24.26 * * *$ & $-33.62 * * *$ & $-20.75 * * *$ & $-29.94 * * *$ & $-24.27 * * *$ \\
\hline RJPY & $-32.16^{* * *}$ & $-19.71 * * *$ & $-30.69 * * *$ & $-25.36 * * *$ & $-32.17 * * *$ & $-19.71 * * *$ & $-30.69 * * *$ & $-25.36 * * *$ \\
\hline RMXN & $-34.99 * * *$ & $-25.00 * * *$ & $-31.86 * * *$ & $-25.59 * * *$ & $-34.98 * * *$ & $-24.98 * * *$ & $-31.86^{* * *}$ & $-25.59 * * *$ \\
\hline RNOK & $-36.54 * * *$ & $-23.78 * * *$ & $-31.33 * * *$ & $-25.57 * * *$ & $-36.54 * * *$ & $-23.78 * * *$ & $-31.35 * * *$ & $-25.60 * * *$ \\
\hline RUK & $-34.17 * * *$ & $-21.43 * * *$ & $-31.66 * * *$ & $-24.88 * * *$ & $-34.16 * * *$ & $-21.41 * * *$ & $-31.67 * * *$ & $-24.89 * * *$ \\
\hline ROIL & $-37.28 * * *$ & $-20.74 * * *$ & $-30.63^{* * *}$ & $-26.97 * * *$ & $-37.26 * * *$ & $-20.71 * * *$ & $-30.64 * * *$ & $-26.99 * * *$ \\
\hline
\end{tabular}

Notes: $(1) * \mathrm{p}<.05, * * \mathrm{p}<.01, * * * \mathrm{p}<.001$

(2) L and R are natural log and first difference of natural log, respectively.

$\operatorname{ROIL}_{(t)}=\left(\operatorname{lOIL}_{(t)}-1 \mathrm{OIL}(\mathrm{t}-1)\right) \times 100$

$\operatorname{REXCH}_{(t)}=\left(\mathrm{lEXCH}_{(\mathrm{t})}-\mathrm{lEXCH}_{(\mathrm{t}-1)}\right) \times 100$

(3) The null and alternative hypotheses are:

$\mathrm{H}_{0}$ : time series sample is non-stationary

$\mathrm{H}_{1}$ : time series sample is stationary 
Table 9: ADF test for weekly observations

\begin{tabular}{|c|c|c|c|c|c|c|c|c|}
\hline & \multicolumn{4}{|l|}{ W/O Trend } & \multicolumn{4}{|l|}{ W/Trend } \\
\hline & $\operatorname{Lag}(1)$ & $\operatorname{Lag}(2)$ & $\operatorname{Lag}(4)$ & $\operatorname{Lag}(6)$ & $\operatorname{Lag}(1)$ & $\operatorname{Lag}(2)$ & $\operatorname{Lag}(4)$ & $\operatorname{Lag}(6)$ \\
\hline$\overline{\text { 1AUD }}$ & -1.50 & -1.40 & -1.41 & -1.64 & -1.78 & $\begin{array}{l}-1.63 \\
\end{array}$ & -1.47 & -1.80 \\
\hline 1CAD & -1.67 & -1.51 & -1.43 & -1.37 & -1.43 & -1.18 & -1.09 & -.93 \\
\hline 1EUR & -1.71 & -1.60 & -1.72 & -1.68 & -1.59 & -1.43 & -1.55 & -1.44 \\
\hline $1 \mathrm{JPY}$ & -1.53 & -1.47 & -1.55 & -1.41 & -1.52 & -1.47 & -1.36 & -1.16 \\
\hline $1 \mathrm{MXN}$ & -.81 & -.93 & -.83 & -.89 & -2.66 & -2.73 & -2.69 & -2.79 \\
\hline INOK & -1.62 & -1.46 & -1.45 & -1.48 & -1.43 & -1.25 & -1.22 & -1.32 \\
\hline IUK & -1.29 & -1.11 & -1.16 & -1.22 & -1.59 & -1.40 & -1.49 & -1.54 \\
\hline 1OIL & -2.07 & -1.88 & -1.99 & -1.96 & -1.97 & -1.80 & -1.88 & -1.90 \\
\hline RAUD & $-19.81 * * *$ & $-15.36 * * *$ & $-12.02 * * *$ & $-10.22 * * *$ & $-19.81 * * *$ & $-15.36 * * *$ & $-12.02 * * *$ & $-10.23 * * *$ \\
\hline RCAD & $-21.57 * * *$ & $-16.67 * * *$ & $-13.47 * * *$ & $-10.09 * * *$ & $-21.59 * * *$ & $-16.70 * * *$ & $-13.51 * * *$ & $-10.15 * * *$ \\
\hline REUR & $-19.52 * * *$ & $-15.40 * * *$ & $-12.57 * * *$ & $-11.04 * * *$ & $-19.53 * * *$ & $-15.41 * * *$ & $-12.60 * * *$ & $-11.06 * * *$ \\
\hline RJPY & $-19.54 * * *$ & $-16.24 * * *$ & $-13.07 * * *$ & -10.80 *** & $-19.54 * * *$ & $-16.23 * * *$ & $-13.07 * * *$ & $-10.81 * * *$ \\
\hline RMXN & $-19.57 * * *$ & $-16.63 * * *$ & $-12.33 * * *$ & $-10.69 * * *$ & $-19.56 * * *$ & $-16.63 * * *$ & $-12.33 * * *$ & $-10.69 * * *$ \\
\hline RNOK & $-20.45^{* * *}$ & $-16.50 * * *$ & $-12.12 * * *$ & $-10.12 * * *$ & $-20.48 * * *$ & $-16.54 * * *$ & $-12.18 * * *$ & $-10.27 * * *$ \\
\hline RUK & $-21.32 * * *$ & $-15.94 * * *$ & $-13.02 * * *$ & $-11.16^{* * * *}$ & $-21.33 * * *$ & $-15.96 * * *$ & $-13.05^{* * *}$ & $-11.18 * * *$ \\
\hline ROIL & $-21.77 * * *$ & $-16.01 * * *$ & $-12.40 * * *$ & $-10.74 * * *$ & $-21.08 * * *$ & $-16.03 * * *$ & $-12.41 * * *$ & $-10.76 * * *$ \\
\hline
\end{tabular}

Table 10: ADF test for monthly observation

\begin{tabular}{|c|c|c|c|c|c|c|c|c|}
\hline & \multicolumn{4}{|c|}{ W/O Trend } & \multicolumn{4}{|l|}{ W/Trend } \\
\hline & $\operatorname{Lag}(1)$ & $\operatorname{Lag}(2)$ & $\operatorname{Lag}(4)$ & $\operatorname{Lag}(6)$ & $\overline{\operatorname{Lag}(1)}$ & $\operatorname{Lag}(2)$ & $\operatorname{Lag}(4)$ & $\operatorname{Lag}(6)$ \\
\hline 1AUD & -1.76 & -1.59 & -1.89 & -1.86 & -1.85 & -1.55 & -1.84 & -1.86 \\
\hline $1 \mathrm{CAD}$ & -1.62 & -1.59 & -1.85 & -1.71 & -1.42 & -1.32 & -1.64 & -1.46 \\
\hline lEUR & -1.90 & -1.82 & -2.22 & -2.10 & -1.70 & -1.54 & -1.85 & -1.78 \\
\hline 1JPY & -1.54 & -1.75 & -1.58 & -1.36 & -1.50 & -1.81 & -1.57 & -1.33 \\
\hline $1 \mathrm{MXN}$ & -.85 & -.77 & -.81 & -.50 & -2.86 & -2.61 & -2.84 & -2.24 \\
\hline INOK & -1.85 & -1.75 & -2.10 & -2.03 & -1.66 & -1.51 & -1.77 & -1.77 \\
\hline IUK & -1.32 & -1.37 & -1.79 & -1.37 & -1.68 & -1.74 & -2.21 & -1.79 \\
\hline 1OIL & -1.99 & -2.08 & -1.91 & -1.82 & -1.89 & -2.03 & -1.72 & -1.43 \\
\hline RAUD & $-9.28 * * *$ & $-7.25 * * *$ & $-5.59 * * *$ & $-5.25 * * *$ & $-9.29 * * *$ & $-7.25 * * *$ & $-5.61 * * *$ & $-5.29 * * *$ \\
\hline RCAD & $-8.68 * * *$ & $-7.35 * * *$ & $-5.21 * * *$ & $-5.33 * * *$ & $-8.72 * * *$ & $-7.59 * * *$ & $-5.25^{* * *}$ & $-5.43 * * *$ \\
\hline REUR & $-9.45 * * *$ & $-7.73 * * *$ & $-6.04 * * *$ & $-5.58 * * *$ & $-9.49 * * *$ & $-7.80 * * *$ & $-6.11 * * *$ & $-5.75 * * *$ \\
\hline RJPY & $-7.88 * * *$ & $-7.27 * * *$ & $-6.77 * * *$ & $-5.64 * * *$ & $-7.87 * * *$ & $-7.25 * * *$ & $-6.75 * * *$ & $-5.64 * * *$ \\
\hline RMXN & $-9.50 * * *$ & $-8.27 * * *$ & $-6.56^{* * *}$ & $-5.48 * * *$ & $-9.49 * * *$ & $-8.27 * * *$ & $-6.59 * * *$ & $-5.46 * * *$ \\
\hline RNOK & $-8.81 * * *$ & $-7.24 * * *$ & $-5.81 * * *$ & $-5.36 * * *$ & $-8.89 * * *$ & $-7.36 * * *$ & $-5.93 * * *$ & $-5.60 * * *$ \\
\hline RUK & $-8.56 * * *$ & $-6.44 * * *$ & $-5.77 * * *$ & $-6.06 * * *$ & $-8.62 * * *$ & $-6.49 * * *$ & $-5.87 * * *$ & $-6.24 * * *$ \\
\hline ROIL & $-8.26 * * *$ & $-7.77 * * *$ & $-6.29 * * *$ & $-6.03 * * *$ & $-8.28 * * *$ & $-7.84 * * *$ & $-6.32 * * *$ & $-6.10 * * *$ \\
\hline
\end{tabular}


Table 11: Johansen tests for cointegration (daily observations from 2000 to 2017)

\begin{tabular}{|c|c|c|c|c|}
\hline & Number of lags & $\begin{array}{l}\text { Number of } \\
\text { cointegration } \\
\text { vectors }\end{array}$ & Trace statistics & $5 \%$ C.V. \\
\hline 1AUD-1OIL & 6 & At most 1 & 2.04 & 3.76 \\
\hline 1CAD-1OIL & 6 & At most 1 & 2.36 & 3.76 \\
\hline 1EUR-1OIL & 2 & At most 1 & 2.39 & 3.76 \\
\hline 1JPY-1OIL & 2 & At most 0 & 11.39 & 15.41 \\
\hline 1MXN-1OIL & 6 & At most 0 & 4.47 & 15.41 \\
\hline 1NOK-1OIL & 6 & At most 1 & 2.94 & 3.76 \\
\hline 1UK- 1OIL & 6 & At most 0 & 7.44 & 15.41 \\
\hline
\end{tabular}

Table 12: Johansen tests for cointegration (weekly observations from 2000 to 2017)

\begin{tabular}{|c|c|c|c|c|}
\hline & Number of lags & $\begin{array}{l}\text { Number of } \\
\text { cointegration } \\
\text { vectors }\end{array}$ & Trace statistics & $5 \%$ C.V. \\
\hline 1AUD-1OIL & 2 & At most 1 & 2.16 & 3.76 \\
\hline 1CAD-1OIL & 3 & At most 1 & 2.15 & 3.76 \\
\hline 1EUR-1OIL & 4 & At most 1 & 3.19 & 3.76 \\
\hline 1JPY-1OIL & 4 & At most 0 & 11.12 & 15.41 \\
\hline 1MXN-1OIL & 2 & At most 0 & 4.47 & 15.41 \\
\hline 1NOK-1OIL & 3 & At most 1 & 3.02 & 3.76 \\
\hline 1UK- 1OIL & 4 & At most 0 & 6.48 & 15.41 \\
\hline
\end{tabular}

Table 13: Johansen tests for cointegration (monthly observations from 2000 to 2017)

\begin{tabular}{|c|c|c|c|c|}
\hline & Number of lags & $\begin{array}{l}\text { Number of } \\
\text { cointegration } \\
\text { vectors }\end{array}$ & Trace statistics & $5 \%$ C.V. \\
\hline 1AUD-1OIL & 3 & At most 1 & 2.68 & 3.76 \\
\hline 1CAD-1OIL & 6 & At most 1 & 3.34 & 3.76 \\
\hline 1EUR-1OIL & 2 & At most 1 & 3.70 & 3.76 \\
\hline 1JPY-1OIL & 2 & At most 0 & 11.25 & 15.41 \\
\hline 1MXN-1OIL & 3 & At most 0 & 6.97 & 15.41 \\
\hline 1NOK-1OIL & 2 & At most 0 & 14.33 & 15.41 \\
\hline 1UK- 1OIL & 2 & At most 0 & 6.87 & 15.41 \\
\hline
\end{tabular}


Table 14: Granger causality test results for daily JPY/USD, MXN/USD, and UK/USD with oil prices.

\begin{tabular}{|c|c|c|c|}
\hline Regression equations (daily) & $\begin{array}{l}\text { \# of } \\
\text { cointegration }\end{array}$ & $\begin{array}{l}\text { F } \\
\text { value }\end{array}$ & results \\
\hline $\begin{array}{l}\text { reg ROIL ROIL(2 lags) RJPY(2 lags), } \\
\text { robust } \\
\text { reg ROIL ROIL(2 lags), robust }\end{array}$ & 0 & $\begin{array}{l}1.03 \\
(.67)\end{array}$ & $\begin{array}{l}\text { JPY/USD does not Granger cause } \\
\text { oil prices }\end{array}$ \\
\hline $\begin{array}{l}\text { reg RJPY RJPY(2 lags) ROIL(2 } \\
\text { lags),robust } \\
\text { reg RJPY RJPY(2 lags) , robust }\end{array}$ & 0 & $\begin{array}{l}1.72 \\
(.35)\end{array}$ & $\begin{array}{l}\text { Oil prices does not Granger cause } \\
\text { JPY/USD }\end{array}$ \\
\hline $\begin{array}{l}\text { reg ROIL ROIL(6 lags) RMXN(6) } \\
\text { lags), robust } \\
\text { reg ROIL ROIL(6 lags), robust }\end{array}$ & 0 & $\begin{array}{l}1.55 \\
(.65)\end{array}$ & $\begin{array}{l}\text { MXN/USD does not Granger } \\
\text { cause oil prices }\end{array}$ \\
\hline $\begin{array}{l}\text { reg RMXN RMXN(6 lags) } \operatorname{ROIL}(6 \\
\text { lags), robust } \\
\text { regress } \\
\text { robust }\end{array}$ & 0 & $\begin{array}{l}.24 \\
(.83)\end{array}$ & $\begin{array}{l}\text { Oil prices does not Granger cause } \\
\text { MXN/USD }\end{array}$ \\
\hline $\begin{array}{l}\text { reg ROIL ROIL(6 lags) RUK(6 lags) } \\
\text {, robust } \\
\text { reg ROIL ROIL(6 lags), robust }\end{array}$ & 0 & $\begin{array}{l}1.88^{*} \\
(.09)\end{array}$ & $\begin{array}{l}\text { UK/USD does not Granger } \\
\text { causes oil prices }\end{array}$ \\
\hline $\begin{array}{l}\text { reg RUK RUK(6 lags) ROIL(6 lags), } \\
\text { robust } \\
\text { reg RUK RUK(6 lags), robust }\end{array}$ & 0 & $\begin{array}{l}1.01 \\
(.42)\end{array}$ & $\begin{array}{l}\text { Oil prices does not Granger cause } \\
\text { UK/USD }\end{array}$ \\
\hline
\end{tabular}

Note: VAR model is used for causality tests. P-values are presented in parenthesis. $* \mathrm{p}<.05, * * \mathrm{p}<.01, * * * \mathrm{p}<.001$ 
Table 15: Granger causality test results for weekly JPY/USD, MXN/USD, and UK/USD with oil prices.

\begin{tabular}{|c|c|c|c|}
\hline Regression equations (weekly) & $\begin{array}{l}\# \text { of } \\
\text { cointegration }\end{array}$ & $\begin{array}{l}\mathrm{F} \\
\text { value }\end{array}$ & results \\
\hline $\begin{array}{l}\text { reg ROIL ROIL(4 lags) } \\
\text { RJPY(4 lags), robust } \\
\text { reg ROIL ROIL(4 lags), robust }\end{array}$ & 0 & $\begin{array}{l}.79 \\
(.53)\end{array}$ & $\begin{array}{l}\text { JPY/USD does not Granger cause oil } \\
\text { prices }\end{array}$ \\
\hline $\begin{array}{l}\text { reg RJPY RJPY(4 lags) ROIL(4 } \\
\text { lags),robust } \\
\text { reg RJPY RJPY(4 lags), robust }\end{array}$ & 0 & $\begin{array}{l}.62 \\
(.64)\end{array}$ & $\begin{array}{l}\text { Oil prices does not Granger cause } \\
\text { JPY/USD }\end{array}$ \\
\hline $\begin{array}{l}\text { reg ROIL ROIL(2 lags) } \\
\text { RMXN(2 lags), robust } \\
\text { reg ROIL ROIL(2 lags), robust }\end{array}$ & 0 & $\begin{array}{l}.88 \\
(.41)\end{array}$ & $\begin{array}{l}\text { MXN/USD does not Granger cause } \\
\text { oil prices }\end{array}$ \\
\hline $\begin{array}{l}\text { reg RMXN RMXN(2 lags) } \\
\text { ROIL(2 lags), robust } \\
\text { regress RMXN RMXN(2 lags), } \\
\text { robust }\end{array}$ & 0 & $\begin{array}{l}.57 \\
(.54)\end{array}$ & $\begin{array}{l}\text { Oil prices does not Granger cause } \\
\text { MXN/USD }\end{array}$ \\
\hline $\begin{array}{l}\text { reg ROIL ROIL(4 lags) RUK(4 } \\
\text { lags), robust } \\
\text { reg ROIL ROIL(4 lags), robust }\end{array}$ & 0 & $\begin{array}{l}2.18^{*} \\
(.07)\end{array}$ & $\begin{array}{l}\text { UK/USD does not Granger causes oil } \\
\text { prices }\end{array}$ \\
\hline $\begin{array}{l}\text { reg RUK RUK(4 lags) ROIL(4 } \\
\text { lags), robust } \\
\text { reg RUK RUK(4 lags), robust }\end{array}$ & 0 & $\begin{array}{l}1.55 \\
(.18)\end{array}$ & $\begin{array}{l}\text { Oil prices does not Granger cause } \\
\text { UK/USD }\end{array}$ \\
\hline
\end{tabular}

Note: VAR model is used for causality tests. P-values are presented in parenthesis. $* \mathrm{p}<.05,{ }^{* *} \mathrm{p}<.01, * * * \mathrm{p}<.001$ 
Table 16: Granger causality test results for monthly JPY/USD, MXN/USD, NOK/USD, and UK/USD with oil prices.

$\begin{array}{lrr}\# & \text { of } & \text { F-value results } \\ \text { cointegration } & & \end{array}$

reg ROIL ROIL(2 lags) $\operatorname{RJPY(2} 0$

.25 JPY/USD does not Granger cause

lags), robust

reg ROIL ROIL(2 lags), robust

(.78) oil price

reg RJPY RJPY(2 lags) ROIL(2 0

.12 Oil price does not Granger cause lags),robust JPY/USD

reg RJPY RJPY(2 lags), robust

reg ROIL ROIL(3 lags) RMXN(3 0

lags), robust

reg ROIL ROIL(3 lags), robust

4.47*** MXN/USD Granger causes oil (.00) prices

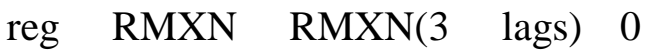

2.04 Oil prices does not Granger cause

ROIL(3 lags), robust

MXN/USD

regress RMXN RMXN(3 lags),

robust

reg ROIL ROIL(2 lags) $\mathrm{RNOK}(2 \quad 0$

lags), robust

4.95*** NOK/USD Granger causes oil prices

reg ROIL ROIL(2 lags), robust

reg RNOK RNOK(2 lags) ROIL(2 0

.19 Oil prices does not Granger cause

lags),robust

(.83) NOK/USD

reg RNOK RNOK(2 lags), robust

reg ROIL ROIL(2 lags) $\operatorname{RUK}(2 \quad 0$

1.33 UK/USD does not Granger causes

lags), robust

(.27) oil prices.

reg ROIL ROIL(2 lags), robust

reg RUK RUK(2 lags) ROIL(2 0

$3.53 * * \quad$ Oil prices Granger cause UK/USD

lags), robust

reg RUK RUK(2 lags), robust

Note: VAR model is used for causality tests. P-values are presented in parenthesis. $* \mathrm{p}<.05, * * \mathrm{p}<.01, * * * \mathrm{p}<.001$ 
Table 17: Granger causality and long-run test results for daily AUD/USD, CAD/USD, EUR/USD and NOK/USD with oil prices.

\begin{tabular}{|c|c|c|c|c|c|}
\hline & $\begin{array}{l}\# \text { of } \\
\text { lags }\end{array}$ & $\begin{array}{l}\# \text { of } \\
\text { cointegration }\end{array}$ & $\delta$ & $\begin{array}{l}\alpha \\
\text { chi2 } \\
(5 \%)\end{array}$ & conclusion \\
\hline $\begin{array}{l}\text { 1OIL } \\
\text { 1AUD }\end{array}$ & 6 & 1 & $\begin{array}{l}-.02 * * * \\
(.00)\end{array}$ & $\begin{array}{l}9.48 \\
(.09)\end{array}$ & $\begin{array}{l}\text { AUD/USD does not Granger causes } \\
\text { oil prices. } \\
\text { Oil prices Granger cause AUD/USD. }\end{array}$ \\
\hline 1AUD 1OIL & 6 & 1 & $\begin{array}{l}.00 \\
(.70)\end{array}$ & $\begin{array}{l}12.05 * * \\
(.03)\end{array}$ & $\begin{array}{l}\text { Oil prices adjusts back to equilibrium } \\
\text { when deviation occurs and } \\
\text { AUD/USD is leader. }\end{array}$ \\
\hline $\begin{array}{l}\text { 1OIL } \\
\text { 1CAD }\end{array}$ & 6 & 1 & $\begin{array}{l}-.04 * * * \\
(.00)\end{array}$ & $\begin{array}{l}17.53 * * * \\
(.00)\end{array}$ & $\begin{array}{l}\mathrm{CAD} / \mathrm{USD} \text { Granger causes oil prices. } \\
\text { Oil prices Granger causes } \\
\text { CAD/USD. }\end{array}$ \\
\hline 1CAD 1OIL & 6 & 1 & $\begin{array}{l}-.00 \\
(.99)\end{array}$ & $\begin{array}{l}24.92 * * * \\
(.00)\end{array}$ & $\begin{array}{l}\text { Oil prices adjusts back to equilibrium } \\
\text { when deviation occurs and } \\
\text { CAD/USD is leader }\end{array}$ \\
\hline 1OIL IEUR & 2 & 1 & $\begin{array}{l}-.01 * * * \\
(.00)\end{array}$ & $\begin{array}{l}1.32 \\
(.25)\end{array}$ & $\begin{array}{l}\text { EUR/USD does not Granger cause } \\
\text { oil prices. } \\
\text { Oil prices does not Granger cause }\end{array}$ \\
\hline lEUR 1OIL & 2 & 1 & $\begin{array}{l}-.00 \\
(.62)\end{array}$ & $\begin{array}{l}2.42 \\
(.12)\end{array}$ & $\begin{array}{l}\text { EUR/USD. } \\
\text { Oil prices adjusts back to equilibrium } \\
\text { when deviation occurs and } \\
\text { EUR/USD is leader }\end{array}$ \\
\hline $\begin{array}{l}\text { 1OIL } \\
1 \mathrm{NOK}\end{array}$ & 6 & 1 & $\begin{array}{l}-.01 * * * \\
(.00)\end{array}$ & $\begin{array}{l}14.35^{* * *} \\
(0.01)\end{array}$ & $\begin{array}{l}\text { NOK/USD Granger causes oil prices. } \\
\text { Oil prices Granger causes } \\
\text { NOK/USD. }\end{array}$ \\
\hline 1NOK 1OIL & 6 & 1 & $\begin{array}{l}.00 \\
(.40)\end{array}$ & $\begin{array}{l}36.51 * * * \\
(0.00)\end{array}$ & $\begin{array}{l}\text { Oil prices adjusts back to equilibrium } \\
\text { when deviation occurs and } \\
\text { NOK/USD is leader }\end{array}$ \\
\hline
\end{tabular}

NOTE: VECM is conducted. P-values are presented in parenthesis. ${ }^{*} \mathrm{p}<.05,{ }^{*} \mathrm{p}<.01, * * * \mathrm{p}<.001$ 
Table 18: Granger causality and long-run test results for weekly AUD/USD, CAD/USD, EUR/USD and NOK/USD with oil prices.

\begin{tabular}{|c|c|c|c|c|c|}
\hline & $\begin{array}{l}\# \text { o } \\
\text { lags }\end{array}$ & $\begin{array}{l}\text { f } \# \text { of } \\
\text { cointegration }\end{array}$ & $\bar{\delta}$ & $\alpha$ & conclusion \\
\hline $\begin{array}{l}\text { lOIL } \\
1 \text { AUD }\end{array}$ & 2 & 1 & $\begin{array}{l}-.08^{* * * *} \\
(.00)\end{array}$ & $\begin{array}{l}.09 \\
(.76)\end{array}$ & $\begin{array}{l}\text { AUD/USD does not Granger cause oil } \\
\text { prices. } \\
\text { Oil prices does not Granger cause }\end{array}$ \\
\hline 1AUD 1OIL & 2 & 1 & $\begin{array}{l}.00 \\
(.74)\end{array}$ & $\begin{array}{l}.32 \\
(.57)\end{array}$ & $\begin{array}{l}\text { AUD/USD. } \\
\text { Oil prices adjusts back to equilibrium when } \\
\text { deviation occurs and AUD/USD is leader. }\end{array}$ \\
\hline $\begin{array}{l}\text { lOIL } \\
1 \mathrm{CAD}\end{array}$ & 3 & 1 & $\begin{array}{l}-.14 * * * \\
(.00)\end{array}$ & $\begin{array}{l}2.86 \\
(.24)\end{array}$ & $\begin{array}{l}\text { CAD/USD does not Granger cause oil } \\
\text { prices. } \\
\text { Oil prices does not Granger cause }\end{array}$ \\
\hline 1CAD 1OIL & 3 & 1 & $\begin{array}{l}.00 \\
(.59)\end{array}$ & $\begin{array}{l}4.82 \\
* \\
(.09)\end{array}$ & $\begin{array}{l}\text { CAD/USD. } \\
\text { Oil prices adjusts back to equilibrium when } \\
\text { deviation occurs and CAD/USD is leader }\end{array}$ \\
\hline 1OIL IEUR & 4 & 1 & $\begin{array}{l}-.05 * * * \\
(.00)\end{array}$ & $\begin{array}{l}6.08 \\
(.11)\end{array}$ & $\begin{array}{l}\text { EUR/USD does not Granger cause oil } \\
\text { prices. } \\
\text { Oil prices does not Granger cause }\end{array}$ \\
\hline 1EUR 1OIL & 4 & 1 & $\begin{array}{l}-.00 \\
(.66)\end{array}$ & $\begin{array}{l}2.01 \\
(.57)\end{array}$ & EUR/USD. \\
\hline & & & & & $\begin{array}{l}\text { Oil prices adjusts back to equilibrium when } \\
\text { deviation occurs and EUR/USD is leader }\end{array}$ \\
\hline $\begin{array}{l}\text { 1OIL } \\
1 \mathrm{NOK}\end{array}$ & 3 & 1 & $\begin{array}{l}-.05^{* * * *} \\
(.00)\end{array}$ & $\begin{array}{l}2.14 \\
(.34)\end{array}$ & $\begin{array}{l}\text { NOK/USD does not Granger cause oil } \\
\text { prices. } \\
\text { Oil prices does not Granger cause }\end{array}$ \\
\hline INOK IOIL & 3 & 1 & $\begin{array}{l}.00 \\
(.22)\end{array}$ & $\begin{array}{l}.77 \\
(.68)\end{array}$ & $\begin{array}{l}\text { NOK/USD. } \\
\text { Oil prices adjusts back to equilibrium when } \\
\text { deviation occurs and NOK/USD is leader }\end{array}$ \\
\hline
\end{tabular}


Table 19: Granger causality and long-run test results for monthly AUD/USD, CAD/USD, and EUR/USD with oil prices.

\begin{tabular}{|c|c|c|c|c|c|}
\hline & $\begin{array}{l}\# \text { of } \\
\text { lags }\end{array}$ & $\begin{array}{l}\# \text { of } \\
\text { cointegration }\end{array}$ & $\delta$ & $\begin{array}{l}\alpha \\
\text { chi2 } \\
(5 \%)\end{array}$ & conclusion \\
\hline $\begin{array}{l}\text { 1OIL } \\
\text { 1AUD }\end{array}$ & 3 & 1 & $\begin{array}{l}-.27 * * * \\
(.00)\end{array}$ & $\begin{array}{l}2.81 \\
(.24)\end{array}$ & $\begin{array}{l}\text { AUD/USD does not Granger causes } \\
\text { oil prices. } \\
\text { Oil prices does not Granger cause }\end{array}$ \\
\hline 1AUD IOIL & 3 & 1 & $\begin{array}{l}.00 \\
(.69)\end{array}$ & $\begin{array}{l}1.81 \\
(.40)\end{array}$ & $\begin{array}{l}\text { AUD/USD. } \\
\text { Oil prices adjusts back to equilibrium } \\
\text { when deviation occurs and AUD/USD } \\
\text { is leader. }\end{array}$ \\
\hline $\begin{array}{l}\text { 1OIL } \\
1 \mathrm{CAD}\end{array}$ & 6 & 1 & $\begin{array}{l}-.85^{* * * *} \\
(.00)\end{array}$ & $\begin{array}{l}15.91^{*} \\
* * \\
(.00)\end{array}$ & $\begin{array}{l}\text { CAD/USD Granger causes oil prices. } \\
\text { Oil prices does not Granger causes } \\
\text { CAD/USD. }\end{array}$ \\
\hline 1CAD IOIL & 6 & 1 & $\begin{array}{l}-.06 \\
(.11)\end{array}$ & $\begin{array}{c}7.76 \\
(.17)\end{array}$ & $\begin{array}{l}\text { Oil prices adjusts back to equilibrium } \\
\text { when deviation occurs and CAD/USD } \\
\text { is leader }\end{array}$ \\
\hline 1OIL IEUR & 2 & 1 & $\begin{array}{l}-.25 * * * \\
(.00)\end{array}$ & $\begin{array}{l}.39 \\
(.53)\end{array}$ & $\begin{array}{l}\text { EUR/USD does not Granger cause oil } \\
\text { prices. } \\
\text { Oil prices does not Granger cause }\end{array}$ \\
\hline 1EUR 1OIL & 2 & 1 & $\begin{array}{l}-.00 \\
(.73)\end{array}$ & $.8735)$ & EUR/USD. \\
\hline & & & & & $\begin{array}{l}\text { Oil prices adjusts back to equilibrium } \\
\text { when deviation occurs and EUR/USD } \\
\text { is leader }\end{array}$ \\
\hline
\end{tabular}

NOTE: VECM is conducted. P-values are presented in parenthesis. ${ }^{*} \mathrm{p}<.05,{ }^{* *} \mathrm{p}<.01,{ }^{* * *} \mathrm{p}<.001$ 
Table 20: Summary of Results

\begin{tabular}{|c|c|c|c|c|c|c|c|c|}
\hline & & $\begin{array}{l}\text { AUD/ } \\
\text { USD }\end{array}$ & $\begin{array}{l}\text { CAD/ } \\
\text { USD }\end{array}$ & $\begin{array}{l}\text { EUR/ } \\
\text { USD }\end{array}$ & $\begin{array}{l}\text { JPY/ } \\
\text { USD }\end{array}$ & $\begin{array}{l}\text { MXN/ } \\
\text { USD }\end{array}$ & $\begin{array}{l}\text { NOK/ } \\
\text { USD }\end{array}$ & $\begin{array}{l}\text { GBT/ } \\
\text { USD }\end{array}$ \\
\hline \multirow[t]{2}{*}{ daily } & cointegrated & 1 & 1 & 1 & 0 & 0 & 1 & 0 \\
\hline & causality & $\begin{array}{l}\text { Uni-dir } \\
\text { oil } \Rightarrow\end{array}$ & $\stackrel{\text { bi-dir }}{\Leftrightarrow}$ & indep & indep & indep & bi-dir & indep \\
\hline \multirow[t]{2}{*}{ weekly } & cointegrated & 1 & 1 & 1 & 0 & 0 & 1 & 0 \\
\hline & causality & indep & indep & indep & indep & indep & indep & indep \\
\hline \multirow[t]{2}{*}{ monthly } & cointegrated & 1 & 1 & 1 & 0 & 0 & 0 & 0 \\
\hline & causality & indep & $\begin{array}{l}\text { Uni-dir } \\
\text { CAD } \Rightarrow\end{array}$ & indep & indep & $\begin{array}{l}\text { Uni-dir } \\
\text { MXN } \Rightarrow\end{array}$ & $\begin{array}{l}\text { Uni-dir } \\
\text { NOK } \Rightarrow\end{array}$ & $\begin{array}{l}\text { Uni-dir } \\
\text { oil } \Rightarrow\end{array}$ \\
\hline
\end{tabular}

